\title{
Colombia: Financial System Stability Assessment
}

This paper on Colombia was prepared by a staff team of the International Monetary Fund as background documentation for the periodic consultation with the member country. It is based on the information available at the time it was completed on January 9, 2013. The views expressed in this document are those of the staff team and do not necessarily reflect the views of the government of Colombia or the Executive Board of the IMF.

The policy of publication of staff reports and other documents by the IMF allows for the deletion of market-sensitive information.

\author{
Copies of this report are available to the public from \\ International Monetary Fund • Publication Services \\ $70019^{\text {th }}$ Street, N.W. • Washington, D.C. 20431 \\ Telephone: (202) 623-7430 • Telefax: (202) 623-7201 \\ E-mail: publications@imf.org Internet: http://www.imf.org
}

\section{International Monetary Fund Washington, D.C.}




\title{
INTERNATIONAL MONETARY FUND
}

\section{COLOMBIA}

\section{Financial System Stability Assessment}

\author{
Prepared by the Monetary and Capital Markets and Western Hemisphere Departments
}

\author{
Approved by J. Viñals and S. Lizondo
}

January 9, 2013

This report is based on the work of a joint IMF-World Bank Financial Sector Assessment Program (FSAP) missions to Colombia during May 22-June 4, 2012 and July 9-18, 2012. The team comprised Robert Rennhack (head of mission, IMF), Mariano Cortes and Eva Gutierrez (heads of mission, World Bank), William Allen (consultant), Michel Canta (consultant), Andrea Corcoran (consultant), Teresa Daban-Sanchez, Socorro Heysen (consultant), Emanuel Kopp, Ryan Scuzzarella, and Torsten Wezel (IMF), Catiana Garcia-Kilroy, Jose Antonio Garcia Luna, Charles Michael Grist, Ignacio Mas (consultant), Heinz Rudolf, and Valeria Salomao Garcia.

- $\quad$ Colombia has a broad financial system, dominated by complex financial conglomerates and with a variety of intermediaries. The financial health of credit institutions appears sound, with healthy balance sheet of corporate and households, strong credit quality, and profitable banks. Nonbank financial intermediaries generally have been performing well.

- The main risk for the financial sector is the possibility of a protracted global recession that would cut domestic economic growth and weaken the quality of the loan portfolio. However, the direct effect of deleveraging in Europe would probably have little effect on Colombia's banking system. Another potential vulnerability includes the pace of expansion in bank credit. The stress tests underscore that Colombian banks appear resilient to a variety of shocks, although the high concentration of commercial loans does pose more significant risks.

- $\quad$ All financial institutions are supervised effectively by the Financial Superintendency of Colombia (SFC). The broad authority of the SFC, while presenting some organizational challenges, offers several key benefits, including the ability to develop a common supervisory framework for the financial sector, secure information on financial groups, and contain regulatory arbitrage. Because of the broad regulatory perimeter, there are several critical supervisory issues that apply to all financial institutions, especially enhancing the de jure independence of the SFC, adopting a law to extend full supervisory and regulatory powers to holding companies of financial institutions, and strengthen supervision of broker-dealers and collective investment schemes.

- $\quad$ The financial safety net provides adequate safeguards, although it could be enhanced. Overall, liquidity flows through the Colombian financial system fairly smoothly, deposit insurance is effective, and the authorities can employ a wide range of bank resolution tools. However, the authorities could adopt several steps to foster a deeper interbank money market, and it would be advisable to tighten supervision of broker-dealers and other NBFIs, especially in the area of liquidity management. It would also be important to strengthen several aspects of the resolution framework.

FSAP assessments are designed to assess the stability of the financial system as a whole and not that of individual institutions. They have been developed to help countries identify and remedy weaknesses in their financial sector structure, thereby enhancing their resilience to macroeconomic shocks and cross-border contagion. FSAP assessments do not cover risks that are specific to individual institutions such as asset quality, operational or legal risks, or fraud. 
Acronyms .4

Executive Summary. .5

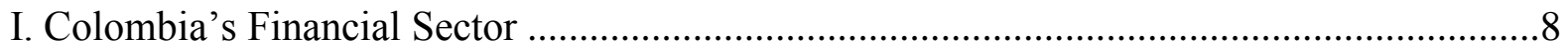

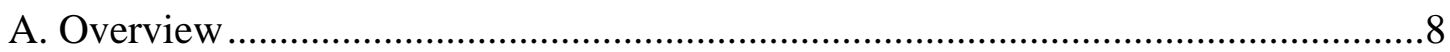

B. Key Macro-Financial Risks for Banking System.............................................. 12

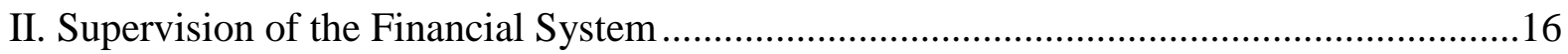

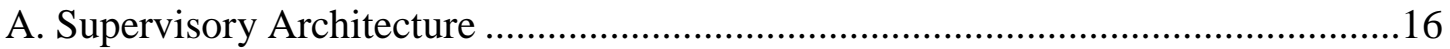

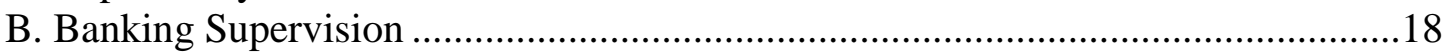

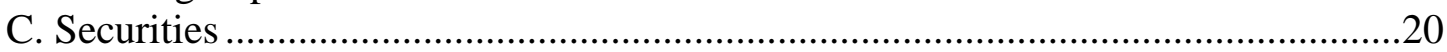

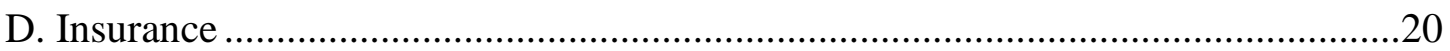

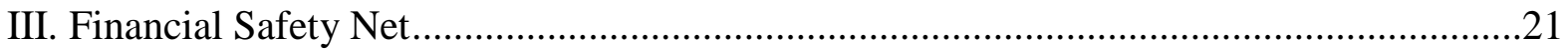

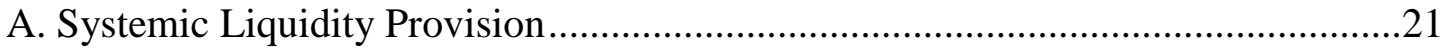

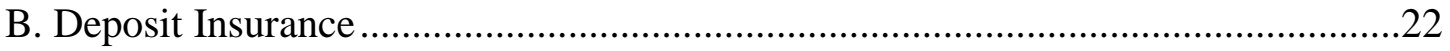

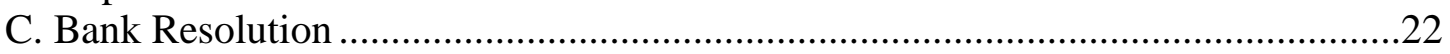

IV. Financial Stability and Macroprudential Framework ..............................................23

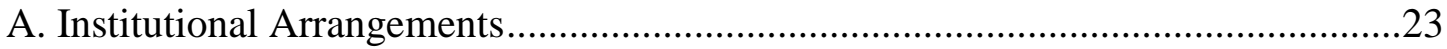

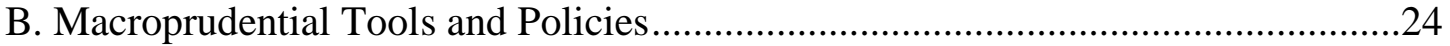

Tables

1. Financial Sector Assessment Program Key Recommendations .....................................7

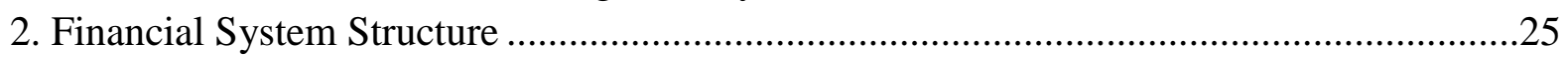

3. Selected Economic and Financial Indicators ..............................................................26

4. Summary Compliance with the Basel Core Principles-Detailed Assessments .................39

5. Recommended Action Plan to Improve Compliance with the Basel Core Principles .........41

6. Summary Implementation of the IOSCO Principles ................................................49

7. Summary of Observance of the Insurance Core Principles .............................................76

8. Recommendations to Improve Observance of ICPs ..................................................81

Figures

1. Structure of Colombia's Financial System ..................................................................

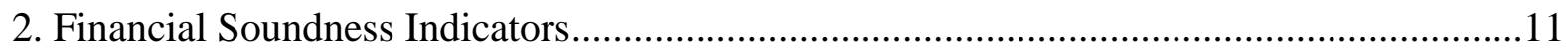

3. Private Sector Exposure to Foreign Financing …..................................................... 12

4. Credit Growth and Credit Composition ...................................................................... 13

5. Indices of Prices of Equities and Existing Houses..................................................... 14 
Appendices

I. Risk Assessment Matrix .27

II. Stress Test Matrix for Solvency Risk.

III. Stress Test Matrix for Liquidity Risk

Annexes

I. Basel Core Principles-Summary Assessment..... 32

II. IOSCO Principles-Summary Assessment .46

III. Insurance Core Principles (ICPs)—Summary Assessment .63 


\section{ACRONYMS}

AML/CFT

AMV

BR

BVC

CAR

CCDC

CCSSF

CRCC

DCV

DECEVAL

FOGAFIN

FSAP

GAAP

GDP

IAIS

IFRS

IOSCO

IRA

LCR

LR

LRI

LTV

MHCP

MILA

MIS

MOU

NPL

NAV

NSFR

ROA

ROE

RTGS

RWA

SARs

SFC

TES

URF
Anti-Money Laundering/Combatting the Financing of Terrorism

Self-Regulator of Securities Markets in Colombia

Banco de la Republica

Stock Exchange of Colombia

Capital Adequacy Ratio

Foreign Exchange Clearing House of Colombia

Financial System Monitoring Committee

Central Counterparty Risk Board

Central Securities Depository

Centralized Securities Depository of Colombia

Guarantee Fund for Financial Institutions

Financial Sector Assessment Program

Generally Accepted Accounting Principles

Gross Domestic Product

International Association of Insurance Supervisors

International Financial Reporting Standards

International Organization of Securities Commissions

Individual Retirement Account

Liquidity Coverage Ratio

Liquidity Ratio

Liquidity Risk Index

Loan-to-Value

Ministry of Finance and Public Credit

Integrated Latin American Market

Integrated Supervisory Framework

Memorandum Of Understanding

Nonperforming Loan

Net Asset Value

Net Stable Funding Ratio

Return on Assets

Return on Equity

Real time gross settlement systems

Risk Weighted Assets

Risk Administration Systems

Financial Superintendency of Colombia

Treasury Bonds

Financial Regulation Unit 


\section{EXECUTIVE SUMMARY}

Colombia has a broad financial system, dominated by complex financial conglomerates and with a variety of intermediaries. Assets of the supervised financial system reached about 90 percent of GDP at end-2011. Credit institutions (mostly banks) account for about half of financial system assets, with the balance held by nonbanks (largely private pension funds, trust companies and insurance companies). Large domestic complex conglomerates dominate the financial landscape, with ten holding about 80 percent of total financial sector assets. Colombia's capital markets reflect mainly activity in government debt and equity markets, with equity market capitalization reaching 60 percent of GDP at end-2011.

The financial health of credit institutions appears sound. Credit quality is strong and banks are quite profitable, largely because the borrowers from credit institutions have healthy balance sheets. Funding is stable, relying mostly on customer deposits and only minimally on short-term wholesale funding. At end-March 2012, the capital adequacy ratio (CAR) was 15.3 percent (regulatory minimum of 9 percent). In August 2012, the authorities issued a decree to phase in by August 2013 a new capital adequacy regime that significantly enhances the loss-absorbing capacity of bank capital.

Nonbank financial intermediaries generally have been performing well. Assets of the fully-funded private pension system reached almost 20 percent of GDP by June 2012, and over the past 5 years, the private pension funds have earned an average nominal return of 13 percent. Trust companies account for an equivalent share of financial system assets and comprise a wide range of institutions, including pension funds for unionized employees and mutual funds. Other nonbank financial intermediaries, including insurance companies, broker-dealers and investment administrators, hold a small share of financial system assets.

The main risk for the financial sector is the possibility of a protracted global recession that would cut economic growth and weaken the quality of the loan portfolio. However, the direct effect of deleveraging in Europe would probably have little effect on Colombia's banking system. Another important potential source of domestic vulnerability could be the pace of expansion in bank credit, although these risks are mitigated by the strength of household and corporate balance sheets as well as the system's limited exposure to currency risk. There are few signs of asset bubbles in equity or housing prices, but the lack of depth and liquidity in key asset markets calls for continued vigilance.

Colombian banks appear resilient to a variety of shocks. Their substantial net interest income serves as solid cushion against the effects of losses related to credit risk, while their reliance on stable deposits for funding helps guard against liquidity shocks. The effect of market risk is contained by the low share of bank assets invested in fixed income assets. Banks maintain small exposures in the interbank market, keeping contagion risk quite low. However, more significant risks do arise from the high concentration of the commercial loan portfolio. 
All financial institutions are supervised effectively by the Financial Superintendency of Colombia (SFC). The broad authority of the SFC offers several critical benefits, including the ability to develop a common supervisory framework for the financial sector, secure information on financial groups, and contain regulatory arbitrage. Because of the broad regulatory perimeter, there are several critical supervisory issues that apply to all financial institutions. In particular, the SFC has considerable de facto independence to undertake operations required by its mandates, and the supervisor carries out his functions with no political interference. However, its de jure independence could be strengthened. The SFC would benefit from legal reform to extend its full regulatory and supervisory powers to holding companies of financial institutions.

The SFC exercises effective oversight of the banking system and is strengthening supervision further to fully implement a comprehensive risk management framework. It enforces a robust framework for assessment of credit risk and asset classification and provisioning, and ensures that banks adopt prudent management of market, liquidity and operational risks. The authorization processes are thorough, including licensing, transfers of ownership and investments. The new capital regime represents an important step forward from the outgoing capital adequacy rules. The consolidated supervision of financial conglomerates has been significantly enhanced since the creation of the SFC in 2005, although it would benefit from broader legal authority in this area, especially to oversee currently unregulated bank holding companies and to force changes in a group's structure. Large exposure limits are in place but need to be more comprehensive and streamlined to help manage concentration risk and related party lending limits need to be strengthened to further control connected lending. Going forward, the SFC would also benefit from a Basel II, Pillar 2 supervisory framework to give the SFC explicit authority to tailor prudential norms to the risk profile of each financial institution.

The financial safety net provides adequate safeguards, although it could be enhanced. Overall, liquidity flows through the Colombian financial system fairly smoothly, deposit insurance is effective, and the authorities can employ a wide range of bank resolution tools. However, the authorities could adopt several steps to foster a deeper interbank money market, and it would be advisable to tighten supervision of broker-dealers and other NBFIs, especially in the area of liquidity management. It would also be important to separate the resolution tools into those appropriate for systemic threats and those for non-systemic problems and to shorten the time of possession of an intervened institution.

\section{Crisis management and macroprudential policy coordination is handled through the} Financial Stability Monitoring Committee. This committee works well but would benefit from a greater degree of formality, especially through the introduction of a strategic action plan for dealing with systemic risk that respects the legal mandates of each institution and establishes a clear process for decision making. Going forward, the authorities might want to consider phasing in countercyclical capital buffers to address systemic shocks, but it would be crucial to understand how such a system would dovetail with the current system of countercyclical loan loss provisioning. 
Table 1. Colombia: Financial Sector Assessment Program Key Recommendations

\begin{tabular}{|c|c|c|c|}
\hline Recommendations & Institution/s & Priority & Horizon \\
\hline \multicolumn{4}{|l|}{ Independence of SFC } \\
\hline $\begin{array}{l}\text { Include the requirement to appoint the superintendent for a fixed } \\
\text { term or to require a public explanation of the reasons for dismissal. }\end{array}$ & MHCP & High & ST \\
\hline \multicolumn{4}{|l|}{ Legal Protection } \\
\hline $\begin{array}{l}\text { Amend legal framework to clarify that liability for failure to perform } \\
\text { the regulatory mandate in good faith should be defined as } \\
\text { equivalent to acting in bad faith; and that the judicial authorities can } \\
\text { limit circumstances in which private parties can sue. }\end{array}$ & MHCP & Medium & MT \\
\hline \multicolumn{4}{|l|}{ Holding Companies of Financial Conglomerates } \\
\hline $\begin{array}{l}\text { Approve law that gives SFC supervisory and regulatory powers } \\
\text { over the holding company of a financial conglomerate. }\end{array}$ & MHCP & High & MT \\
\hline \multicolumn{4}{|l|}{ Adoption of International Financial Reporting Standards } \\
\hline Continue implementation of IFRS & SFC & Medium & MT \\
\hline \multicolumn{4}{|l|}{ Standards for External Auditors } \\
\hline Publish timetable to comply with international auditing standards. & SFC & Medium & MT \\
\hline \multicolumn{4}{|l|}{ Bank Regulation } \\
\hline Adopt Basel II, Pillar 2 supervisory framework. & MHCP & High & MT \\
\hline $\begin{array}{l}\text { Introduce specifications for comprehensive risk management of } \\
\text { banks and banking groups. }\end{array}$ & SFC & High & MT \\
\hline $\begin{array}{l}\text { Formulate guidelines to undertake ICAAP reviews both at individual } \\
\text { bank and conglomerate level. }\end{array}$ & SFC & High & MT \\
\hline $\begin{array}{l}\text { Simplify large exposure limits by reducing number of separate } \\
\text { limits as well as the range of exceptions to help manage } \\
\text { concentration risk. }\end{array}$ & SFC & High & MT \\
\hline Ensure that limit on related-party lending cover all such exposures. & SFC & High & MT \\
\hline \multicolumn{4}{|l|}{ Securities Regulation } \\
\hline $\begin{array}{l}\text { Require earlier notification of public meetings and extraordinary } \\
\text { actions to improve protections for minority shareholders }\end{array}$ & SFC & Medium & ST \\
\hline $\begin{array}{l}\text { Tighten oversight of broker dealers and other collective investment } \\
\text { schemes. }\end{array}$ & SFC & Medium & MT \\
\hline \multicolumn{4}{|l|}{ Bank Resolution Framework } \\
\hline $\begin{array}{l}\text { Reform legal framework to shorten period of possession and limit } \\
\text { reliance on options inconsistent with accepted resolution principles }\end{array}$ & MHCP, SFC & Medium & MT \\
\hline \multicolumn{4}{|l|}{ Macroprudential Policy } \\
\hline $\begin{array}{l}\text { Adopt more formal structure of CCSSF through adoption of action } \\
\text { plan to manage a systemic crisis. }\end{array}$ & $\begin{array}{l}\mathrm{MHCP}, \mathrm{SFC} \\
\text { and BR }\end{array}$ & Medium & MT \\
\hline \multicolumn{4}{|l|}{ Money Markets } \\
\hline Phase out the financial transaction tax faster than currently planned & MHCP & Medium & MT \\
\hline Expand issuance of short-term government securities & MHCP & Medium & MT \\
\hline Narrow range of counterparties in open market operations & $\mathrm{BR}$ & Medium & MT \\
\hline \multicolumn{4}{|l|}{ Liquidity Management } \\
\hline Tighten liquidity standards for broker-dealers and other NBFIs & MHCP & High & MT \\
\hline $\begin{array}{l}\text { Adopt more rigorous stress testing of broker-dealers and other } \\
\text { NBFls. }\end{array}$ & MHCP & High & MT \\
\hline
\end{tabular}




\section{COlombia's Financial Sector}

\section{A. Overview}

\section{Colombia has a broad financial system, dominated by complex financial} conglomerates and with a variety of intermediaries (Figure 1, Table 2). Over the past decade, assets of the supervised financial system have risen from about 60 percent of GDP in 2000 to about 90 percent of GDP in 2011. Credit institutions (mostly banks) account for about half of financial system assets, with the balance held by nonbanks (largely private pension funds, trust companies and insurance companies). Large domestic complex conglomerates dominate the financial landscape, with ten holding about 80 percent of total financial sector assets. In the banking sector, the top 3 banks (Bancolombia S.A., Banco de Bogota S.A., and Davivienda S.A) hold about 60 percent of banking system assets, ${ }^{1}$ and banks extend 90 percent of their commercial loans to 7 percent of debtors. Also, only one-third of the population has access to the banking system, reflecting in part the large informal sector. This underscores the importance of measures to broaden access to financial services, which would contribute to a more diversified financial system.

Figure 1. Colombia: Structure of Colombia's Financial System
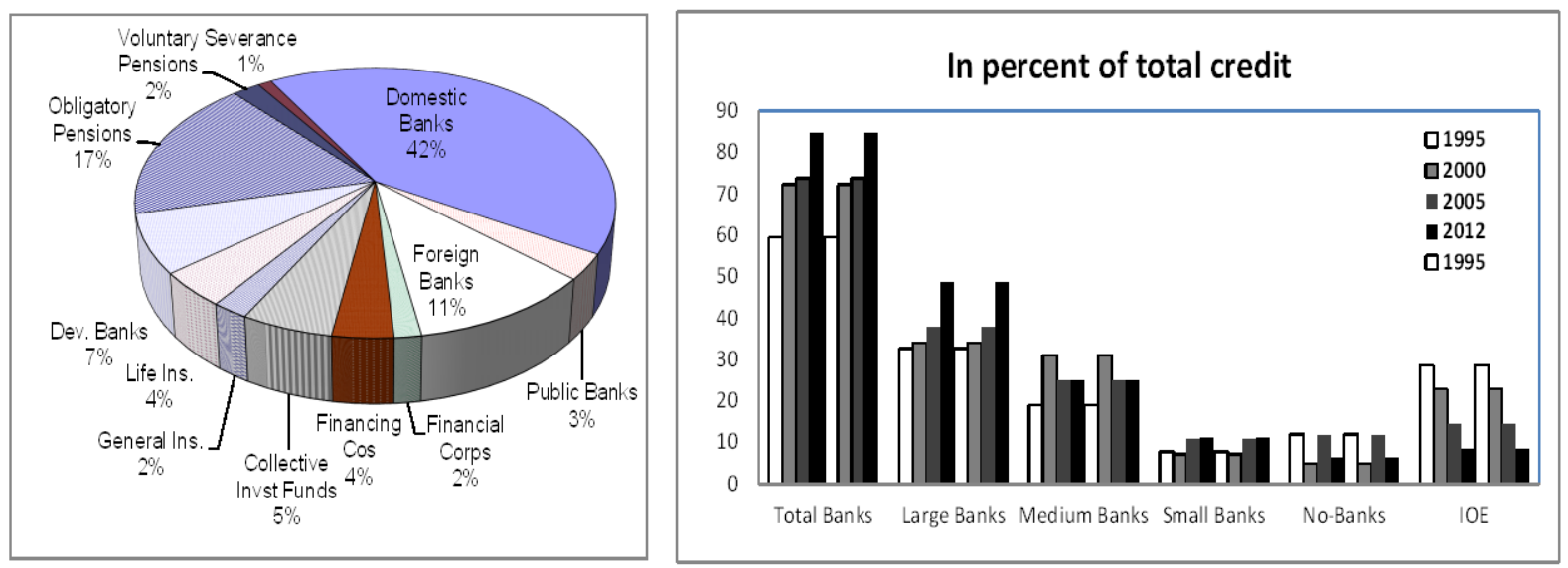

Source: Colombian authorities \& IMF staff estimates.

2. Colombia's capital markets reflect mainly activity in government debt and equity markets, with capitalization reaching 60 percent of GDP at end-2011. Non-government fixed income remains undeveloped (4 percent of GDP) and dominated by financial sector issues. The investor base comprises mainly domestic investors - the compulsory individual capitalization pension funds (20 percent of GDP), insurance companies (4 percent of GDP) and mutual funds (5 percent of GDP). Financial development is broadly in line with the region and the country's characteristics.

\footnotetext{
${ }^{1}$ This treats the four banks owned by Grupo Aval as one bank.
} 
3. The financial health of credit institutions appears sound. ${ }^{2}$ At end-March 2012, roughly half of their assets were loans to the corporate sector, another third lending to households. One fifth of their assets were claims on government-mostly holdings of government securities. These assets were funded primarily through customer deposits (64 percent of assets), bonds and commercial paper of more than one-year maturity ( 7 percent of assets) and equity (13 percent). Short-term wholesale funding is equivalent to 11 percent of assets. At end-March 2012, the regulatory capital adequacy ratio (CAR) was 15.3 percent (minimum of 9 percent), with a Tier 1 ratio of 12.5 percent. ${ }^{3}$ However, this measure includes the value of goodwill, and the CAR excluding the value of goodwill was 14.3 percent.

\section{In August 2012, the authorities issued a decree to phase in by August 2013 a new} capital adequacy regime that enhances the loss-absorbing capacity of bank capital. Under the outgoing regime, regulatory capital includes the value of goodwill, all voluntary reserves and investments in unsupervised bank holding companies. The new capital regime retains the minimum CAR of 9 percent and sets a new minimum of 4.5 percent for Tier 1 capital. It also excludes newly-generated goodwill, while grandfathering existing goodwill (which will be fully amortized over the next 14 years). It recognizes voluntary reserves as part of Tier 2 capital up to a limit of 10 percent of total regulatory capital. Also deferred tax assets and pension liabilities will be deducted from regulatory capital. Risk weights will continue to be broadly in line with the Basel I capital framework. Under the new regime (with the assumption that all existing voluntary reserves are declared permanent and excluding all goodwill), it is estimated that the system-wide CAR would have declined to 13.7 percent as of March 2012 (Tier 1 capital of 8.1 percent).

5. The borrowers from credit institutions have healthy balance sheets. As of end-2010, the estimated net worth of the corporate sector was 65 percent of GDP, with total liabilities of 35 percent of GDP. This sector's exposure to the financial sector amounted to about 16 percent of GDP, and its liquid assets were well in excess of its short-term liabilities. The corporate sector has very little exposure to external debt, although the mining and transport sectors rely more on external borrowing. Gross household debt amounted to only 13 percent of GDP as of June 2011, with debt service at 15 percent of salaries - all in local currency. Gross debt of the public sector stood at 34 percent of GDP at end-2011, and CDS spreads on sovereign debt have ranged between 100-200 basis points since 2006. Over the past several years, public debt management has lengthened the duration of public debt to 4.6 years and increased the share of debt in local currency to almost 75 percent.

\footnotetext{
${ }^{2}$ These institutions include 23 commercial banks, 4 financial corporations, 22 finance companies, 6 cooperatives and 11 special official financial institutions. The state plays a very small role in Colombia's financial system. Official financial institutions are second-tier banks and account for 7 percent of financial system assets.

${ }^{3}$ Colombia generally applies a Basel I capital standard, including an adjustment for market risk.
} 
6. Against this background, credit quality is strong and banks are quite profitable. Nonperforming loans (NPLs) were manageable at 2.8 percent of total loans at end-March 2012. ${ }^{4}$ NPL ratios varied by portfolio, with consumer and microfinance loans exhibiting slightly higher ratios at 4.8 and 4.5 percent, respectively, and commercial and housing at 1.8 and 2.5 percent, respectively. Provisions appear adequate, covering 163 percent of total NPLs (one fifth of the provisions come from the countercyclical loan loss provisioning system adopted in 2007). Since 2005 , the return on assets has fluctuated narrowly around 2 percent, and the return on equity has stayed near 26 percent, with profits arising mostly from a wide net intermediation margin. This strong profitability may reflect in part the concentration of the banking system, which can restrict competition and efficiency. Non-structural analyses using estimates of market power based on observed behavior by banks point to the presence of a degree of monopolistic competition similar to regional averages. ${ }^{5}$ Also administrative costs as a percentage of assets are higher than the regional median and the expected level given Colombia's level of development.

\section{The principal nonbank financial intermediaries are the private pension funds,} which manage IRA-type pensions with total assets equivalent to almost 20 percent of GDP. These funds hold the largest share of these assets in government securities, followed by corporate securities, foreign assets and to a much lesser extent deposits and equity in other financial institutions. Over the past 5 years, the private pension funds have earned an average nominal return of 13 percent. These private pension fund accounts co-exist with a public pay-asyou-go (PAYGO) system, and individuals may switch regimes once every five years, making their last choice ten years before retirement. This means that the risk of poor investment returns on pension funds tends to be borne by the government as well as those individuals who retire under the private system.

8. There are a wide range of other non-bank financial intermediaries. Trust companies comprise a wide range of institutions, including pension funds for unionized employees and mutual funds. Together their assets amounted to 20 percent of GDP at end-June 2012, with most of their investment in fixed-income local currency private instruments, public debt and to a lesser extent domestic equity. Assets of insurance companies amounted to 4 percent of GDP at endJune 2012, with about half of these held in government securities. By June 2012, the return on these assets rose to 3.0 percent, and the capital of insurance companies reached 13.8 percent. Other nonbank financial intermediaries include broker-dealers and investment administrators, and accounted for less than 1 percent of financial system assets at end-June 2012.

\footnotetext{
${ }^{4}$ In Colombia, loans that are 30 days or more past due are classified as non-performing.

${ }^{5}$ An estimate for the H-statistic was 0.78 for Colombia, similar to the regional average of 0.77 . The H-statistic equals 1 for perfect competition, less than or equal to 0 under a monopoly.
} 
Figure 2. Colombia: Financial Soundness Indicators
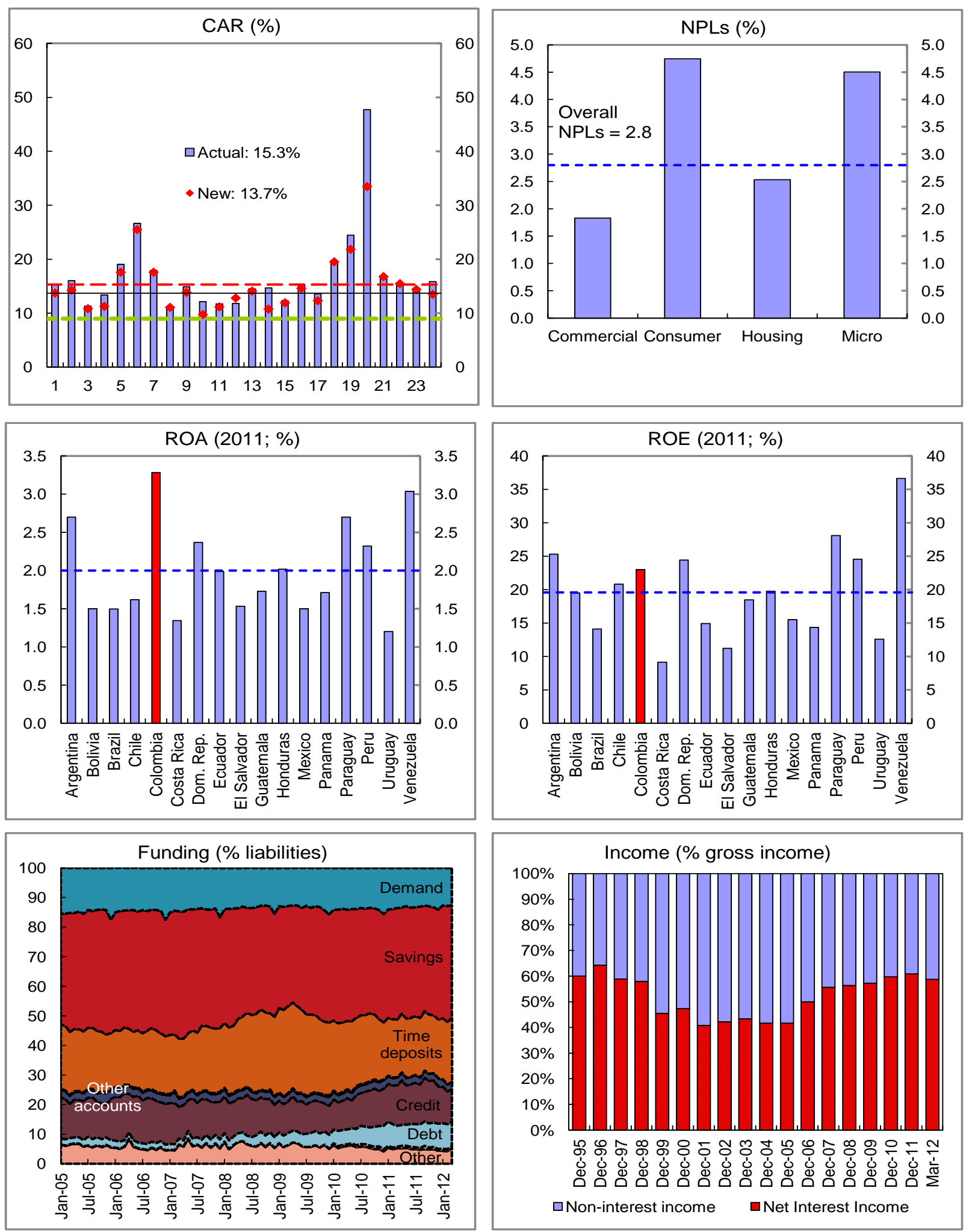

Sources: Colombian authorities \& IMF staff estimates. 


\section{B. Key Macro-Financial Risks for Banking System}

9. As explained in the companion Article IV consultation report, the economic outlook remains favorable (Table 3). Reflecting the normalization of macroeconomic policies after the crisis, growth over the medium term is projected to stay at about 4.5 percent, while inflation would remain in the central bank's 2-4 percent target range. Fiscal consolidation will continue under the recently approved fiscal rule. Colombia's current account deficit is projected to remain relatively low, financed by continued high FDI inflows.

\section{Global risks}

10. The main risk for the financial sector is the possibility of a protracted global recession that would cut economic growth and weaken the quality of the loan portfolio (Appendix I). Such a downturn could be fueled by adverse developments in Europe, a decline U.S. growth (Colombia's major trading partner) or a hard landing in China, and would slow Colombia's growth mainly by reducing commodity exports (about 80 percent of total merchandise exports), remittances or foreign direct investment. A sharp rise in global risk aversion could tighten financial conditions in Colombia through less access to external financing as well as through direct upward pressure on local funding costs.

Figure 3. Colombia: Private Sector Exposure to Foreign Financing

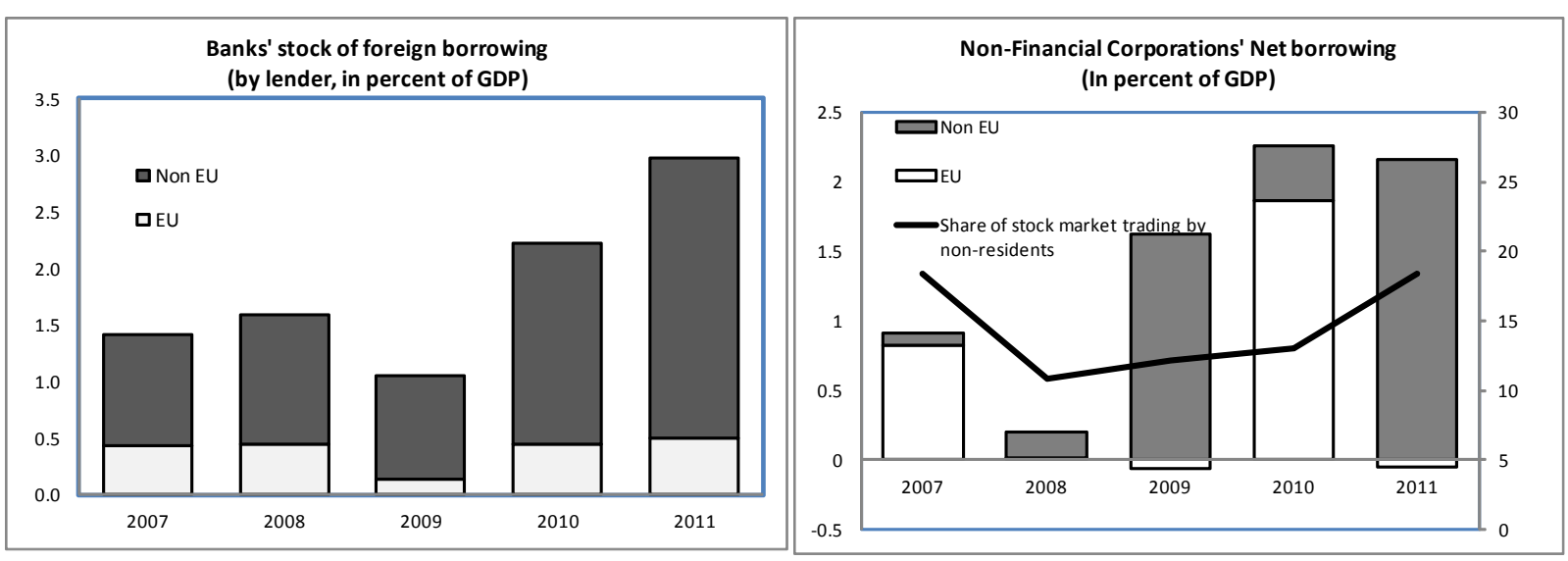

Sources: Colombian authorities and IMF staff's calculations.

11. However, the direct effect of deleveraging in Europe would probably have little effect on Colombia's banking system. Banks' outstanding borrowing from foreign sources accounts only for 2.5 percent of GDP. In Colombia, foreign banks have a small share of the financial market (19 percent of banking assets), well below most other countries in the region. The only two European banks operating in Colombia are BBVA - the fourth largest bank with 9 percent of banking system assets - and Santander - with just 3 percent of assets. In 2012, Santander sold 51 percent of its equity to Corbanco of Chile, with no impact on the domestic market. Both of these banks are subsidiaries that fund themselves almost entirely through domestic retail deposits. Foreign borrowing by either Colombian banks or non-financial 
corporations, either through cross-border banking loans or bonds, is small, especially from the Euro area.

Figure 4. Colombia: Credit Growth and Credit Composition
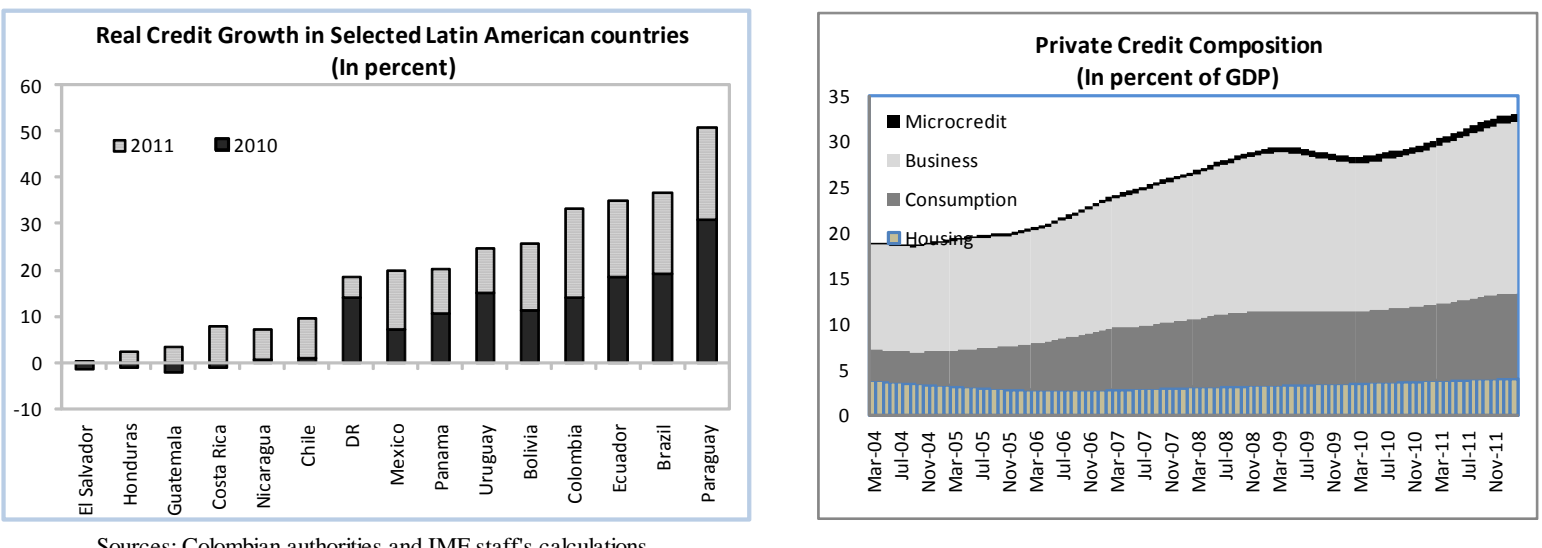

Sources: Colombian authorities and IMF staff's calculations.

\section{Domestic credit growth}

\section{An important potential source of domestic vulnerability could be the pace of}

expansion in bank credit. Supported by growth in output and employment, credit to the private sector has been growing at an average of 14 percent a year in real terms in recent years, among the highest in the region. This expansion has been characterized by more consumer credit, with non-mortgage consumer loans now accounting for almost 30 percent of total credit (up from 18 percent in 2004), and an increase in loan size, as opposed to a growing number of borrowers. Moreover, there is some vulnerability to interest rate risk, as half of all loans are contracted at a floating interest rate. ${ }^{6}$ The risks from rapid credit growth are mitigated by the strength of household and corporate balance sheets. Also risks derived from currency volatility are contained, as there are strict limits on currency and liquidity mismatches in foreign currency and over 90 percent of lending is in domestic currency.

\section{Asset bubbles}

13. There are few signs of asset bubbles in equity or housing prices, but the lack of depth and liquidity in key asset markets call for continued vigilance. The equity market could be prone to excessive price volatility, as it is illiquid with low trading volumes and a small free float. The state petroleum company (Ecopetrol) accounts for 40 percent of market capitalization, adding to the sensitivity to world oil prices, and its shares are liquid and account

\footnotetext{
${ }^{6}$ Almost 80 percent of business loans are contracted at floating rate, while most of consumption and microcredit loans are at fixed rates. Mortgages can be prepaid or restructured free of charge, which allows borrower to benefit from declines in the mortgage interest rate.
} 
for almost one-third of trading. Moreover, retail investors dominate holdings with over 1 million individual accounts, suggesting that equity price swings could have wealth effects on consumption. If sustained, the hike in housing prices could join with the reduction of the average debt-to-net wealth of households to 12 percent in 2011 (down from 19 percent in 2010) to fuel a consumption credit boom.

Figure 5. Colombia: Indices of Prices of Equities and Existing Houses

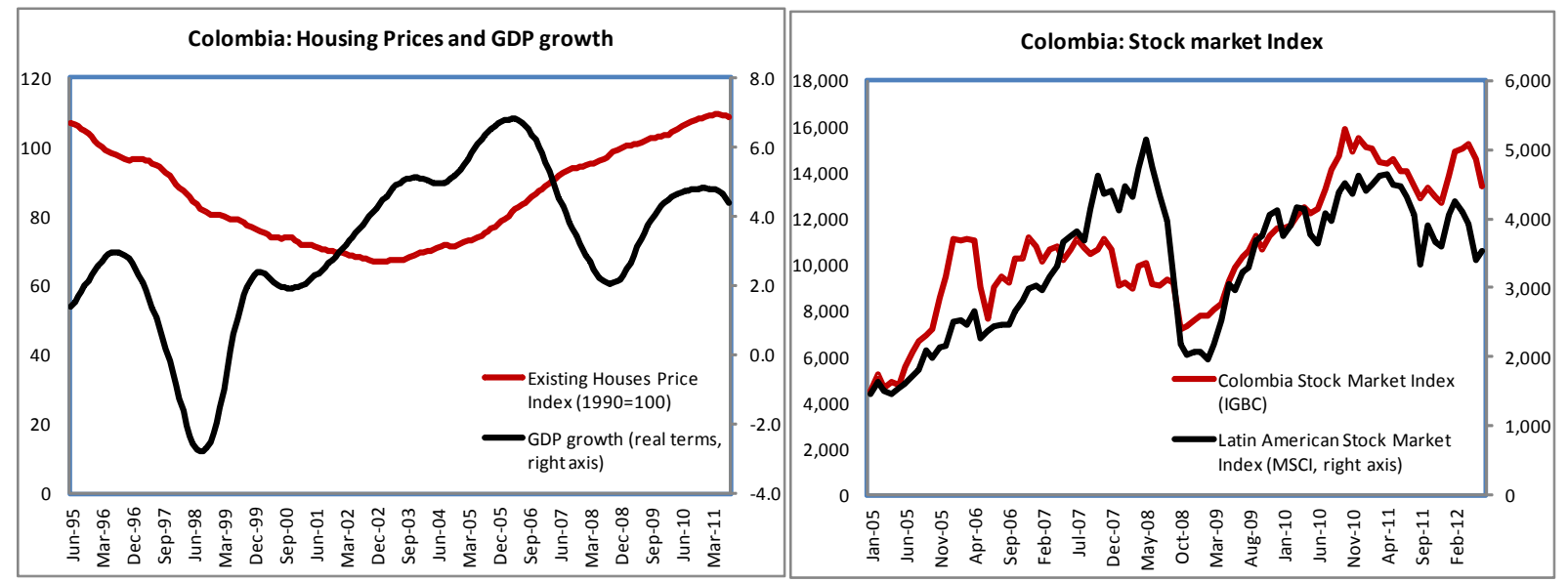

Sources: Colombian authorities and IMF staff's calculations.

\section{Stress tests}

\section{Due to high profitability, low credit risk and conservative business models,} Colombian banks appear resilient to a variety of shocks (Appendices II and III). Their substantial net interest income serves as solid cushion against the effects of losses related to credit risk, while their reliance on stable deposits for funding helps guard against liquidity shocks. The effect of market risk is contained by the low share of bank assets invested government and other fixed income assets. Banks maintain small exposures in the interbank market, keeping contagion risk quite low. However, more significant risks do arise from the high concentration of the commercial loan portfolio.

15. The stress tests were conducted with data as of March 2012 and with a measure of capital in line with international standards and broadly in line with the incoming regime.

All existing goodwill was subtracted, and all voluntary reserves were included, on the assumption that shareholders would agree to make this permanent before the new regime takes effect. Under this capital definition, regulatory capital at end-March 2012would amount to 13.7 of risk-weighted assets (Tier 1 CAR of 8.1 percent), and this estimate was the starting point for the CARs used in these tests. 
16. In the credit stress tests, the system-wide capital adequacy ratio remained well above the minimum. ${ }^{7}$ Under a macroeconomic crisis scenario that represented a 2.5 standard deviation shock to annual GDP growth - about twice the size of the post-Lehman shock, the system-wide CAR would fall by 2.3 percent points relative to the baseline to 12.9 percent after two years. Medium-sized banks (between 1 and 10 percent of system assets) would be the hardest hit, as their average CAR would fall to 10.9 percent. The CAR of three non-systemic banks would fall slightly below the regulatory minimum of 9 percent (the equivalent of 0.1 percent of total assets would be required to bring these banks' CAR above the minimum). The mission team simulated the effects of Colombia's system of dynamic provisioning, and found that this system provided a significant buffer to a number of banks to help absorb the costs of increased provisioning. A reverse stress test was also conducted and found that an immediate and permanent rise in NPLs of 300 percent would be required to bring the system-wide CAR to 9 percent after two years.

\section{The liquidity stress tests underline that the banking system as a whole is highly} liquid in the short term and sufficiently liquid in the medium and long term. These tests included the SFC's regulatory measure, the Liquidity Risk Index (LRI), as well as estimates of the Basel III Liquidity Coverage Ratio (LCR) and Net Stable Funding Ratio, which are not part of Colombia's regulatory framework. The average LCR for the system is almost 500 percent, although the ratios for two larger banks (accounting for 20 percent of system assets) are about 95 percent, slightly below the LCR benchmark of 100 percent. The NSFR averages about 140 percent, although some of the small banks (accounting for just 2 percent of system assets) show deficiencies in stable medium and long term funding.

18. The banking system is also resilient to market risk. A 300 basis point parallel shift in the yield curve leads to a slight decline in the system-wide from 13.7 percent to 13.4 percent, and no bank encounters a CAR below the minimum. It should be noted that this analysis also includes domestic sovereign bonds in the held-to-maturity portfolio, which are marked-to-market in the stress scenario instead of being priced at book value.

19. The most serious risk facing the banking system comes from its high exposure to the largest corporate borrowers. In a hypothetical, low probability scenario where the credit ratings of loans to the 100 largest private borrowers are downgraded by two grades under the loan classification system, the banking system's aggregate CAR would fall from 13.7 percent to 12.3 percent, while the Tier 1 ratio would fall from 8.1 percent to 6.7 percent. One non-systemic bank would fall below the regulatory minimum of 9 percent, while three non-systemic banks would have their Tier 1 capital fall below the new minimum of 4.5 percent. Against this background, these results point to the merit of tightening the limit on large exposures to help manage the system's exposure to concentration risk.

\footnotetext{
${ }^{7}$ The credit risk tests were conducted using a top-down approach. The SFC has not validated the internal credit risk models of the banks, making a bottom-up test unreliable.
} 
20. There appears to be a limited risk of contagion via direct interbank channels, given that banks hold relatively small claims on each other and other credit intermediaries. As of March 2012, banks' gross asset exposures to each other and other intermediaries represented only about 5 percent of total banking sector assets and were distributed in such a way that there are no substantial concentrations. Banks' high profits and large capital buffers mitigate losses incurred by nonpayment of other institutions. The limited effects of these interconnections were confirmed with a network analysis tool.

21. The stress test methodology of BR and SFC is sound, yet there is some room for improvement. The authorities have a well-functioning credit risk model in place that is linked to a structural macroeconomic model. The modeling of some elements of the income statement and of the evolution of risk-weighted assets could be enhanced along the lines of the FSAP stress test. Also, it would be useful to include scenarios that allow for access to the countercyclical capital buffer within the stress test, preferably by endogeneously assessing whether banks meet the access criteria. In light of the outcome of the concentration risk test, the authorities could also stress-test banks' exposures to very large borrowers. In liquidity stress testing, the LRI represents a broad adaptation of the LCR under Basel III customized to capture structural characteristics of Colombian banking such as different run-off rates and projected cash inflows. To safeguard prudent longer-term funding at smaller banks, the authorities should take their initial efforts further and adopt a version of the Basel III Net Stable Funding Ratio. The assessment of market risks is in line with international best practices.

\section{SUPERVISION OF THE FINANCIAL SYSTEM}

\section{A. Supervisory Architecture}

22. The SFC supervises all financial institutions and has a wide range of mandates. ${ }^{8}$ While this broad authority presents challenges for the organization and resources of the SFC, it does enable the SFC to promote the development of a common supervisory framework for the financial sector, facilitate access to information needed for the supervision of financial groups, which are often anchored by banks, and help contain regulatory arbitrage. This structure helped with the recent liquidation of a broker-dealer, because there were no questions with regard to the regulatory or legal authority for taking this action. The SFC has been working with the Toronto Center for the past few years to streamline its management structure and to promote an even stronger capacity for consolidated supervision and a comprehensive assessment of risks.

23. While the SFC is fully responsible for supervision, the ministry of finance (MHCP) takes the lead in issuing prudential regulations for the financial sector. The SFC plays a

\footnotetext{
${ }^{8}$ The only exception is non-deposit taking cooperatives, which are supervised by the Department of Economic Solidarity. These mandates include the preservation of the stability, safety and confidence of the financial system; organization and development of Colombian capital markets; protection of investors, depositors, insurance policy holders, and consumers of other financial services.
} 
critical role in the proposal, generation and comments of the decrees and regulations. It also has the full authority to issue instructions of mandatory compliance on a broad range of issues, including risk management, loan classification and provisioning, and accounting and reporting. The government recently created the Financial Regulation Unit (URF) to promote more fluid coordination between the SFC and the MHCP. This change was in response to concerns that the regulatory process at times was too slow and too prescriptive. There was no evidence of political interference, as the regulations followed technical considerations. This arrangement will continue to require excellent coordination between the two institutions to help ensure that SFC plays a key role in the regulatory process.

24. The SFC works with other institutions in many areas. On bank resolution, the SFC decides when to resolve a financial institution, but also works closely with the Guarantee Fund for Financial Institutions (FOGAFIN), which manages the deposit insurance system and administers intervened financial institutions. On anti-money laundering, the SFC works closely with the Unit for Financial Information and Analysis (UIAF) — a unit located in the ministry of finance that leads the country's AML/CFT efforts - to ensure that the financial system complies with international norms in this area. ${ }^{9}$ The SFC is a member of the Financial Stability Monitoring Committee (CCSSF), which includes the Banco de la Republica (BR), the MHCP as well as FOGAFIN.

\section{Since the SFC covers a broad regulatory perimeter, there are several critical supervisory issues that apply to all financial institutions:}

- $\quad$ Strengthening independence. The SFC has considerable de facto independence to undertake operations required by its mandates, and the supervisor carries out his functions with no political interference. However, there are issues with the jure independence of the SFC, as the President can dismiss the superintendent at any time without cause. Possible reforms to improve independence could include the requirement to appoint the superintendent for a fixed term or to require a public explanation of the reasons for dismissal.

- $\quad$ Strengthening legal protections. The SFC and its staff lack legal protection for acts carried out in good faith performance of their official duties. While some procedures help shield staff, there is still a potential chilling effect on appropriate action. The legal framework could clarify that liability for failure to perform the regulatory mandate in good faith should be defined as equivalent to acting in bad faith; and that the judicial authorities might limit those circumstances in which private parties would have standing to sue.

\footnotetext{
${ }^{9}$ The most recent AML/CFT assessment was completed in 2008 and the authorities have agreed to undertake an AML/CFT assessment in the first quarter of 2013.
} 
- $\quad$ Adopt a law extending its full regulatory and supervisory powers to holding companies of financial institutions. The SFC has no regulatory powers over financial holding companies, which can complicate its capacity for effective oversight. Such a law should provide a clear definition of financial group and give the SFC the powers to resolve a financial conglomerate as a whole. Now the SFC can resolve supervised members of conglomerate only on an individual basis.

- Adopt IFRS. The SFC recently published a timetable for the full adoption of IFRS by end-2015.

- $\quad$ Strengthen standards for external audits. While the SFC has the authority to oversee external auditors, it needs to adopt more rigorous standards for independence and publish the timetable to comply with international accounting and auditing standards.

\section{B. Banking Supervision}

26. The SFC exercises effective oversight of the banking system (Annex I). It enforces a robust framework for assessment of credit risk and asset classification and provisioning, and ensures that banks adopt prudent management of market, liquidity and operational risks. The authorization processes are well rounded and thorough, including licensing, transfers of ownership and investments. Of particular importance recently has been the process for the authorization of large acquisitions and investments, as Colombian banking groups have been expanding abroad through acquisitions of banks and banking groups, mainly in Central America. In this regard, the SFC has established an effective network of cooperation with other countries to exercise effective cross-border supervision of banking groups.

27. This new capital regime represents an important step forward from the outgoing capital adequacy rules. While the minimum capital adequacy ratio is 9 percent, the outgoing capital regime contains gaps, such as the inclusion of goodwill, all voluntary reserves and investments in unregulated subsidiaries. The $\mathrm{BCP}$ assessment evaluated the outgoing regime, because the new regime is not yet in effect, and concurred with the authorities' view on the need for significant improvements to bank capital.

\section{Colombia has a robust framework for AML/CFT and for addressing criminal} activities. ${ }^{10}$ While the UIAF takes the lead in monitoring compliance with this framework, the SFC's legal and regulatory framework provide guidance for the oversight for reporting

\footnotetext{
${ }^{10}$ The LEG report "Anti-Money Laundering and Combating the Financing of Terrorism: A Review of Recent Experience" (May, 2011) ranked Colombia the best among 115 emerging market countries in terms of compliance with the $40+9$ FATF principles. Colombia's performance was on par with the United Kingdom and the United States.
} 
suspicious activities for banks operating in Colombia. Nonetheless, there is some scope to improve its monitoring of the implementation of this framework by banks.

29. The SFC is in process of making supervision even more effective. While the SFC has a sound framework for the supervision of individual risks, it is still making progress in fully implementing comprehensive risk management. The SFC does have a general requirement that supervised entities manage their risks in a comprehensive way. However, this process would benefit from further formal written guidance with regards to the comprehensive risk management of banks and banking groups. Also there are no standards for the management of interest rate risk in the banking book and country and transfer risks, which matter in view of the significant share of loans with a floating interest rate and the expansion of Colombian banking groups abroad. In 2009 , the SFC began to implement a risk-based supervisory approach called the Integrated Supervisory Framework (MIS), with support from the Toronto Center. This framework has already strengthened the comprehensiveness of the SFC's assessments of each bank or conglomerate. Of course, the complete adoption of these reforms will take several more years, but once fully in place, these steps will ensure full implementation of a comprehensive riskbased approach.

\section{Large exposure and related party limits are in place but need to be more} comprehensive and streamlined. The rules for limiting large exposures could be simpler and allow fewer exceptions. More importantly, local affiliates are not consolidated and available unused credit lines are not taken into account in calculating neither large exposure limits nor related party lending. The definition of corporate control may create opportunities to bypass the related party limits.

\section{The consolidated supervision of financial conglomerates has been significantly} enhanced since the creation of the SFC. Improvements in the legal framework have empowered the SFC to conduct onsite exams and obtain necessary information from unsupervised members of financial conglomerates, to order the consolidation of financial statements of companies of these conglomerates, to exchange information with foreign supervisors and to authorize investments in the capital of foreign entities. Supervisory procedures are in place and a dedicated team is responsible for the supervision of financial conglomerates. The scope of the analysis covers the financial conglomerate, as well as the broader mixed conglomerate. However, the SFC would benefit from broader legal authority in this area, especially to oversee currently unregulated bank holding companies and to force changes in a group's structure.

\section{The SFC has established an effective network of cooperation for the purposes of} consolidated supervision of the financial conglomerates that operate in Colombia. There are no legal limitations for the supervisory cooperation. The SFC has signed MoU with most of the home and host supervisors of these conglomerates, which are published in the SFC web page. It engages in regular exchanges of information with these agencies. The SFC has organized the college of supervisors for Banco de Bogota with the participation of six foreign supervisory 
agencies, which had its first meeting in January 2012. The SFC has also become a member of the Central American Council of Banking Supervisors (CCSB), which is an effective forum for the coordination with the most of the host supervisors of the three largest Colombian groups.

33. Going forward, it is highly recommended to put in place a Basel II, Pillar 2 supervisory framework. This would give the SFC explicit authority to tailor prudential norms to the risk profile of each financial institution, especially the systemically important ones.

\section{Securities}

34. The regulatory and supervisory regime for securities is highly transparent and comprehensive and provides substantial authority to the SFC to oversee supervised entities Annex II). The Securities Law adopted in 2005, together with subsequent amendments, has enhanced customer protection and the ability to combat market abuse. In 2006 the AMV, a selfregulatory authority, became the front-line authority for oversight and sanctioning of market conduct. The SFC has made substantial efforts to bring Colombia into compliance with international standards, in particular meeting the standard for exchange of enforcement and surveillance information set by IOSCO by signing the MoU in May 2012. It has also worked actively within the Colombian system to meet the new expectations contained in the IOSCO principles adopted in June 2010, relating among other things to systemic risk and hedge funds. In this regard, the SFC has extraordinary administrative powers in the securities sector that exceed those of many jurisdictions, including the ability to freeze and seize assets, including assets of non-supervised entities and parties, and to intervene in the event of market disruption and defaults.

\section{Despite this significant progress, further improvements can be made in several} areas. In particular, the SFC could tighten oversight of operators of collective investment vehicles, including broker-dealers, to strengthen investor protection and improve the management of uncollateralized risks. Another key area is to develop a better system for protection of minority shareholder rights - especially important given the complexity of Colombian corporations.

\section{Insurance}

36. During the last five years, a number of important regulatory reforms have been introduced to improve the regulation and supervision of the insurance industry (Annex III). The solvency position of the industry has been strengthened through more riskbased and improved capital and solvency provisions, though not yet Solvency II. Requirements for risk management and internal control systems have been established and those for investments improved. Public disclosure of financial information is strong. New mortality tables for use in life insurance have been developed and introduced. Revised insolvency and liquidation procedures are being developed, and a stronger consumer protection regime has been crafted for financial services markets. Increasing consumer confidence and continued progress towards international regulatory standards depends on further progress in oversight. 
37. Despite this progress, there are several areas for continued improvement. The SFC is working on further enhancements to align solvency requirements with international standards, especially with regards to reserving practices and capital requirements. Actuarial capacity in Colombia is low (perhaps less than 120 professionals), and fuller actuarial programs at local universities may be a start towards addressing this problem. In addition, a plan should be developed towards establishing a self-regulating actuarial profession charged with establishment of actuarial standards, accreditation and disciplining its members. Policyholders with outstanding claims need to be given clear legal priority in the event of liquidation.

\section{Financial Safety Net}

\section{A. Systemic Liquidity Provision}

38. Overall, liquidity flows through the Colombian financial system smoothly. Typically, the interbank interest rate trades virtually in line with the policy interest rate. The BR plays a central role in the liquidity system, adjusting liquidity under ordinary circumstances to the financial system through several channels, including open market repurchase operations against government securities with all financial institutions and intra-day repurchase operations (also against government securities) to participants in the payments system. The BR is wisely planning to extend access to intra-day repos to market infrastructure institutions, such as clearing houses, which are becoming systemic. ${ }^{11}$ The flip side of the BR's prominent role is that the interbank money market is very limited.

39. The recent intervention of a broker-dealer points to the potential for liquidity and other risks to disrupt the payment system. Broker-dealers can be highly vulnerable, as they can take large net intraday exposures that vastly exceed their capital and liquidity buffers. These institutions are closely interconnected through payment relationships with other financial companies: two broker-dealers are among the ten financial institutions with the most interconnections in the payments system. In response, the BR is prepared to provide intra-day liquidity to broker-dealers to contain the possible contagion from a liquidity squeeze in a broker-dealer. In general, this liquidity is limited by the institution's holdings of eligible collateral-government securities - although in the aftermath of the recent intervention the BR has been providing liquidity to other broker-dealers against corporate securities for a temporary period. Going forward, it would be advisable to tighten liquidity requirements for broker-dealers and other NBFIs and to undertake more rigorous stress testing of these institutions.

40. Although the BR's routine liquidity operations function smoothly, there may be scope to strengthen the role of the interbank money market. Options include narrowing the

\footnotetext{
11 The derivatives clearing house CRCC has prospered since 2008 without access to intra-day central bank credit, but it is growing very fast and becoming more systemically important. The BR's plan will enable CRCC not only to receive intra-day repos, but also to convert intra-day repos into overnight repos (and longer) in case of need.
} 
range of counterparties for open market operations to banks and primary dealers in government securities, because of the liquidity risks they necessarily run and raising the cost of excessive use of overnight credit. Other remedial actions include phasing out the financial transactions tax more quickly than already planned and expanding the issuance of short-term government securities.

41. The BR's lender of last resort facility could be strengthened. Now, the law requires it to lend only to credit institutions, although against a wider range of collateral than government securities. The BR may need to lend to broker-dealers, trust companies and clearing houses in a crisis when traditional channels of liquidity may break down. The intra-day repo facility, and the facility to convert intra-day repos to overnight repos, gives the BR the ability to lend to such companies if they have eligible collateral. The wider the range of eligible collateral, the better able the BR will be to assist in crisis management. In addition the foreign currency clearing house in Colombia could experience liquidity problems if one or more members failed to complete transactions, and in an emergency its liquidity providers might need temporary dollar liquidity support. As a back-up, it would be desirable for the BR to be ready to swap dollars from the foreign exchange reserves for pesos with liquidity-providing banks in case of need.

\section{B. Deposit Insurance}

42. FOGAFIN manages a sound system of deposit insurance. The current coverage limit is about US $\$ 11,000$ (about 150 percent of per capita income) per depositor per institution. The system covers all deposit-taking financial institutions, who must participate in the system, and covers 98 percent of the depositors in full, but only 20 per cent of the total value of deposits, with no coinsurance. Deposit insurance is funded by annual premiums collected from member institutions and investment income. Besides managing the deposit insurance system, it provides open bank assistance, and conducts modified purchase and assumption transactions with the exclusion of assets and liabilities. As is the case with the SFC, FOGAFIN's board and staff have no legal protection for actions carried out in good faith execution of their official responsibilities.

\section{FOGAFIN relies on the SFC to assess the financial soundness of credit} establishments, underscoring the importance of information sharing. Recently the SFC

agreed to inform FOGAGIN when a financial institution is at significant risk of being intervened. With the support of the SFC, banks have been required to begin to report detailed information on their deposits directly to FOGAFIN starting in 2014.

\section{Bank Resolution}

44. The SFC has a broad range of preventive and corrective powers that have been used effectively. These measures include moral suasion and issuance of administrative orders, cease and desist orders and sanctions. Specific steps can include establishing an enhanced surveillance, under which the institution must follow the SFC requirements for its operation; coordinating actions with the deposit insurance; fostering the fiduciary administration of the assets and business by another authorized institution; ordering the recapitalization of the institution; 
fostering the partial or total transfer of the assets, liabilities or contracts or the sale of its commercial establishments to another institution; ordering the merger of the institution; and ordering the adoption of a recovery plan.

\section{The legal options for bank resolution are comprehensive and broad, yet could be} improved in two areas.

- $\quad$ Excessively long period of possession. Once a financial institution has been intervened, FOGAFIN has a period of two months (which can be extended) to decide on the best resolution option. Such a long administration period adds to the risks of shareholder lawsuits and a further loss of confidence in the institution, and it would be advisable to shorten this period.

- $\quad$ Too much flexibility in the choice of options. Currently the authorities can choose among a wide range of resolution options, and this latitude opens the door to pressure to select an option that unduly favored shareholders or certain creditors. The authorities are preparing a protocol to organize the resolution options using a decision tree that would separate systemic from non-systemic cases and identify the resolution options applicable in each case. It would be important that the protocol incorporate essential resolution principles (selection of the least cost option, minimize contagion risks, first losses to shareholders, transparency and fairness, prefer private solutions and quick response) and be public. Moreover, while introducing a legal reform is always complex, there are clear advantages to embedding this protocol in the legal framework to limit risks to the resolution process.

\section{FinANCIAL STABILITY AND MACROPRUdENTIAL FraMEWORK}

\section{A. Institutional Arrangements}

46. The CCSSF - formed in the aftermath of the 1999 financial crisis - seeks to ensure close coordination among the SFC, BR, MHCP and FOGAFIN, especially during a crisis. It allows for discussion of proposed regulations and macroprudential policies. While respecting the autonomy and mandates of each institution, the CCSSF has fostered an exchange of information and stimulated the discussion about certain policy actions in support of financial stability, particularly in recent years.

\section{However, the CCSSF's effectiveness as a coordination body would benefit from a} greater degree of formality. It would be important to introduce a strategic action plan for dealing with systemic risk that respects the legal mandates of each institution. The CCSSF should develop a long-term work plan to investigate key issues, such as an agreed methodology to identify and monitor systemic risk and establish the perimeter for measuring systemic risk. In the case of systemic crises, the CCSSF should be the entity coordinating systemic measures, including action plans and a clear process for decision making. This action plan should be 
comprehensive enough to deal with and possibly resolve SIFIs, financial conglomerates and large non-bank financial institutions.

\section{B. Macroprudential Tools and Policies}

\section{The authorities have relied on a broad range of policy instruments to address} macroprudential risks. Structural measures, such as the legal limits on loan to value and debt service to income, have been in effect since the 1999 crisis. Steps to contain systemic risks have included marginal reserve requirements, changes in provisioning and collateral requirements for consumer credit, limits on the exposure of financial institutions in derivative operations, limits on net open foreign exchange positions of financial institutions and a requirement to match the maturity structure of net foreign exchange positions. An unremunerated reserve requirement on capital inflows was used most recently as 2007. Going forward, there would be benefits to extending provisioning requirements on consumer credit on the unused portion of credit lines and tailoring provisioning rates to the debt service ratio of the borrower. ${ }^{12}$

49. The system for countercyclical loan loss provisioning has been beneficial, although it is more of a tool to mitigate microprudential risk. This scheme allows each credit institution to create an additional buffer of loan loss reserves in good times in order to cushion a rise in specific provisioning costs during a subsequent downturn. This system is capable of creating a broadly adequate buffer for a downturn, but staff simulations show that the countercyclical buffer may not be depleted fully during a moderately severe downturn episode, owing in part to an asymmetry between the rules for accumulation and drawing down. Going forward, the authorities might want to consider phasing in countercyclical capital buffers to address systemic shocks, but it would be crucial to understand how such a system would dovetail with the countercyclical loan loss provisioning.

\footnotetext{
${ }^{12}$ Much of the growth in consumer credit has been an expansion in authorized credit lines. Credit conversion factors are commonly used to address the probability of an unused credit line becomes outstanding credit one year ahead.
} 
Table 2. Colombia: Financial System Structure

\begin{tabular}{|c|c|c|c|c|}
\hline Type of Entity & Number & $\begin{array}{l}\text { Total Assets } \\
\text { end-2011 } \\
(\text { COP mn })^{1}\end{array}$ & $\begin{array}{l}\text { Percent of } \\
\text { Total } \\
\text { Assets }^{1} \\
\end{array}$ & $\begin{array}{c}\text { Percent of } \\
\text { end-2011 } \\
\text { GDP }^{1} \\
\end{array}$ \\
\hline Banks & 23 & $295,954,567$ & 54.5 & 48.8 \\
\hline Domestic private & 13 & $222,249,352$ & 40.9 & 36.6 \\
\hline Domestic public & 1 & $16,336,151$ & 3.0 & 2.7 \\
\hline Foreign private & 9 & $57,369,064$ & 10.6 & 9.5 \\
\hline Financial corporations & 4 & $8,418,513$ & 1.6 & 1.4 \\
\hline Financing companies & 22 & $18,918,567$ & 3.5 & 3.1 \\
\hline Fiduciaries & 27 & $1,834,150$ & 0.3 & 0.3 \\
\hline Collective investment funds & $\ldots$ & $28,364,982$ & 5.2 & 4.7 \\
\hline General insurance companies & 23 & $11,253,641$ & 2.1 & 1.9 \\
\hline Premiums $^{2}$ & $\ldots$ & $7,667,529$ & 1.4 & 1.3 \\
\hline Life insurance companies & 19 & $22,352,096$ & 4.1 & 3.7 \\
\hline Premiums ${ }^{2}$ & $\ldots$ & $5,914,025$ & 1.1 & 1.0 \\
\hline Insurance cooperatives & 2 & 476,971 & 0.1 & 0.1 \\
\hline Special official institutions & 11 & $37,527,374$ & 6.9 & 6.2 \\
\hline $\begin{array}{l}\text { Pension fund administrators } \\
\text { Value of obligatory pension }\end{array}$ & 6 & $2,701,793$ & 0.5 & 0.4 \\
\hline $\begin{array}{l}\text { funds } \\
\text { Value of voluntary pension }\end{array}$ & $\ldots$ & $91,473,158$ & 16.8 & 15.1 \\
\hline funds & $\ldots$ & $11,546,596$ & 2.1 & 1.9 \\
\hline Value of severance funds & $\ldots$ & $5,673,745$ & 1.0 & 0.9 \\
\hline Financial cooperatives & 6 & $1,991,584$ & 0.4 & 0.3 \\
\hline Brokerage firms & 28 & $4,422,378$ & 0.8 & 0.7 \\
\hline Total & 171 & $542,910,114$ & 100.0 & 89.5 \\
\hline
\end{tabular}




\section{Table 3. Colombia: Selected Economic and Financial Indicators}

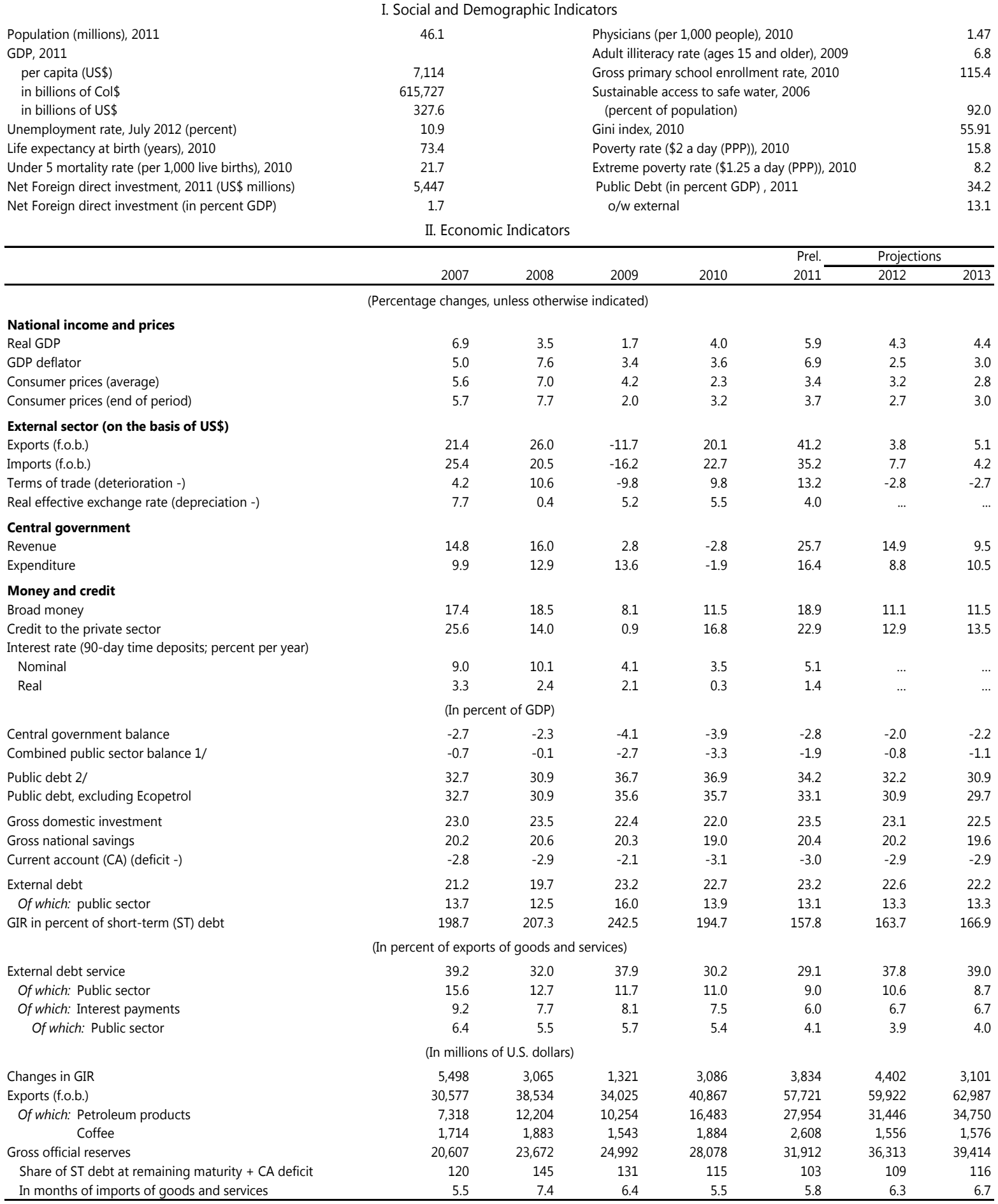

Sources: Colombian authorities; UNDP Human Development Report; World Development Indicators; and Fund staff estimates and projections.

1/ Includes the quasi-fiscal balance of Banco de la República, Fogafin balance, net cost of financial system restructuring, and statistical discrepancy.

2/ Includes Ecopetrol and Banco de la República's outstanding external debt. 
APPENDIX I. COLOMBIA: RISK ASSESSMENT MATRIX

\begin{tabular}{|c|c|c|}
\hline \multirow{2}{*}{$\begin{array}{l}\text { Nature/Source of Main } \\
\text { Threats }\end{array}$} & \multicolumn{2}{|c|}{ Overall Level of Concern } \\
\hline & $\begin{array}{l}\text { Likelihood of Severe Realization } \\
\text { in the Next } 1-3 \text { Years }\end{array}$ & $\begin{array}{l}\text { Expected Impact on Financial } \\
\text { Stability if Realized }\end{array}$ \\
\hline $\begin{array}{l}\text { Sudden stop in capital } \\
\text { inflows }\end{array}$ & $\begin{array}{l}\text { Staff assessment: medium } \\
\text { - With the continued uncertainty } \\
\text { in the global economy, the VIX } \\
\text { could reach crisis levels. As risk } \\
\text { aversion increases, net capital } \\
\text { inflows could experience a } \\
\text { sudden stop. }\end{array}$ & $\begin{array}{l}\text { Staff assessment: medium } \\
\text { - Domestic asset prices would } \\
\text { decline. } \\
\text { - Banks' portfolios will be } \\
\text { exposed to higher market risk } \\
\text { due to increased capital } \\
\text { market volatility. } \\
\text { - Slowdown in real GDP growth } \\
\text { could raise NPLs. }\end{array}$ \\
\hline $\begin{array}{l}\text { Sharp rise in U.S. interest } \\
\text { rates }\end{array}$ & $\begin{array}{l}\text { Staff assessment: low } \\
\text { - The level of interest rates in the } \\
\text { U.S. is unusually low, and the } \\
\text { yield curve is extremely flat, and } \\
\text { this situation could change. } \\
\text { Consequently, Colombia would } \\
\text { experience sharp interest rate } \\
\text { increases. } \\
\text { - However, U.S. may continue to } \\
\text { benefit from its status as a safe } \\
\text { haven and the Fed has } \\
\text { indicated that U.S. monetary } \\
\text { conditions would remain highly } \\
\text { accomodative. }\end{array}$ & $\begin{array}{l}\text { Staff assessment: medium } \\
\text { - Effects of the } 2008 \text { GFC were } \\
\text { dampened by low interest } \\
\text { rates in the US. However, with } \\
\text { an increase in U.S. rates, } \\
\text { banks will face higher } \\
\text { borrowing costs; portfolio } \\
\text { quality will decline as } \\
\text { consumers face higher interest } \\
\text { rates and real GDP growth } \\
\text { slows. The authorities will } \\
\text { have less room for policy } \\
\text { maneuver. }\end{array}$ \\
\hline $\begin{array}{l}\text { Terms of trade } \\
\text { shock/reduction in net } \\
\text { exports }\end{array}$ & $\begin{array}{l}\text { Staff assessment: low } \\
\text { - A global recession affecting } \\
\text { major economies and important } \\
\text { trading partners, leading to a } \\
\text { drop in commodity prices, could } \\
\text { result in a terms of trade } \\
\text { shock/lower demand for exports } \\
\text { and reduce overall GDP growth. }\end{array}$ & $\begin{array}{l}\text { Staff assessment: medium } \\
\text { - Reduced revenue and demand } \\
\text { in the energy sector could } \\
\text { result in a deterioration of } \\
\text { lending portfolios to this sector. } \\
\text { However, much of this sector } \\
\text { is financed through FDI. } \\
\text { - General economic slowdown } \\
\text { could result in a deterioration } \\
\text { of overall lending portfolios } \\
\text { and lower revenues. }\end{array}$ \\
\hline
\end{tabular}




\begin{tabular}{|c|c|c|}
\hline \multirow{2}{*}{$\begin{array}{l}\text { Nature/Source of Main } \\
\text { Threats }\end{array}$} & \multicolumn{2}{|c|}{ Overall Level of Concern } \\
\hline & $\begin{array}{l}\text { Likelihood of Severe Realization } \\
\text { in the Next } 1-3 \text { Years }\end{array}$ & $\begin{array}{c}\text { Expected Impact on Financial } \\
\text { Stability if Realized }\end{array}$ \\
\hline Distress in large borrower & $\begin{array}{l}\text { Staff assessment: low } \\
\text { - With } 90 \text { percent of commercial } \\
\text { lending concentrated in } \\
7 \text { percent of borrowers, distress } \\
\text { of a large borrower could take } \\
\text { place and weaken overall credit } \\
\text { quality. However, extremely low } \\
\text { probably of many large } \\
\text { borrowers experiencing } \\
\text { difficultities at the same time. }\end{array}$ & $\begin{array}{l}\text { Staff assessment: high } \\
\text { - Banks could experience } \\
\text { reduction in profits/increased } \\
\text { NPLs/liquidity shortages } \\
\text { depending on the severity of } \\
\text { borrower distress. }\end{array}$ \\
\hline $\begin{array}{l}\text { Deterioration of consumer } \\
\text { lending portfolio }\end{array}$ & $\begin{array}{l}\text { Staff assessment: low } \\
\text { - Recent rapid expansion in } \\
\text { consumer lending could result } \\
\text { in lower quality portfolios as } \\
\text { lending standards are relaxed. } \\
\text { A global/domestic downturn } \\
\text { could affect borrowers' ability to } \\
\text { make payments. }\end{array}$ & $\begin{array}{l}\text { Staff assessment: medium } \\
\text { - Increased NPLs. } \\
\text { - Banks will reverse the recent } \\
\text { increase in lending as they } \\
\text { deleverage, further deflating } \\
\text { domestic economic activity. }\end{array}$ \\
\hline Housing price collapse & $\begin{array}{l}\text { Staff assessment: low } \\
\text { - With housing prices growing } \\
\text { steadily for upper-income } \\
\text { homes for several years, they } \\
\text { are now at historic highs (in real } \\
\text { terms). While the potential risk } \\
\text { is partially mitigated by average } \\
\text { LTV ratios of around } \\
50 \text { percent, mortgages have the } \\
\text { highest NPL ratio across } \\
\text { lending portfolios (8.3 percent) } \\
\text { and a collapse in the housing } \\
\text { market would push this higher. }\end{array}$ & $\begin{array}{l}\text { Staff assessment: medium } \\
\text { - NPLs in this sector and related } \\
\text { sectors will increase. Although } \\
\text { LTV ratios are low and } \\
\text { mortgage lending represents } \\
\text { only } 8 \text { percent of total lending, } \\
\text { after the banking crisis of the } \\
\text { late } 1990 \text { s, NPLs in this } \\
\text { segment reached } 40 \text { percent. }\end{array}$ \\
\hline
\end{tabular}




\section{APPENDIX II. COLOMbIA: STRESS TEST MATRIX FOR SOlVENCY RISK}

\begin{tabular}{|c|c|c|}
\hline \multirow[t]{2}{*}{ Domain } & \multicolumn{2}{|r|}{ Assumptions } \\
\hline & $\begin{array}{r}\text { BU } \\
\text { Autho }\end{array}$ & Top-down by FSAP Team \\
\hline Institutions included & $\mathrm{N} / \mathrm{A}$ & -23 banks \\
\hline Data & & -Supervisory and market data \\
\hline Forecasting Horizon & & -2 years (8 quarters) \\
\hline Scenarios & & $\begin{array}{l}\text { - Baseline scenario according to BR forecasts, cross-checked } \\
\text { with other institutions' projections } \\
\text { - Terms of Trade Shock: decrease in the terms of trade } \\
\text { induced by a reduction of Colombia's exports plus } 2.5 \\
\text { percentage points growth shock to Colombia's most } \\
\text { important regional trading partners in Latin America } \\
\text { (Brazil, Chile, Ecuador, and Venezuela) } \\
\text { - Macroeconomic Crisis scenario: ( } 2.5 \text { standard deviations in } \\
\text { GDP growth from trend growth during two years), internal } \\
\text { and external shocks. }\end{array}$ \\
\hline Methodology & & $\begin{array}{l}\text {-TD balance sheet solvency stress test } \\
\text { - Components: modeling of exposure evolution, net profits } \\
\text { and capital evolution, stressed funding costs, taxation, } \\
\text { countercyclical buffer, rating harmonization, Quasi-IRB } \\
\text { estimation of RWA. } \\
\text { - Two methodologies: (1) constant balance sheet based } \\
\text { solvency stress test (along the lines of EBA and SCAP), (2) } \\
\text { credit risk combined with credit growth, along with } \\
\text { assumptions for backing growth in loan portfolio with } \\
\text { capital. }\end{array}$ \\
\hline Risks/factors assessed & & $\begin{array}{l}\bullet \text { Solvency risk } \\
\bullet \text { Credit concentration risk } \\
\bullet \text { Funding risk } \\
\text { - Access to countercyclical buffer }\end{array}$ \\
\hline Regulatory standards & & $\begin{array}{l}\text { - According to Colombia's banking sector regulation: Basel } \\
\text { I-type of framework. } \\
\text { - Capital definition: adapted to better reflect international } \\
\text { standards (e.g., exclusion of goodwill); total capital (CAR) } \\
\text { - Regulatory minimum (CAR): total capital (own funds) } 9 \\
\text { percent of RWA. }\end{array}$ \\
\hline $\begin{array}{l}\text { Calibration of risk } \\
\text { parameters }\end{array}$ & & $\begin{array}{l}\text { - Macroeconomic scenarios: Model based (DSGE, VECM), } \\
\text { both BR. } \\
\text { •Credit risk parameters: credit risk regression model } \\
\text { (changes in nonperforming loans); credit growth; }\end{array}$ \\
\hline
\end{tabular}




\begin{tabular}{|c|c|c|c|c|c|c|c|}
\hline \multirow[t]{3}{*}{ Domain } & \multicolumn{7}{|c|}{ Assumptions } \\
\hline & $\begin{array}{c}\text { BU by } \\
\text { Authorities }\end{array}$ & & \multicolumn{5}{|c|}{ Top-down by FSAP Team } \\
\hline & & \multicolumn{6}{|c|}{$\begin{array}{l}\text { regression model (size of loan portfolio) } \\
\text { - Loan loss provision ratios according to historical } \\
\text { realizations (stressed vs. nonstressed periods) } \\
\text { - Average tax rate on operating profits; nonincome taxation } \\
\text { - Concentration risk shocks (harmonization of loan } \\
\text { classifications; downgrade of harmonized classifications by } \\
\text { and two letter grades; calculation of stress-induced } \\
\text { provisions) }\end{array}$} \\
\hline Result Presentation & & \multicolumn{6}{|c|}{$\begin{array}{l}\text {-CAR, system-wide; and for individual banks by means of } \\
\text { distributions } \\
\text { - Number of banks below capital threshold, their share of } \\
\text { system's total assets, and recapitalization needs } \\
\text {-Evolution of NPLs } \\
\text {-Sensitivity tests for credit concentration risk }\end{array}$} \\
\hline \multirow[t]{4}{*}{ Output } & & Constant Balance Sheet & $\begin{array}{l}\text { CAR } \\
\text { (t8) }\end{array}$ & $\begin{array}{c}\text { NPL } \\
\text { Ratio (t8) }\end{array}$ & $\begin{array}{c}\text { No. Banks } \\
<9 \%\end{array}$ & $\begin{array}{c}\% \text { of } \\
\text { system's } \\
\text { TA }<9 \% \\
\end{array}$ & $\begin{array}{c}\text { Recap in \% } \\
\text { of Annual } \\
\text { GDP }\end{array}$ \\
\hline & & Baseline & $15.2 \%$ & $4.2 \%$ & 1 & $0.7 \%$ & $0.002 \%$ \\
\hline & & Terms of Trade Shock & $15.0 \%$ & $4.4 \%$ & 1 & $0.7 \%$ & $0.004 \%$ \\
\hline & & Macroeconomic Crisis & $12.9 \%$ & $5.0 \%$ & 3 & $15.0 \%$ & $0.100 \%$ \\
\hline
\end{tabular}


APPENDIX III. COLOMBIA: STRESS TEST MATRIX FOR LIQUIDITY RISK

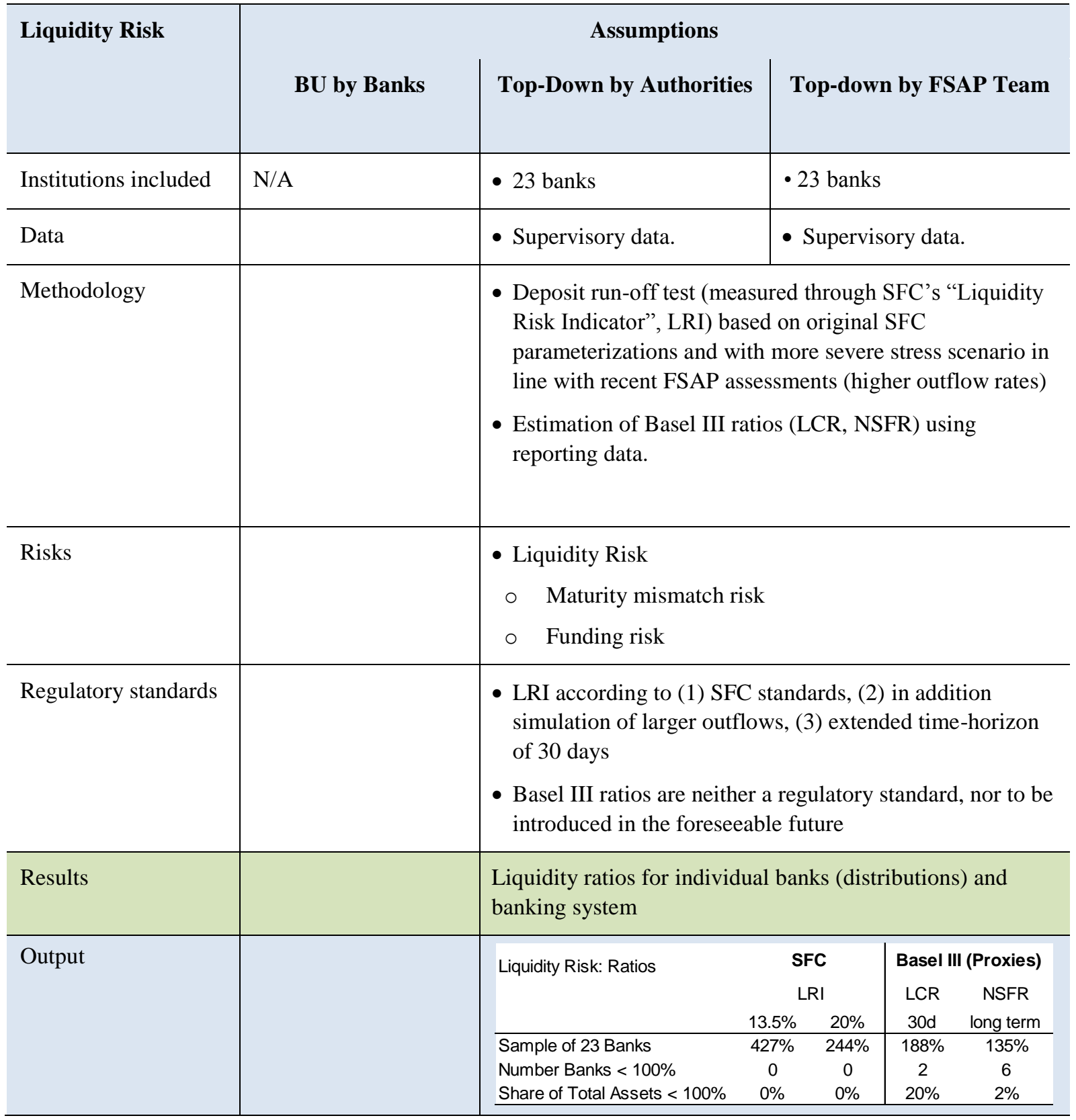




\section{Annex I. Basel Core Principles-Summary Assessment}

50. This assessment of the state of compliance with the BCPs in Colombia has been undertaken as part of an IMF / World Bank Observance of Standards and Codes (ROSC) mission. ${ }^{13}$ The assessment was conducted from May 28 to June 12, 2012. It reflects the banking supervision practices of the Financial Superintendency of Colombia as of May 2012.

\section{INFORMATION AND METHODOLOGY USED FOR ASSESSMENT}

51. The assessment is based on the following sources: (i) a complete self-assessment prepared by the SFC; (ii) answers provided by the SFC to a pre-mission questionnaire; (iii) presentations and detailed interviews with the SFC staff; (iv) review of laws, regulations, and other documentation on the supervisory framework and practice, and on the structure and development of the Colombian banking sector; and (v) meetings with individual banks, the banking association, the Ministry of Finance (MoF) and external auditors.

52. The assessment was performed in accordance with the guidelines set out in the Core Principles (CPs) Methodology. ${ }^{14}$ It assessed compliance with the "essential" criteria (EC) only, albeit the detailed assessment includes a description of the compliance with additional criteria (AC). The Methodology requires that the assessment be based on the legal and other documentary evidence, combined with a review of the work of the supervisory authority as well as its implementation in the banking sector. The assessment of compliance with the CPs is not, and is not intended to be, an exact science. Banking systems differ from one country to the next, as do their domestic circumstances. Furthermore, banking activities are changing rapidly around the world, and theories, policies, and best practices of supervision are swiftly evolving. Nevertheless, it is internationally acknowledged that the CPs set minimum standards.

53. This assessment is based solely on the laws, supervisory requirements, and practices that were in place at the time it was conducted. However, where applicable the assessors made note of regulatory and supervisory initiatives which have yet to be completed or implemented. In particular, regulations on capital, the planned reform of the SFC structure and the ongoing implementation of the Marco Integral de Supervision (MIS), a risk based supervisory framework.

54. The assessment team enjoyed excellent cooperation with its counterparts and, within the time available to perform their work, reviewed all the information provided. The team extends its thanks to the management and staff of the SFC for their openness and participation in the process.

\footnotetext{
${ }^{13}$ The mission was led by Mr. Robert Rennhack (IMF) and Eva Gutierrez (World Bank). The assessment was conducted by Ms. Valeria Salomao Garcia (World Bank) and Ms. Socorro Heysen (expert consultant).

${ }^{14}$ Issued by the Basel Committee on Banking Supervision, October 2006.
} 


\section{Main Findings, SUmmary ANd RECOMMENdATIONS}

\section{A. Main Findings}

55. Since the last FSAP update in 2004, Colombia has strengthened bank regulation and supervision in various respects. The merger of the securities supervisor with the banking and insurance supervisor to establish the SFC as an integrated supervisor has been an important step towards the development of a common supervisory framework for the financial entities and has facilitated access to information needed for the supervision of banking groups. A framework for the regulation and supervision of most risks (SAR) has been implemented and specialized risk units (including AML) are responsible for risk supervision of banks, insurance and securities companies. In addition, a specialized unit is responsible for the supervision of financial conglomerates and corporate governance. There are, however, shortcomings that would need to be addressed with regards to: the independence of the SFC, legal protection of supervisors, the capital adequacy framework, risk management, the supervisory approach, external audit and consolidated supervision.

\section{Objectives, independence, powers, transparency, and cooperation (CP1)}

56. The SFC has operational autonomy within a general framework established by the government, but the lack of procedures for the appointment and dismissal of the superintendent may limit his independence. The SFC has the ability to define its supervisory plans and methodologies, make major supervisory decisions and impose sanctions on supervised entities without prior authorization of other authorities. It also defines its budget, within the limits of the general public sector policies. However, there are no procedures for the appointment and dismissal of the Financial Superintendent, who can be removed by the President without disclosure of the reasons, a limitation that may make him vulnerable to political pressure.

\section{The allocation of the regulatory powers on the Presidency demands a proper} framework and a great deal of coordination to ensure its effectiveness. The main prudential regulations (capital, exposure limits, operations of financial institutions and corrective action and resolution framework) and the regulations on the organization of the SFC are issued through Presidential decrees processed by the MoF. The SFC can issue instructions of mandatory compliance on a broad range of issues including: risk management, loan classification and provisioning, accounting and reporting. This arrangement requires excellent coordination between the MoF and the SFC and a proper framework to ensure that the regulations are well grounded on international best practice, free of political interference and updated as frequently as necessary.

58. The recent creation of the URF seeks to enhance the autonomy of the regulatory process and the opportunity of its response to regulatory needs. This is an important step toward the establishment of a proper framework for the development of prudential regulation. However, this framework could be further improved to strengthen its independence and 
effectiveness. It is recommended that: (i) the selection process of all the board members of the URF, not only the independent ones, ensure that they are technically fit and free of conflict of interest; (ii) all Board members are appointed for a fixed term in office and the reasons for their removal should be clearly stipulated in the decree; (iii) a formal understanding is developed to ensure an adequate balance between the regulations issued by the MoF, which should be generally principled based, and those issued by the SFC, which should cover areas that are more likely to require more frequent revision and deep knowledge of supervisory practice; and (iv) some language is introduced in the URF decree to ensure that the SFC has a key role in the regulatory process, so that regulations can be effectively supervised.

59. The law does not provide legal protection to the Superintendent and staff of the SFC against lawsuits for actions taken and/or omissions made while discharging their duties in good faith. It is recommended that the law be amended to provide this protection. For instance, the law could require that, prior to suing supervisors in criminal or civil courts for actions or omissions during the course of duty, a judgment must be obtained against the SFC.

\section{Licensing and structure (CPs 2-5)}

60. The powers with regards to the declaration of illegal deposit taking and the intervention of establishments engaging in such activities were strengthened after the 2008 pyramid crisis. The 2008 events showed that these establishments had adopted schemes to circumvent the regulation and prevent the intervention of the authorities. Decree 4334 of 2008 allows the intervention of these establishments when, in the opinion of the Superintendency of Corporations or the SFC, there are objective or notorious facts that indicate the massive taking of money, directly or indirectly, through a broad variety of schemes. The SFC has a large dedicated group in charge of investigating and pursuing illegal deposit taking activities banking (25 people). In 2010, this group investigated more than 600 cases of suspected illegal deposit taking, conducted inspection to more than 100 and concluded that 18 of them were conducting illegal activities, of which most of them took action to adjust to the legal limits and 6 of them were intervened and prosecuted). The SFC also informs the public about entities that are posing as supervised entities or deposit taking entities.

61. The SFC authorization processes are well rounded and robust, including licensing, transfers of ownership and investments. Of particular importance recently has been the process for the authorization of large acquisitions and investments. In the past few years, Colombian banking groups have expanded abroad through acquisitions of banks and banking groups, mainly in Central America. The significance of ensuring proper identification of the risks of these acquisitions and adequate ongoing control of these investments by the acquiring banks, has been taken very seriously by the SFC. In this regard, the SFC has significantly strengthened the process for authorization of acquisitions abroad. 


\section{Prudential regulation and requirements (CPs 6-18)}

62. The capital adequacy rules would benefit from further enhancement. Colombia has not formally adhered to any of the Basel capital standards, albeit the regulation follows many of the Basel I rules. The capital adequacy ratio is higher than the minimum Basel standard but there are some gaps in its scope of application and in the range of risks covered; and some of its components do not have the appropriate loss absorption capacity. Banks are required to maintain a capital adequacy ratio of 9 percent of risk weighted assets for credit and market risks, on a solo and consolidated basis. However, capital for market risk does not cover foreign subsidiaries and the SFC cannot require capital for other risks. The definition of capital includes voluntary reserves and does not deduct goodwill and investments in unregulated subsidiaries. Finally, the risk weight applied for exposures with sovereigns is low and independent of risk (zero the local government and 20 percent for foreign governments).

63. The authorities recently adopted a revised capital adequacy regulation that will take full effect on August 1, 2013. This change was made with a view to strengthen the quality of capital by incorporating some of the Basel III recommendations. The proposed capital regulation would include: (i) a minimum Tier I capital of 4.5 percent of risk weighted assets; (ii) deduction of goodwill from Tier I capital with a grandfathering clause; (iii) some restrictions for the inclusion of voluntary reserves and current profits, to include only those that are expected to be permanent; and (v) amendments on the consideration of minority interests to mitigate the risk of multiple leveraging. In addition to this reform already underway, it is recommended that the authorities consider their adherence to one of the Basel standards and, in the medium term, the adoption of the Pillar two of Basel II.

64. The SFC has a robust framework for the supervision of several individual risks, albeit some gaps need to be addressed. The SFC has issued norms containing the standards for risk management of financial institutions (referred to as SARs for its initials in Spanish) on credit, market, liquidity, operational and anti-money laundering risks. The SFC has specialized risk units that have responsibility for the overall supervisory process of each of these risks, including autonomous powers to issue administrative orders and sanctions. The scope of application of the SARs is the individual institutions and the individual risks. There is a general requirement that supervised entities manage their risks in a comprehensive way, but there are no further specifications with regards to the comprehensive risk management of banks and banking groups. Also there are no standards for the management of interest rate in the banking book and country and transfer risks. These latter risks, which were originally considered low priority, have become significant with the expansion of Colombian banking groups abroad.

\section{Asset classification and provisioning regulations and supervision in Colombia are} comprehensive and robust and the SFC seems up to date with market developments. Banks are required to segregate exposures into retail (with sub portfolios for auto loans, credit card loans and others), commercial (with sub portfolio for large, middle and small companies), mortgages and microcredit. Each commercial and retail sub portfolio is required to be classified 
into seven levels of risk (which take into account past due information and other criteria) with increasing levels of provisioning, which are calculated through transition matrixes and encompass a pro-cyclic and a counter-cyclic element. Mortgages and microcredit are provisioned based in past dues and collateral, as well as through a generic provisioning.

\section{Large exposure and related party limits are in place but need to be more} comprehensive and streamlined. Colombia has in place an overly complex set of rules for limiting large exposures. More importantly, local affiliates are not consolidated and available unused credit lines are not taken into account in calculating neither large exposure limits nor related party lending. In addition, for large exposures, a statement under oath of nonrelation can exempt certain parties from the definition of connected parties. The SFC is also recommended to require that exposures to directors, senior management and key staff, their direct and related interests, and their close family in affiliated companies also comply to the limits for related party lending, as well as require banks to have policies in place to prevent persons benefiting directly or indirectly from the exposure from being a part of the process of granting and managing the exposure.

67. The SFC has a robust framework for AMLTF and for addressing criminal activities but actual oversight of its implementation by banks must be enhanced. The SFC has a clear scope of activities and seems well versed and up to date with recent developments on the matter. The legal framework, together with the SAR and other regulations set a clear and robust guidance for the allocation of functions and responsibilities for the processes and controls oversight, reporting suspicious activities for banks operating in Colombia. Nevertheless, the actual monitoring of the effectiveness of banks' policies and processes, including strict KYC, in preventing banks from being used, intentionally and/or unintentionally needs to be enhanced.

\section{Methods of ongoing banking supervision (CPs 19-21)}

\section{The SFC is in process of strengthening its supervisory approach, which should} significantly enhance its ability to maintain a thorough understanding of the risk profile of banks and banking groups. The approach adopted by the SFC after the merger of the securities insurance and banking superintendence's has resulted in quasi-autonomous risk areas planning and performing supervision oversight with lack of coordination and a limited consolidated and strategic view of each bank/conglomerate risk profile. Acknowledging such shortcomings, the SFC initiated a restructuring process, which started by developing a risk-based supervisory annual plan, which has already resulted in increasing coordination among the various areas. Among the next planned steps is the establishment of an actual relationship manager, which can be of significant help in insuring that the SFC has a thorough understanding of the risk profile of banks and banking groups. The SFC is also working on the implementation of a risk based supervisory approach called Marco Integral de Supervision (MIS). Once fully implemented, the MIS together with the establishment of a relationship manager will contribute to ensure more consistency in quality and depth of reports among the various areas, as well as a move towards less compliance focused and more conclusive reports. 
Accounting and disclosure (CP 22)

69. Currently, the accounting standards applicable for banking institutions have some deviations from international standards, some of them on the prudent side and some of them on the lax side. On the prudent side, provisions are based on the sum of incurred loss plus an estimation of probable loss reflected in the countercyclical component and some items (such as brands) cannot be included in the goodwill. Deviations on the lax side include: various deferred charges, the amortization of goodwill, guarantees issued and labor and pension benefits. Also disclosures on related party and minority interest are not according to IAS. Under IAIS banks would need to identify transactions with indirect related parties and whether a minority interest is in fact minority interest. External audit norms are currently rather general and do not cover all the aspects of the international audit standards. While the SFC has the authority to oversee external auditors, it needs to adopt more rigorous standards for independence. For example, an auditor can receive as much as $25 \%$ of its revenues from non-audit services from a firm it audits without being disqualified and disqualifications appear to only apply to the term of the specific engagement.

70. Colombia has initiated a process of convergence toward International Financial Reporting Standards and Auditing standards. The general framework was issued in 2009 (Law 1314) but full implementation needs additional regulation to be issued by the MoF and the Ministry of Commerce. The process is currently in a stage of voluntary testing, by which some entities (only two of them are banks) have announced to the SFC that they will participate in the testing, which implies that they will prepare their 2012 opening balance under IFRS. The SFC is assessing the best way to move to IFRS and there is a tentative plan to adopt this by 2014 . However, the SFC has not yet published a timetable for implementation of IFRS.

\section{Corrective and remedial powers of supervisors (CP 23)}

71. The SFC has a broad range of preventive and corrective powers and there is ample evidence of their effective use. Early on, the SFC can issue administrative orders, moral suasion, cease and desist orders and sanctions. The sanctioning process is rather lengthy and time consuming. Thus, in order to be more effective, the SFC has adopted a more proactive policy of issuing administrative orders early on, as soon as the risk of a potential violation is detected. Administrative orders are, therefore, the preferred course of action of the SFC to correct risky behavior and unsafe practices. For more serious problems the SFC has a comprehensive range of bank resolution tools and triggers that set in motion decisions with regards to the problem institution.

Consolidated and cross-border banking supervision (CPs 24-25)

72. The consolidated supervision of financial conglomerates has been significantly enhanced since the creation of the SFC. Improvements in the legal framework have empowered the SFC to conduct onsite exams and obtain necessary information from not 
supervised members of financial conglomerates, to order the consolidation of financial statements of companies of these conglomerates, to exchange information with foreign supervisors and to authorize investments in the capital of foreign entities. Supervisory procedures are in place and a dedicated team is responsible for the supervision of financial conglomerates. The scope of the analysis covers the financial conglomerate, as well as the broader mixed conglomerate.

\section{In spite of this progress, there are key issues which hinder the effectiveness of the consolidated supervision performed by the SFC, such as:}

- $\quad$ There is no regulation that frames the consolidated supervision activities of the SFC, only general references in the law and regulations covering reporting requirements on consolidated financial statements, access to information, consolidated exposure limits and a consolidated capital requirement. There are no risk management requirements on a consolidated level, besides limited references in some of the SAR resolutions.

- $\quad$ The legal powers of the SFC with regards to effective consolidated supervision are narrow, as they only cover supervised entities and their subsidiaries, leaving out the unregulated bank holding companies. So consolidated supervision, capital requirements and exposure limits are applied from the bank down and only cover supervised entities.

- $\quad$ The scope of the consolidated prudential requirements is incomplete and uneven (some exclude domestic subsidiaries, others exclude foreign subsidiaries). The regulation should be amended to correct this problem.

- $\quad$ The SFC lacks powers to force changes in the group's structure if it is inadequate, albeit it has succeeded in a few cases using moral suasion.

74. The SFC has established an effective network of cooperation for the purposes of consolidated supervision of the financial conglomerates that operate in Colombia. There are no legal limitations for the supervisory cooperation. The SFC has signed MoU with most of the home and host supervisors of these conglomerates, which are published in the SFC web page. It engages in regular exchanges of information with these agencies. The SFC has organized the two colleges of supervisors, one with Banco de Bogota with the participation of six foreign supervisory agencies, which had its first meeting in January 2012, and another one with Bancolombia on November 2012, with the participation of supervisory agencies from Central America. The SFC has also become a member of the Central American Council of Banking Supervisors (CCSB), which is an effective forum for the coordination with the most of the host supervisors of the three largest Colombian groups. 


\section{Table 4. Colombia: Summary Compliance with the Basel Core Principles- Detailed Assessments}

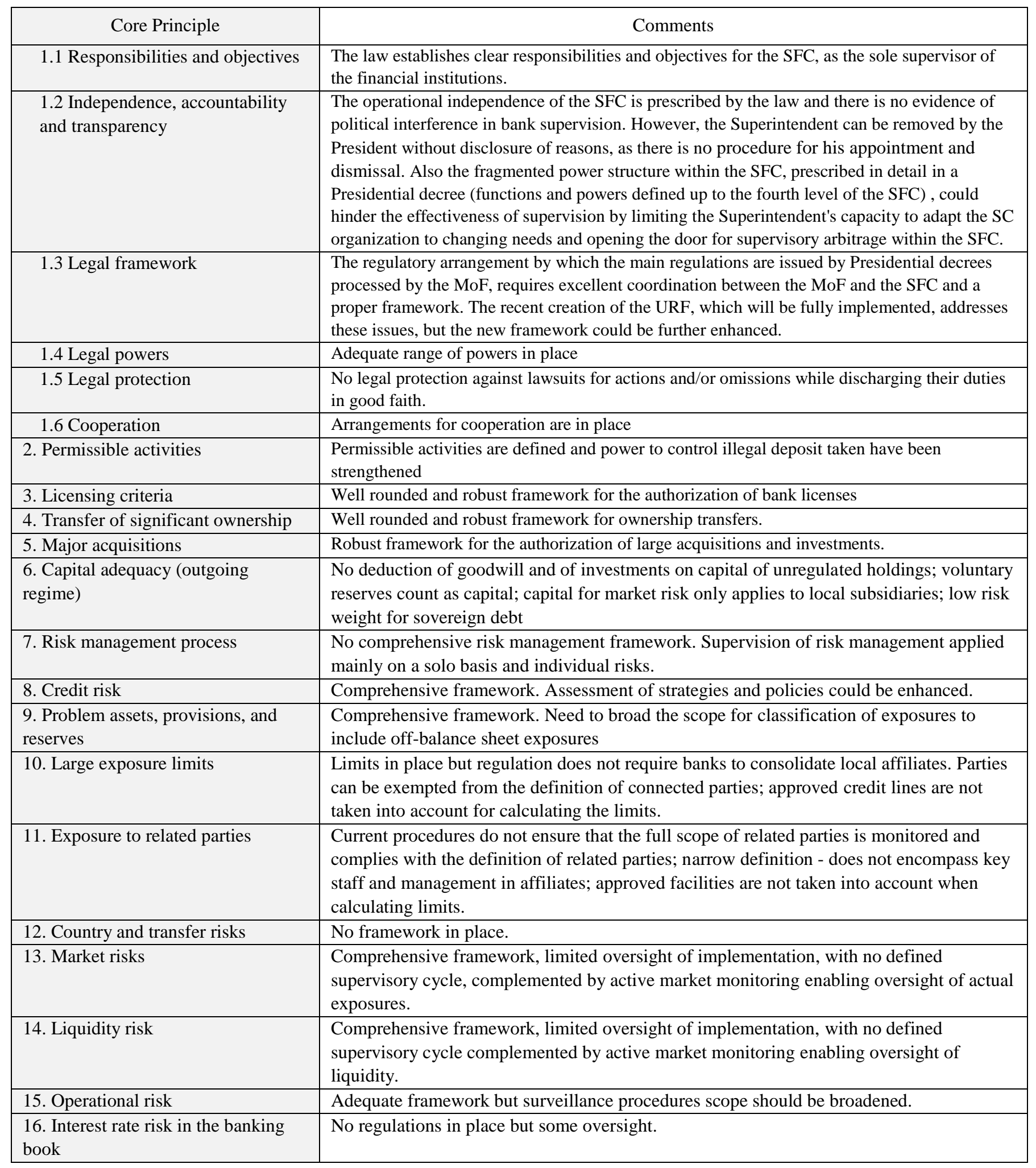




\begin{tabular}{|c|c|}
\hline 17. Internal control and audit & $\begin{array}{l}\text { Adequate framework in place but need no overall assessment; need to broaden the internal } \\
\text { audit oversight to encompass outsourced activities. }\end{array}$ \\
\hline 18. Abuse of financial services & Robust framework but oversight of implementation of SARLAFT needs to be enhanced.. \\
\hline 19. Supervisory approach & $\begin{array}{l}\text { Fragmented view of banks' risk profiles, with no proper consolidation of risks and overall } \\
\text { oversight of banks, undermining strategic view and adequate prioritization. }\end{array}$ \\
\hline 20. Supervisory techniques & $\begin{array}{l}\text { Off-site and on-site frameworks in place. Reports could be more conclusive and strategic } \\
\text { to allow for fuller knowledge regarding banks operations and risk profile. }\end{array}$ \\
\hline 21. Supervisory reporting & Need to broaden the scope to include information on all risks on a consolidated basis. \\
\hline 22. Accounting and disclosure & $\begin{array}{l}\text { Deviations from IAS on deferred charges, amortization of goodwill, guarantees issued, } \\
\text { labor and pension benefits and the valuation of assets. Also disclosures on related party } \\
\text { and minority interest are not according to IAS. Auditing regulation needs improvement, } \\
\text { especially with regards to the standards for audit independence. }\end{array}$ \\
\hline $\begin{array}{l}\text { 23. Corrective and remedial powers } \\
\text { of supervisors }\end{array}$ & Broad range of preventive and corrective powers and evidence of their effective use. \\
\hline 24. Consolidated supervision & $\begin{array}{l}\text { Regulatory gaps hinder the consolidated supervision of banking groups: legal power only } \\
\text { covers the bank and its subsidiaries, leaving out unregulated holdings and affiliates; no } \\
\text { power to change group structure; prudential requirements do not cover the overall banking } \\
\text { group. }\end{array}$ \\
\hline 25. Home-host relationships & Adequate arrangements for the cooperation with foreign supervisors \\
\hline
\end{tabular}




\section{Table 5. Colombia: Recommended Action Plan to Improve Compliance with the Basel Core Principles}

\begin{tabular}{|c|c|}
\hline Reference Principle & Recommended Action \\
\hline 1.2 Independence, accountability and transparency & $\begin{array}{l}\text { Amend law to establish procedure for the appointment and } \\
\text { removal (with disclosure of reasons) of Superintendent. }\end{array}$ \\
\hline 1.3 Legal framework & $\begin{array}{l}\text { Amend the URF framework to strengthen its independence, } \\
\text { ensure that the SFC maintains a key role in the regulatory } \\
\text { process and find a better balance between regulation of MoF } \\
\text { and Instructions issued by SFC }\end{array}$ \\
\hline 1.5 Legal protection & Amend law to grant legal protection to supervisors \\
\hline 6. Capital adequacy (outgoing regime) & New regime corrects most of the shortcomings of old regime. \\
\hline 7. Risk management process & $\begin{array}{l}\text { Issue instructions and implement comprehensive risk } \\
\text { management framework }\end{array}$ \\
\hline 9. Problem assets, provisions, and reserves & $\begin{array}{l}\text { Strengthen regulation for restructured loans. Require banks to } \\
\text { classify all exposures. }\end{array}$ \\
\hline 10. Large exposure limits & $\begin{array}{l}\text { Eliminate various exceptions; broaden scope to include all } \\
\text { affiliates; ensure the proper application of interconnected } \\
\text { parties; ensure that approved facility lines are taken into } \\
\text { account when calculating limits; streamline the regulation. }\end{array}$ \\
\hline 11. Exposure to related parties & $\begin{array}{l}\text { Clarify the regulation so limits are applied to all exposures to } \\
\text { related parties; broaden the scope; enhance oversight. }\end{array}$ \\
\hline 12. Country and transfer risks & Issue framework and design oversight process. \\
\hline 13. Market risks & Effectively oversight of proper implementation of the SARM. \\
\hline 14. Liquidity risk & Effectively oversight proper implementation of the SARL. \\
\hline 15. Operational risk & Broaden the scope of oversight beyond IT. \\
\hline 16. Interest rate risk in the banking book & Issue framework and design oversight process. \\
\hline 17. Internal control and audit & Develop framework for overall assessment. \\
\hline 18. Abuse of financial services & Effectively oversight proper implementation. \\
\hline 19. Supervisory approach & $\begin{array}{l}\text { Implement intended changes ensuring the establishment of } \\
\text { relationship managers for banks. }\end{array}$ \\
\hline 20. Supervisory techniques & Revamp reports moving toward a more risk-based approach. \\
\hline 21. Supervisory reporting & Ensure information is gathered on a consolidated basis. \\
\hline 22. Accounting and disclosure & $\begin{array}{l}\text { Implementation of IFRS and international auditing standards, } \\
\text { including a higher standard for the independence of external } \\
\text { auditors. }\end{array}$ \\
\hline 24. Consolidated supervision & $\begin{array}{l}\text { Issue regulation to broaden scope of consolidated supervision } \\
\text { and enhance powers of SFC }\end{array}$ \\
\hline
\end{tabular}




\section{Authorities' Comments}

\section{General comments}

75. In 2011, the Colombian government requested that the International Monetary Fund (IMF) and World Bank conduct a comprehensive financial sector assessment, including the specific analysis of standards applicable to the banking, insurance, securities, payment systems, and financial infrastructure provider sectors. In response to the request, IMF and World Bank experts and experienced supervisors from other countries conducted a detailed evaluation of the regulation and supervision of the financial system, the securities markets, their agents, and financial infrastructures during the period from May to July, 2012.

76. The preliminary findings were provided to the authorities for comment, as well as a general summary for publication. It should be noted that the previous assessment of this type in Colombia was conducted at the end of 2004, in a markedly different context insofar as there were two supervisory authorities (the banking and securities superintendencies) responsible for oversight of the entities within the Colombian financial sector.

77. Based on the information provided by the IMF and World Bank in regard to the FSAP findings, Colombia has demonstrated considerable progress in implementing the standards and principles applicable to the regulation and oversight of banks, insurance companies, the securities market, and providers of financial infrastructure. One of the main aspects evaluated was the role of the supervisor. In this area, the assessment recognized that the Colombian Financial Superintendent (SFC) has improved its capacity to fulfill its responsibilities. In particular, the mission underscored the progress of the supervisory mechanism since the merger of the banking and securities superintendencies in the SFC and the enactment of Law 964 of 2005.

78. The mechanism of a single supervisory authority like the SFC serves to cover all financial sectors and activities, ensuring greater transparency and efficiency in terms of regulatory enforcement and eliminating regulatory gaps and arbitrage that may arise when there is more than one supervisory authority.

79. In particular, in regard to oversight of the securities market, the mission noted the fact that the SFC has the authority to access a wide variety of sources of information to evaluate the conduct of the market, its agents, and associated risks, as well as the capacities of market participants. The mission also recognized that the SFC has a comprehensive regulatory framework that appropriately addresses industry risks, and has well-developed supervisory procedures and methodologies. In addition, the mission underscored the regulatory powers granted to the SFC to take preventive and corrective measures and impose sanctions, including much broader powers than are accorded supervisors in developed countries. The mission also recognized that the SFC staff were quite professional and competent and were becoming increasingly expert in conducting risk-based supervision, thereby meeting the challenges presented by the new international standards and guidelines. 
80. The FSAP evaluators recognized the SFC's achievements but also indicated that certain weaknesses persisted and supervision should therefore be strengthened. In this regard, they noted the need to continue working to improve the SFC structure in order to strengthen and make better use of its status as sole supervisor, for example, by reforming its organizational structure - a project the SFC was already working on and would serve to increase its independence; increase efficiency in the performance of its functions and its interactions with the supervised entities; and deepen the oversight of the securities market, particularly in regard to the development and increased use of new products and instruments.

\section{Comments on assessment of the banking sector in accordance with Basel Principles}

81. On the assessment of banking supervision, while we agree with many aspects of this assessment, we would like to offer some clarifications and highlight several areas where our views differ from those expressed in this annex.

82. For quite some time, we have recognized the need to upgrade the definition of bank capital, and since 2011, have been developing the new capital adequacy regime, which was published in August 2012 and will take full effect on August 1, 2013. This revised capital regime will address many of the shortcomings pointed out by this assessment. It is unfortunate that the assessment of banking supervision could not evaluate the new regime, but we understand that the rules of these assessments stipulate that the assessors can only review the regulatory framework in place at the time of the assessment.

83. On the issue of the independence of the SFC, we want to emphasize that, while Colombia's legal and constitutional framework may make it difficult to establish de jure independence, the SFC has full de facto independence. It conducts supervision of the financial system without any political interference whatsoever, and works with the MHCP to develop regulations and other aspects of the legal framework also without political influence or interference.

84. We would also like to feature our close collaboration with the Toronto Center over the past few years, which has greatly strengthened our capacity for risk based supervision and improved the comprehensiveness of risk assessments conducted by the SFC as well as by the financial institutions themselves. We fully expect that this program of technical cooperation will continue to bear fruit in the next several years and to strengthen supervision even further.

85. In regard to principles 2 to 5 it must be included that Decree 4334 of 2008 allows the intervention of the Superintendency of Corporations or the SFC when there are objective or notorious facts that indicate the massive taking of money, directly or indirectly, through a broad variety of schemes. 
86. In regard to principles 6 to 18 , concerning prudential regulation and requirements, the document states: "(...) the risk weight applied for exposures with sovereigns is low and independent of risk (zero the local government and 20 percent for foreign governments)." The low risk weight for sovereign debt is used on many other jurisdictions. In opinion of the SFC, for an entity with peso-denominated financial statements, the investments with the lowest risk are those issued by the Colombian government, weighted at zero percent on the RWA, acknowledging this low risk. Regarding other sovereign debt, almost all of the resources are allocated on highly rated issuers, which is why their weight is 20 percent (being this sometimes higher than the weight recommended by Basel).

87. The SFC propose the following statement be included on the end of paragraph 14 instead of paragraph 13: "In addition to the reforms already being planned, it is recommended that the authorities consider their adherence to one of the Basel standards and, in the medium term, the adoption of the Pillar two of Basel II."

88. Also, on paragraph 18, the document states: "The SFC has a robust framework for AMLTF and for addressing criminal activities but actual oversight of its implementation by banks must be enhanced." On this matter is necessary to mention that both in-situ and extra-situ procedures are conducted, according to the criteria defined on the principles. All of the supervised banks have been included into the supervisory cycle on a period no longer than three years, with an exception of one entity with a share of only 0.16 percent of the market. In this case, the supervisory cycle took four years to complete.

89. The oversight procedures are complemented with internal and external auditors and compliance officers. There is also an agreement with the UIAF to identify failures on the reports.

90. Regarding BCP 22, accounting and disclosure, it is important to mention the following: The regulation for NIIF implementation in Colombia was issued on December 28, 2012. Decree 2784 of 2012 establishes that most of the SFC's supervised entities, among other companies, must issue NIIF financial statements starting in 2015, with the following transition and enforcement deadlines:

- $\quad$ Mandatory preparation period: 2013.

- $\quad$ Transition deadline - opening statement: January 1, 2014.

- $\quad$ Enforcement deadline (first comparative): December 31, 2014.

- $\quad$ Reporting deadline - NIIF Financial statements: December 31, 2015.

91. On Table 4. Summary Compliance with the Basel Core Principles-Detailed Assessments, regarding risk management process (7) and supervisory approach (19), the 
SFC has been working on the development of the MIS (Marco Integral de Supervisión), which allows for a consolidated risk assessment of all supervised entities, enabling the strategic view and the prioritization of the supervision.

92. Also on Table 4, regarding Market Risk (13), it is important to mention that the SARM must be implemented by every credit institution, and it is subject to be revised on in-situ inspections conducted by the Deputy Office for Supervision of Market Risk and Integrity.

93. Additionally, given that the measurement model of the market risk must be sent to the SFC on a daily basis, an extra-situ supervision takes place with this frequency, using a range of indices and early warnings that allow identifying individual and systemic risks of the portfolios. This measurement includes foreign currency denominated assets.

94. Finally, on Table 4, Liquidity Risk (14), we highlight that the SARL must be implemented by every credit institution, and it is subject to be revised on in-situ inspections conducted by the Deputy Office for Supervision of Market Risk and Integrity.

95. Additionally, given that the measurement model of the liquidity risk, known as IRL (similar to the LCR of Basel III), must be sent to the SFC at least on a weekly basis, an extra-situ supervision over individual and systemic liquidity risk takes place at every time. The IRL includes, among others, the ratio of foreign currency denominated liquid assets. On the other hand, it is important to highlight that the SFC has, apart from the IRL, a wide range of tools for the oversight of liquidity risk: money market operations reports, deposits, interest rates, deposits concentration, liquidity of investments, etc. 


\section{ANNEX II. IOSCO PRINCIPLES-SUMMARY ASSESSMENT}

\section{SumMARY, Key Findings, AND RECOMMENDATIONS}

96. The SFC of Colombia has a highly transparent and comprehensive securities regulatory and supervisory regime. In particular, Colombia has made major progress since the adoption of the new Securities Law in 2005 in developing an integrated financial services authority whose oversight and supervisory activities span the entire financial sector. Further, SFC has an increasingly expert staff dedicated to executing an ambitious program, including the use of external expertise, to meet international standards and develop best practices on an ongoing basis. SFC also has invested heavily in incubating the benefits of its unified structure. Nonetheless, more work is necessary to assure that conduct matters are given sufficient prominence, particularly as a matter of structure, insofar as they interplay with prudential matters, and in the area of enforcement related to market abuses like manipulation. Further, there remain areas related to the supervision/regulation of securities functions where further improvements are in process that could be accelerated. Additionally, the overall structure of the system could be enhanced to increase its independence and its intervention capabilities.

\section{A. Introduction}

97. This assessment was conducted as part of a mission to Bogota, Colombia in May and June 2012.

\section{B. Information and Methodology Used for Assessment}

98. This assessment was conducted using the Assessment Methodology for the IOSCO Objectives and Principles of Securities Regulation adopted in September 2011. Although the assessment makes some general comments about Principle 38, the financial market infrastructure assessment has been completed by a separate assessor.

99. Caution should be applied when comparing the results of this assessment to any previous reviews. Although Colombia has to date weathered the financial crisis well, the rigor and thoroughness of the review cycle of which this review is a part, as well as the increased weight being given to the effective implementation of the various key issues and questions is a product of the heightened interest globally in meeting international standards. In consequence, this assessment is not comparable to prior evaluations. Any changes in ratings from the assessment of 2005 generally do not reflect a decline in the quality or level of regulation; rather they result from increased rigor in the the application of the assessment criteria. 


\section{Main Findings}

100. Principles 1-8, Principles relating to the Regulator. The SFC has taken steps to make the most benefit from its integrated structure that combines prudential and conduct supervision, including bringing its experience to the cross-sectoral financial stability network in matters related to systemic risk, conflicts and policing the perimeter. Nonetheless (a) there are structural impediments to SFC making the most effective use of its resources, b) the structure of the SFC currently does not give sufficient relevance to the conduct function, but this issue will be tackled within the proposed new structure of the SFC;. (c) the institution is distracted by suits assessing liability against the SFC and its staff, (d) work should continue to assure that information flows are not adversely affected by silo-thinking and (e) while very powerful as a matter of day-to-day practice and from the perspective of intervention powers, the lack of a board or a specified term of service for the Superintendencia may compromise, or be perceived to compromise, its independence.

101. Principle 9, Principle for self-regulation. In 2006, a strong self-regulatory institution to which membership is mandatory for intermediaries of all types was created to assist the SFC by acting as the front-line regulator with respect to certification of professionals, market oversight, dispute resolution, complaints handling and for the prevention and sanctioning of conduct inconsistent with the rules of the market by AMV members, pursuant to a memorandum of understanding between the authorities that was concluded in 2007, and for other matters as further agreed. The provisions for oversight of the SRO are strong and there is good cooperation between the authorities. Nonetheless there should be an appeal to the SFC for denial of access to membership in that membership in the SRO is mandatory in order to participate in the industry.

102. Principles 10-12, Principles for the enforcement of securities regulation. The powers

of the SFC with respect to administrative enforcement activities and access to records, statements and testimony are extensive as they pertain not only to regulated institutions, but also to all market participants, and even to non-participant third parties. AMV complements the SFC powers, which include disgorgement, and has undertaken an active disciplinary program that assesses credible, dissuasive and proportionate sanctions. The law and decrees clearly sets forth the sanctioning process. Nonetheless, there remains the perception that enforcement is sometimes an unduly lengthy process. While recognizing the length and depth required for proper investigation of certain types of complex misconduct; more efforts/resources should be expended to combat fraud and market abuse. The SFC, as augmented by the AMV program, has active monitoring and disciplinary programs, but action to deter misconduct could proceed more quickly, sanctions could be stronger and more "message" cases could be selected for their deterrent purposes.

103. Principles 13-15, Principles for cooperation in regulation. SFC was just this May admitted to Annex A of IOSCO's MMoU, the gold standard of information sharing. The SFC does actively cooperate and provide and receive information under its various arrangements which are designed to give priority to those jurisdictions which are linked with Colombia. 
104. Principles 15-18, Principles for Issuers. Standards for issuance of securities and related disclosure are high, however in the governance area, although progress has been made, there are still substantial gaps in the protections accorded minority shareholders and potential gaps in the information as to who has the capacity to influence the decisions of financial entities within conglomerates (see also Principles on Intermediaries).

\section{Principle 19-23, Principles for auditors, credit rating agencies, and other}

information service providers. The SFC has adopted the international best practice with respect to rating agencies and has even brought enforcement actions, it has preceded the development of international standards in working toward more independent pricing methodologies for securities for which there is not an active market. In September 2012, after the IOSCO assessment was conducted, the SFC issued a timetable for bringing its accounting and auditing standards up to the standard of international practice and its local standards are not in practice of international quality.

106. Principles 24-28, Principles for collective investment schemes. The rules for those schemes that fall within the definition of carteras colectivas are comprehensive and meet IOSCO standards. There is however the possibility that certain trusts may operate trusts with multiple participants that are not truly private offers, which while subject to regulation have a lesser standard than would a collective investment offering similar types of financial products.

107. Principles 29-32, Principles for market intermediaries. SFC treats all intermediaries substantially equivalently, applying the prudential, risk and conduct regimes to each. However, there have been cases where intermediaries have assumed excessive exposures, and more thought could be given as to how to address at the SFC level the failures of firms and other disruptions.

108. Principles 33-37, Principles for the Secondary Markets. The markets and trading systems of Colombia meet international standards with respect to transparency, including the reporting of over-the-counter transactions, and the rules for market abuse, although with multiple systems for the same securities, some consideration should be given to further consolidating price reporting. Additionally, the SFC has impressive ability to intervene to address disruption and excellent real-time facilities to address surveillance for misconduct, with strong proprietary systems for identifying trading exceptions. Due to how trading and settlement is organized on multiple systems and orders are entered, the SFC should be careful to have appropriate measures in place to ensure that any trading within the settlement period does not result in misallocation of customer transactions in the clearing and settlement process, or insufficient collateral to address the potential risks and that nonprofessional clients in fact receive best execution. 
Table 6. Colombia: Summary Implementation of the IOSCO Principles

\begin{tabular}{|c|c|}
\hline Principle & Findings \\
\hline $\begin{array}{l}\text { Principle } 1 \text {. The responsibilities of the Regulator should } \\
\text { be clear and objectively stated. }\end{array}$ & $\begin{array}{l}\text { The legislation, decrees, secondary norms, and } \\
\text { guidance that affect securities regulation/supervision } \\
\text { are all public and available on either the website of the } \\
\text { SFC or the MoF or other government-wide websites. } \\
\text { In } 2005 \text { a regulator that unified prudential and conduct } \\
\text { regulation was created merging banking and insurance } \\
\text { with securities, including collective investments and } \\
\text { pensions. } \\
\text { Nonetheless, legal integration does not automatically } \\
\text { result in operational integration. } \\
\text { More work can be done to assure appropriate flows of } \\
\text { information related to separate prudential and conduct } \\
\text { supervision methodologies to assure coverage of all } \\
\text { risks within supervised entities and of the channels for } \\
\text { transmission of risks. Further the structure of the SFC } \\
\text { may diminish the importance of conduct issues, albeit } \\
\text { conduct matters are also addressed through the AMV. } \\
\text { The SFC is aware of these coordination issues and is } \\
\text { working actively to enhance information flows within } \\
\text { the institution. } \\
\text { See Principle } 24 \text { with respect to a possible gap related } \\
\text { to the oversight of non-mutual fund fidiecomisos. }\end{array}$ \\
\hline $\begin{array}{l}\text { Principle } 2 . \text { The Regulator should be operationally } \\
\text { independent and accountable in the exercise of its } \\
\text { functions and powers. }\end{array}$ & $\begin{array}{l}\text { By law the SFC is an autonomous, technical agency, } \\
\text { which is self-financed subject to general rules with } \\
\text { respect to budget accountability and fiscal restraint. } \\
\text { It has substantial powers to take supervisory, } \\
\text { enforcement and information sharing action without } \\
\text { consulting with other authorities or seeking their } \\
\text { approval and there is no evidence of political or } \\
\text { commercial interference with day-to-day operations.. } \\
\text { However, the governance structure, which uses a non- } \\
\text { binding advisory committee and a single } \\
\text { Superintendente, both of which serve at will of the } \\
\text { President may at best compromise the perception of } \\
\text { independence, and at worst, its actuality. } \\
\text { Further protections from suits related to the } \\
\text { performance of the SFC mandates in good faith would } \\
\text { curtail the distraction of numerous lawsuits, even } \\
\text { though the case law provides some protection for } \\
\text { actions taken in good faith. For example, good faith } \\
\text { might be further defined to mean not in bad faith. } \\
\text { New resources for the MoF related to the development } \\
\text { of regulation are intended to retain appropriate input } \\
\text { by SFC and from the supervisory process, but could } \\
\text { potentially raise issues related to interference with day- } \\
\text { to-day oversight/supervisory operations. }\end{array}$ \\
\hline
\end{tabular}




\begin{tabular}{|c|c|}
\hline Principle & Findings \\
\hline $\begin{array}{l}\text { Principle } 3 \text {. The Regulator should have adequate } \\
\text { powers, proper resources and the capacity to perform its } \\
\text { functions and exercise its powers. }\end{array}$ & $\begin{array}{l}\text { The SFC has a stable workforce with strong } \\
\text { professional credentials in financial-related disciplines, } \\
\text { economics, and the law, and a low level of turnover. It } \\
\text { has a strong training and a strong financial literacy and } \\
\text { consumer responsiveness program as well. The } \\
\text { securities function, although augmented by AMV, } \\
\text { could use additional, dedicated resources. } \\
\text { The codification of the organization chart with explicit } \\
\text { mandates granted down several tiers of management } \\
\text { could compromise allocation of resources, flexibility } \\
\text { in addressing evolving market issues, and potentially } \\
\text { interfere with the ability to obtain a holistic view of } \\
\text { supervised entities. } \\
\text { Insufficient prominence is given in the mandated } \\
\text { structure to the oversight of the conduct function and } \\
\text { the integration of conduct related concerns into to the } \\
\text { overall risk-basing applied to supervised entities. (See } \\
\text { also Principle 1). } \\
\text { SFC leadership does, however, use the authority it has } \\
\text { creatively and can and does appoint working groups } \\
\text { that transcend the mandated organization chart } \\
\text { groupings. SFC is also in the process of making } \\
\text { committed efforts to assure the appropriate disciplines } \\
\text { are brought to bear on each supervisory issue and to } \\
\text { each type of institution subject to supervision and that } \\
\text { information flows are optimized. }\end{array}$ \\
\hline $\begin{array}{l}\text { Principle } 4 \text {. The Regulator should adopt clear and } \\
\text { consistent regulatory processes. }\end{array}$ & $\begin{array}{l}\text { SFC has strong, clear, documented regulatory } \\
\text { processes, that have been certified pursuant to the ISO } \\
\text { standards and which are carefully followed. } \\
\text { The application of the rules and procedures are } \\
\text { transparent, and the consultation process is being } \\
\text { enhanced to provide more feedback relative to the } \\
\text { comments received. The SFC website is } \\
\text { comprehensive and the site map is easy to navigate, } \\
\text { with information on the rules, on supervised entities, } \\
\text { on issuers, corporate governance, and myriad other } \\
\text { matters. All regulatory actions against individuals must } \\
\text { be reasoned with the reasons given in writing and all } \\
\text { sanctions, once final, are public. } \\
\text { The lack of more information in English may impede } \\
\text { some participation in the markets as Colombian } \\
\text { markets are opened more broadly to global } \\
\text { participants. Additional feedback on comments would } \\
\text { be welcomed. }\end{array}$ \\
\hline
\end{tabular}




\begin{tabular}{|l|l|}
\hline Principle & Findings \\
\hline $\begin{array}{l}\text { Principle 5. The staff of the Regulator should observe } \\
\text { the highest professional standards, including appropriate } \\
\text { standards of confidentiality. }\end{array}$ & $\begin{array}{l}\text { The SFC has, and applies, its own Code of } \\
\text { Governance, Ethics Code, and rules relating to } \\
\text { conflicts of interest as well as internal organs, } \\
\text { including internal audit functions to enforce these. } \\
\text { Staff cannot own securities and confidentiality } \\
\text { provisions are strong. } \\
\text { Monitoring procedures are in place and monitoring } \\
\text { occurs. }\end{array}$ \\
\hline $\begin{array}{l}\text { Principle 6. The Regulator should have or contribute to } \\
\text { a process to monitor, mitigate and manage systemic } \\
\text { risk, appropriate to its mandate. }\end{array}$ & $\begin{array}{l}\text { The SFC is a full participant on the cross-sectoral } \\
\text { financial stability authority that includes the Central } \\
\text { Bank and Fogafin. The CCSSF has had an active work } \\
\text { program dedicated to developing early warning, } \\
\text { information protocols for routine and crisis situations, } \\
\text { and resolution mechanisms since the crises of the late } \\
\text { nineties. The adaptation of the committee to current G- } \\
\text { 20 guidance is well underway but can be further } \\
\text { augmented. The current process feeds information on } \\
\text { micro-supervision activities and macro-prudential } \\
\text { environmental concerns into ongoing discussions. For } \\
\text { example, at the micro level, market and liquidity risks } \\
\text { are reviewed on a daily and monthly basis with the } \\
\text { view to identifying interconnections that could } \\
\text { potentially be systemic. The group has considered } \\
\text { recent market events such as the loss in value of } \\
\text { certain European jurisdiction's debt, and inflows and } \\
\text { outflows of money. More information on the inter- } \\
\text { relationships of conglomerates within Colombia might } \\
\text { assist in addressing potential systemic concerns. More } \\
\text { work could also be conducted relative to the potential } \\
\text { for failures to originate from the securities sector. }\end{array}$ \\
\hline
\end{tabular}




\begin{tabular}{|c|c|}
\hline Principle & Findings \\
\hline $\begin{array}{l}\text { Principle } 7 \text {. The Regulator should have or contribute to } \\
\text { a process to review the perimeter of regulation } \\
\text { regularly. }\end{array}$ & $\begin{array}{l}\text { The SFC has recently obtained augmented power to } \\
\text { address issues and products that potentially could have } \\
\text { fallen without the perimeter of financial sector } \\
\text { regulation; in effect, the SFC now has added } \\
\text { competence to address conduct related to the taking of } \\
\text { money under any circumstances, including through the } \\
\text { real sector that might result in risk of losses to } \\
\text { customers. There also is now a program of enhanced } \\
\text { communications among the different parts of the SFC } \\
\text { about emerging issues. } \\
\text { Additionally, the SFC received increases in staff to } \\
\text { explore further measures to identify activity taking } \\
\text { place outside the supervised environment that could } \\
\text { constitute the illegal offer of securities and enhanced is } \\
\text { operating arrangements with the Superintendente de } \\
\text { Sociedades. } \\
\text { Nonetheless, neither the SFC nor the CCSSF seem to } \\
\text { have an explicit "top-down" procedure to identify and } \\
\text { address the emergence of new conduct risks or } \\
\text { unregulated conduct that could have prudential } \\
\text { implications, nor are the processes clear as to how the } \\
\text { SFC addresses the identification of unauthorized } \\
\text { business, though in practice SFC has shut down } \\
\text { unauthorized businesses. } \\
\text { (See also Principle } 2 \text { - the enhanced role of MoF in } \\
\text { regulation should not prevent continued input from the } \\
\text { supervisory to the regulatory process. }\end{array}$ \\
\hline $\begin{array}{l}\text { Principle } 8 \text {. The Regulator should seek to ensure that } \\
\text { conflicts of interest and misalignment of incentives are } \\
\text { avoided, eliminated, disclosed or otherwise managed. }\end{array}$ & $\begin{array}{l}\text { SFC rules and the LMV contain a full complement } \\
\text { related to preventing, mitigating, disclosing, and } \\
\text { monitoring of conflicts of interest. These are discussed } \\
\text { under each of the functional Principles below, in the } \\
\text { detailed report, and apply to issuers as well as to other } \\
\text { supervised financial entities. } \\
\text { There is evidence that SFC's on-site, off-site and other } \\
\text { programs take account of conflicts and that such } \\
\text { conflicts are considered in developing alerts and } \\
\text { exception reports. }\end{array}$ \\
\hline
\end{tabular}




\begin{tabular}{|c|c|}
\hline Principle & Findings \\
\hline $\begin{array}{l}\text { Principle } 9 \text {. Where the regulatory system makes use of } \\
\text { Self-Regulatory Organizations (SROs) that exercise } \\
\text { some direct oversight responsibility for their respective } \\
\text { areas of competence, such SROs should be subject to } \\
\text { the oversight of the Regulator and should observe } \\
\text { standards of fairness and confidentiality when } \\
\text { exercising powers and delegated responsibilities. }\end{array}$ & $\begin{array}{l}\text { The AMV was created in 2006. It is a self-regulatory } \\
\text { institution in which all supervised entities must hold a } \\
\text { membership and in which most of the foreign currency } \\
\text { trade professionals participate voluntarily. } \\
\text { Consideration is being given to expanding the AMV to } \\
\text { other types of professionals if these are created in law, } \\
\text { such as financial advisors. } \\
\text { AMV runs an active surveillance, inspection, } \\
\text { investigation, disciplinary, complaints handling and } \\
\text { dispute regulation program subject to substantial } \\
\text { oversight by the SFC and is the front line regulator for } \\
\text { the prevention and sanctioning of market abuses and } \\
\text { other misconduct. AMV is subject to all rules, } \\
\text { including those relating to conflicts and professional } \\
\text { conduct as are any supervised entity within Colombia. } \\
\text { The governance structure includes industry members } \\
\text { and independent members selected by the industry. } \\
\text { AMVs governance structure and independence have } \\
\text { raised some questions and are under discussion. }\end{array}$ \\
\hline $\begin{array}{l}\text { Principle } 10 \text {. The Regulator should have comprehensive } \\
\text { inspection, investigation and surveillance powers. }\end{array}$ & $\begin{array}{l}\text { The SFC has comprehensive powers to inspect } \\
\text { supervised entities, to follow records from brokerage } \\
\text { to bank accounts, and to conduct continuing real time } \\
\text { surveillance of market activities. The SFC conducts } \\
\text { both on-site and off-site activities based on risk-basing, } \\
\text { themes, programmed alerts, and ad hoc identification } \\
\text { of issues and otherwise. Both on-site and off-site } \\
\text { activities occur in accordance with an annual plan } \\
\text { which reflects information developed during the } \\
\text { preceding year and on an ongoing basis. }\end{array}$ \\
\hline $\begin{array}{l}\text { Principle } 11 \text {. The Regulator should have comprehensive } \\
\text { enforcement powers. }\end{array}$ & $\begin{array}{l}\text { The SFC has comprehensive investigative powers and } \\
\text { sanctioning powers, including the power to } \\
\text { administratively sanction, to obtain statements under } \\
\text { oath, and to freeze and seize assets of parties, } \\
\text { including parties that are not supervised entities. (See } \\
\text { also Principle 12) }\end{array}$ \\
\hline $\begin{array}{l}\text { Principle } 12 . \text { The regulatory system should ensure an } \\
\text { effective and credible use of inspection, investigation, } \\
\text { surveillance and enforcement powers and } \\
\text { implementation of an effective compliance program. }\end{array}$ & $\begin{array}{l}\text { The SFC and the AMV have an active enforcement } \\
\text { program that includes the whole chain of enforcement } \\
\text { activities and a full spectrum of administrative and } \\
\text { criminal sanctions. The program could be benefited by } \\
\text { the creation of a separate enforcement function to } \\
\text { coordinate efforts, and by further efforts to increase the } \\
\text { promptness and sufficiency of sanctioning procedures. } \\
\text { Currently, administrative procedures may be more } \\
\text { timely and effective than criminal procedures. }\end{array}$ \\
\hline $\begin{array}{l}\text { Principle } 13 . \text { The Regulator should have authority to } \\
\text { share both public and non-public information with } \\
\text { domestic and foreign counterparts. }\end{array}$ & $\begin{array}{l}\text { The SFC has full authority to share information with } \\
\text { other domestic authorities and international authorities, } \\
\text { both via an Moue and in certain circumstances even } \\
\text { without one. }\end{array}$ \\
\hline
\end{tabular}




\begin{tabular}{|c|c|}
\hline Principle & Findings \\
\hline $\begin{array}{l}\text { Principle 14. Regulators should establish information } \\
\text { sharing mechanisms that set out when and how they } \\
\text { will share both public and non-public information with } \\
\text { their domestic and foreign counterparts. }\end{array}$ & $\begin{array}{l}\text { In addition to the IOSCO MMoU, SFC has practical, } \\
\text { surveillance-type information sharing arrangements } \\
\text { with Peru and Chile to support the MILA initiative; } \\
\text { arrangements with the jurisdictions in which Colombia } \\
\text { intermediaries have parents or important affiliates, and } \\
\text { is working on obtaining others. SFC also has important } \\
\text { domestic information sharing arrangements, which as } \\
\text { the result of the initiatives to combat systemic risk and } \\
\text { illegal, unauthorized conduct are currently in the } \\
\text { process of being refined and improved. (See also } \\
\text { Principles } 1 \text { and 6) }\end{array}$ \\
\hline $\begin{array}{l}\text { Principle } 15 \text {. The regulatory system should allow for } \\
\text { assistance to be provided to foreign Regulators who } \\
\text { need to make inquiries in the discharge of their } \\
\text { functions and exercise of their powers. }\end{array}$ & $\begin{array}{l}\text { The SFC has met all the requirements to sign Annex A } \\
\text { of the IOSCO MMoU and in fact actively shares } \\
\text { information for fitness and enforcement purposes. }\end{array}$ \\
\hline $\begin{array}{l}\text { Principle } 16 \text {. There should be full, accurate and timely } \\
\text { disclosure of financial results, risk and other } \\
\text { information that is material to investors' decisions. }\end{array}$ & $\begin{array}{l}\text { The SFC has a comprehensive disclosure regime by } \\
\text { prospectus for public issuers. All such issues must be } \\
\text { approved by the SFC and also are exposed in the } \\
\text { registry before they are offered. All listed issuers, } \\
\text { whether or not they are majority government owned } \\
\text { must file the required information. The disclosure } \\
\text { requirement includes all the elements listed by IOSCO } \\
\text { current within } 3 \text { months and as well as a general duty } \\
\text { to disclose anything material to an investment } \\
\text { decision. Financial information (unaudited) must be } \\
\text { reported quarterly within } 30 \text { days of quarter end. All } \\
\text { registered issuers must also provided updates of } \\
\text { relevant information on a continuing basis. } 55 \text { types of } \\
\text { relevant information are specified. Some information } \\
\text { required by IOSCO for cross border listings with } \\
\text { respect to directors and officers is accessible but not } \\
\text { explicitly required. }\end{array}$ \\
\hline
\end{tabular}




\begin{tabular}{|c|c|}
\hline Principle & Findings \\
\hline $\begin{array}{l}\text { Principle } 17 \text {. Holders of securities in a company should } \\
\text { be treated in a fair and equitable manner. }\end{array}$ & $\begin{array}{l}\text { The SFC has made a tremendous effort to improve } \\
\text { corporate governance, adopting a voluntary code, } \\
\text { issuing a yearly report on "compliance," and related } \\
\text { explanations, by all affected companies and requiring } \\
\text { company compliance reports to be public information. } \\
\text { The law applicable to corporate conduct is largely } \\
\text { commercial/company law. The protections of minority } \\
\text { shareholders in the concentrated institutions of } \\
\text { Colombia appear to be more limited than desirable and } \\
\text { the time frames for notice of extraordinary actions and } \\
\text { the AGM are extremely short although IOSCO } \\
\text { provides no specific guidance. The complexity of } \\
\text { Colombia companies makes these deficiencies } \\
\text { especially problematic, as there are assertions that the } \\
\text { protections that are available have been circumvented } \\
\text { by various strategies in practice. }\end{array}$ \\
\hline $\begin{array}{l}\text { Principle } 18 \text {. Accounting standards used by issuers to } \\
\text { prepare financial statements should be of a high and } \\
\text { internationally acceptable quality. }\end{array}$ & $\begin{array}{l}\text { The issue in Colombia is accounting practices. } \\
\text { The SFC currently uses Colombian GAAP. The } \\
\text { accounting reports that are produced in terms of } \\
\text { format, type and timeliness meet IOSCO standards. } \\
\text { The rules require consistent, clear, relevant, reliable, } \\
\text { and comparable results and the SFC has required } \\
\text { reporting formats to increase comparability. Periodic } \\
\text { reports are timely, and, in fact, exceed international } \\
\text { standards; } 30 \text { days after quarter end and } 60 \text { days after } \\
\text { year end for audited reports. However, there is } \\
\text { evidence that application of the current national } \\
\text { standards is weak in practice. Further although SFC } \\
\text { has done a project to determine how best to move to } \\
\text { IFRS and has assessed the capacity of the industry to } \\
\text { comply, it finds that accounting capacity is not } \\
\text { sufficient, it has not yet published a timetable for } \\
\text { implementation and this has created uncertainty in the } \\
\text { issuer and the intermediary community. }\end{array}$ \\
\hline $\begin{array}{l}\text { Principle 19. Auditors should be subject to adequate } \\
\text { levels of oversight. }\end{array}$ & $\begin{array}{l}\text { SFC has the authority to oversee audit performance by } \\
\text { external auditors of supervised entities; real sector } \\
\text { companies are under the remit of the Superintendente } \\
\text { de Sociedades. Colombia does look to IFAC for } \\
\text { guidance on peer reviews and other matters. The } \\
\text { Codigo Pais also establishes some standards, although } \\
\text { these are not uniformly implemented. A more } \\
\text { comprehensive approach to oversight is pending but } \\
\text { has yet to be implemented and audit practices remain } \\
\text { weak. }\end{array}$ \\
\hline
\end{tabular}




\begin{tabular}{|c|c|}
\hline Principle & Findings \\
\hline $\begin{array}{l}\text { Principle } 20 \text {. Auditors should be independent of the } \\
\text { issuing entity that they audit. }\end{array}$ & $\begin{array}{l}\text { SFC applies some independence standards but they are } \\
\text { not as rigorous as those agreed by IOSCO. In } \\
\text { particular there is no specific requirement, other than } \\
\text { in the voluntary code on non-audit services. An auditor } \\
\text { can receive as much as } 25 \% \text { of its revenues from non- } \\
\text { audit services from a firm it audits without being } \\
\text { disqualified and disqualifications appear to only apply } \\
\text { to the term of the specific engagement. }\end{array}$ \\
\hline $\begin{array}{l}\text { Principle } 21 \text {. Audit standards should be of a high and } \\
\text { internationally acceptable quality. }\end{array}$ & $\begin{array}{l}\text { Progress on adopting international auditing standards } \\
\text { lags progress on adopting and implementing } \\
\text { accounting standards and local standards are not of } \\
\text { international quality. }\end{array}$ \\
\hline $\begin{array}{l}\text { Principle } 22 \text {. Credit rating agencies should be subject to } \\
\text { adequate levels of oversight. The regulatory system } \\
\text { should ensure that credit rating agencies whose ratings } \\
\text { are used for regulatory purposes are subject to } \\
\text { registration and ongoing supervision. }\end{array}$ & $\begin{array}{l}\text { SFC has conformed its oversight to IOSCO guidance. } \\
\text { It has an authorization program, publishes rating } \\
\text { methodologies, undertakes active oversight, requires } \\
\text { publication of each product's rating history, and has } \\
\text { even taken enforcement actions. }\end{array}$ \\
\hline $\begin{array}{l}\text { Principle } 23 \text {. Other entities that offer investors } \\
\text { analytical or evaluative services should be subject to } \\
\text { oversight and regulation appropriate to the impact their } \\
\text { activities have on the market or the degree to which the } \\
\text { regulatory system relies on them. }\end{array}$ & $\begin{array}{l}\text { Colombia does not now have a separate category of } \\
\text { financial advisors. Advisory services are offered } \\
\text { within intermediaries of various types. As such they } \\
\text { are subject to the oversight and conflicts provisions of } \\
\text { the intermediary which offers them. The plan in } \\
\text { process to provide authorized price providers, subject } \\
\text { to SFC oversight, to assist in the valuation of illiquid } \\
\text { securities is admirable. In fact two providers have been } \\
\text { registered to date under existing law, subject to further } \\
\text { guidance on the process. However, a question exists as } \\
\text { to whether pricing aberrations and inconsistencies } \\
\text { among like products will occur as the result of multiple } \\
\text { official providers. The SFC is aware of this risk and is } \\
\text { considering how to address it. }\end{array}$ \\
\hline $\begin{array}{l}\text { Principle } 24 \text {. The regulatory system should set standards } \\
\text { for the eligibility, governance, organization and } \\
\text { operational conduct of those who wish to market or } \\
\text { operate a collective investment scheme. }\end{array}$ & $\begin{array}{l}\text { Collective investments, known as carteras colectivas, } \\
\text { the largest value of which are organized as } \\
\text { fideicomisos or trusts, are all subject to a full } \\
\text { complement of requirements relative to disclosure, } \\
\text { authorization and operation. The operator, distributor } \\
\text { and manager must all be authorized and registered The } \\
\text { process of authorization involves a review of the } \\
\text { organizational capacity, governance and resources of } \\
\text { the operator and the reglament of the offering. } \\
\text { Sociedades fiduciaries may offer some collective } \\
\text { offerings that are not considered carteras colectivas, } \\
\text { which investments are subject to different rules, and in } \\
\text { some cases this may raise confusion as to what } \\
\text { regulatory provisions apply. (See also Principles } 1,7 \\
\text { and 28) }\end{array}$ \\
\hline
\end{tabular}




\begin{tabular}{|c|c|}
\hline Principle & Findings \\
\hline $\begin{array}{l}\text { Principle } 25 \text {. The regulatory system should provide for } \\
\text { rules governing the legal form and structure of } \\
\text { collective investment schemes and the segregation and } \\
\text { protection of client assets. }\end{array}$ & $\begin{array}{l}\text { CIS can be structured as open end, closed end, or } \\
\text { escalonadas which combine the features of both. The } \\
\text { units of closed end, escalonadas and ETFs will likely } \\
\text { be registered in the RNVE. SFC requires that the CIS } \\
\text { operator provide subscribers with evidence of } \\
\text { ownership of units of participation, to document a CIS } \\
\text { participant's interest. The CIS operator must also } \\
\text { maintain insurance against fraud, falsification of } \\
\text { documents and mishandling for the benefit of CIS } \\
\text { investors. The investments of the fund must be } \\
\text { accounted for, deposited and otherwise kept separate } \\
\text { from those of the operator (of whatever type: SAI, SF } \\
\text { or SCB), by law are considered to be a separate } \\
\text { patrimony than that of their manager, and are intended } \\
\text { to be bankruptcy remote, although they can be held } \\
\text { within the same entity. To the extent possible, } \\
\text { securities of each CIS fund will be held, on a fund-by- } \\
\text { fund basis, in the central depository. SFC also receives } \\
\text { daily information on the content of fund portfolios. } \\
\text { There is also a complement of rules for equitable } \\
\text { treatment of investors. The contractual portfolio format } \\
\text { for CIS does not have as robust a legal structure as } \\
\text { interests that are structured as property interests. While } \\
\text { there is substantial oversight of portfolio contents and } \\
\text { pricing by SFC, enhanced verifications of the proper } \\
\text { treatment of customer funds, particularly in cases } \\
\text { where fund operators share back offices with a group, } \\
\text { would add value to the regulatory framework. There is } \\
\text { a current project of law on CIS. }\end{array}$ \\
\hline $\begin{array}{l}\text { Principle 26. Regulation should require disclosure, as } \\
\text { set forth under the principles for issuers, which is } \\
\text { necessary to evaluate the suitability of a collective } \\
\text { investment scheme for a particular investor and the } \\
\text { value of the investor's interest in the scheme. }\end{array}$ & $\begin{array}{l}\text { All information related to the investment policies, } \\
\text { structure and risks related to CIS, including the fees } \\
\text { and charges, the rights and obligations of participants } \\
\text { and of the operators are required to be disclosed in a } \\
\text { clear way and the SFC has an oversight program for } \\
\text { the review of disclosure documents and other required } \\
\text { reports. Monthly statements of customer accounts and } \\
\text { bi-annual financial reports are required (See Principle } \\
18 \text { re: accounting). The SFC can refuse or cancel an } \\
\text { offering. It can also require a restatement of financial } \\
\text { results. }\end{array}$ \\
\hline
\end{tabular}




\begin{tabular}{|c|c|}
\hline Principle & Findings \\
\hline $\begin{array}{l}\text { Principle 27. Regulation should ensure that there is a } \\
\text { proper and disclosed basis for asset valuation and the } \\
\text { pricing and the redemption of units in a collective } \\
\text { investment scheme. }\end{array}$ & $\begin{array}{l}\text { The SFC sets forth rules for the valuation of units of } \\
\text { CIS, both for the reporting of NAV daily and for the } \\
\text { redemption of units. SFC receives the report of } \\
\text { portfolio contents and valuations daily and checks } \\
\text { these using its own methodology. Information is } \\
\text { provided monthly to investors and daily on the } \\
\text { operator's website. The SFC can require the correction } \\
\text { of pricing errors. (See also Principle } 23 \text { re price } \\
\text { providers) }\end{array}$ \\
\hline $\begin{array}{l}\text { Principle 28. Regulation should ensure that hedge funds } \\
\text { and/or hedge funds managers/advisers are subject to } \\
\text { appropriate oversight. }\end{array}$ & $\begin{array}{l}\text { SFC requires the authorization of all operators of } \\
\text { collective investments of whatever type and their } \\
\text { registry within the RNAMV. The offering designated } \\
\text { as a speculative cartera colectiva is not required } \\
\text { however to be maintained in a way that permits the } \\
\text { separate identification and treatment of the interests of } \\
\text { customers as separate from those of the operator, and } \\
100 \% \text { of the value may be loaned. There is a potential } \\
\text { for confusion about the safety of funds invested in } \\
\text { such vehicles despite the risk warnings. }\end{array}$ \\
\hline $\begin{array}{l}\text { Principle } 29 \text {. Regulation should provide for minimum } \\
\text { entry standards for market intermediaries. }\end{array}$ & $\begin{array}{l}\text { The LMV and SFC rules require an extensive } \\
\text { authorization process that includes review of the } \\
\text { background of the principals of applicants, requires } \\
\text { that senior management and certain employees be } \\
\text { certified as competent via a testing process operated by } \\
\text { the AMV, and incorporates a process for on-site visits } \\
\text { to test the operational capacity of any applicant before } \\
\text { granting authorization to act as an intermediary. }\end{array}$ \\
\hline $\begin{array}{l}\text { Principle } 30 \text {. There should be initial and ongoing capital } \\
\text { and other prudential requirements for market } \\
\text { intermediaries that reflect the risks that the } \\
\text { intermediaries undertake. }\end{array}$ & $\begin{array}{l}\text { SFC applies a simplification of the Basel model for } \\
\text { brokerage firms that clarifies that customer funds must } \\
\text { be segregated and not used for proprietary operations. } \\
\text { Significant build ups of exposure and leverage have } \\
\text { occurred within broker dealers in the past and have } \\
\text { been addressed by SFC by requiring phased wind } \\
\text { downs of positions. Continual vigilance as to the } \\
\text { quality of capital and liquidity risks within brokers is } \\
\text { warranted, including additional haircuts for repos and } \\
\text { "what if" analysis of open exposures. }\end{array}$ \\
\hline
\end{tabular}




\begin{tabular}{|c|c|}
\hline Principle & Findings \\
\hline $\begin{array}{l}\text { Principle } 31 \text {. Market intermediaries should be required } \\
\text { to establish an internal function that delivers } \\
\text { compliance with standards for internal organization and } \\
\text { operational conduct, with the aim of protecting the } \\
\text { interests of clients and their assets and ensuring proper } \\
\text { management of risk, through which management of the } \\
\text { intermediary accepts primary responsibility for these } \\
\text { matters. }\end{array}$ & $\begin{array}{l}\text { SFC has put into place a comprehensive set of } \\
\text { customer protection and operational requirements for } \\
\text { broker-dealer intermediaries. Some of these however } \\
\text { do not apply when the broker (or other type of } \\
\text { intermediary) acts as a counterparty as opposed to as } \\
\text { an intermediary with respect to debt transactions } \\
\text { (which are not comprehensively treated by IOSCO). } \\
\text { Brokers can have their own order handling systems, } \\
\text { and the AMV permits more than one system to be used } \\
\text { by an individual broker. Additional attention should be } \\
\text { paid to how orders are in practice processed and } \\
\text { transactions are submitted to the central depository to } \\
\text { assure best execution for non-professional clients and } \\
\text { proper allocations in practice in accordance with the } \\
\text { rules. This is especially true where multiple venues for } \\
\text { the same product. }\end{array}$ \\
\hline $\begin{array}{l}\text { Principle } 32 \text {. There should be procedures for dealing } \\
\text { with the failure of a market intermediary in order to } \\
\text { minimize damage and loss to investors and to contain } \\
\text { systemic risk. }\end{array}$ & $\begin{array}{l}\text { The SFC has a system of early warnings and a full } \\
\text { complement of powers to take preventive action to } \\
\text { address potential concerns with respect to the financial } \\
\text { viability of supervised entities that are broker dealers. } \\
\text { SFC has applied its powers in practice to some large } \\
\text { market participants. } \\
\text { All participants are required to have business } \\
\text { continuity plans and measures to appropriately } \\
\text { measure risk. The CCSSF has worked to upgrade } \\
\text { existing alerts and early warning systems. The SFC } \\
\text { itself, however, does not have documented procedures } \\
\text { in place to address the eventuality of a firm default. } \\
\text { (See also Principles } 1 \text { and 6) }\end{array}$ \\
\hline $\begin{array}{l}\text { Principle } 33 \text {. The establishment of trading systems } \\
\text { including securities exchanges should be subject to } \\
\text { regulatory authorization and oversight. }\end{array}$ & $\begin{array}{l}\text { Exchanges and other trading and registry systems must } \\
\text { be authorized. The rules of trading, the system, and the } \\
\text { products must be approved by SFC. The AMV also } \\
\text { certifies four categories of participants; including } \\
\text { operators and order takers. }\end{array}$ \\
\hline $\begin{array}{l}\text { Principle } 34 \text {. There should be ongoing regulatory } \\
\text { supervision of exchanges and trading systems which } \\
\text { should aim to ensure that the integrity of trading is } \\
\text { maintained through fair and equitable rules that strike } \\
\text { an appropriate balance between the demands of } \\
\text { different market participants. }\end{array}$ & $\begin{array}{l}\text { SFC conducts a full time monitoring program of the } \\
\text { BVC and the other trade negotiation and registry } \\
\text { systems, including those systems that are authorized by } \\
\text { the Central Bank. AMV also has a batch monitoring } \\
\text { system, and the entities themselves monitor trading } \\
\text { from an operational perspective. Both the SFC and the } \\
\text { AMV bring actions for misconduct and have strong } \\
\text { intervention powers. In addition there are on-site } \\
\text { inspections conducted of both AMV and SFC. } \\
\text { See also Principle } 9 \text {. }\end{array}$ \\
\hline
\end{tabular}




\begin{tabular}{|c|c|}
\hline Principle & Findings \\
\hline $\begin{array}{l}\text { Principle } 35 \text {. Regulation should promote transparency } \\
\text { of trading. }\end{array}$ & $\begin{array}{l}\text { SFC requires real-time reporting of transactions for the } \\
\text { BVC and reporting with a fifteen minute delay for } \\
\text { over-the-counter transactions. BVC prices are } \\
\text { available on the website with a } 20 \text { minute delay and } \\
\text { volume and end of day price information is available } \\
\text { as is historic pricing. All domestic equities must be } \\
\text { traded on the BVC. In that there are multiple voice } \\
\text { broking and matching systems for the same security, } \\
\text { further consolidation of pricing information would be } \\
\text { useful. See also Principle } 23 \text { re: authorized price } \\
\text { providers and information venders. }\end{array}$ \\
\hline $\begin{array}{l}\text { Principle } 36 \text {. Regulation should be designed to detect } \\
\text { and deter manipulation and other unfair trading } \\
\text { practices. }\end{array}$ & $\begin{array}{l}\text { SFC has a monitoring center, which has feeds from all } \\
\text { markets of the BVC as well as the systems of } \\
\text { negotiation and registry, and monitors activities using } \\
\text { its own proprietary tools on both a real time and an end } \\
\text { of day basis. For example, the SFC has a program to } \\
\text { review the impact of cancelled orders and market } \\
\text { tactics that could be viewed as uneconomic behavior. } \\
\text { The AMV also conducts surveillance. Manipulation } \\
\text { and misuse of privileged information are violations } \\
\text { with both administrative and criminal penalties. In the } \\
\text { latter case it is not necessary to prove the source of the } \\
\text { information. Few cases have been concluded to date, } \\
\text { but efforts to combat such abuses are being continually } \\
\text { enhanced, some cases are currently in process, and } \\
\text { AMV recently assessed fines against traders of a major } \\
\text { market participant. See also Principle } 12 \text {. }\end{array}$ \\
\hline $\begin{array}{l}\text { Principle } 37 \text {. Regulation should aim to ensure the } \\
\text { proper management of large exposures, default risk and } \\
\text { market disruption. }\end{array}$ & $\begin{array}{l}\text { SFC's monitoring system has alerts to review trading } \\
\text { activity that is out of line with pre-set tolerance levels. } \\
\text { The delay between the time trades are matched, } \\
\text { allocated and settled could permit trading intra- } \\
\text { settlement that is not properly collateralized and TTV } \\
\text { transactions, if not properly monitored, may also } \\
\text { permit double gearing risks. } \\
\text { More work on identifying and mitigating liquidity } \\
\text { risks in the securities sector is recommended. (See also } \\
\text { Principle } 30 \text { and } 32 \text {. }\end{array}$ \\
\hline $\begin{array}{l}\text { Principle } 38 \text {. Securities settlement systems and central } \\
\text { counterparties should be subject to regulatory and } \\
\text { supervisory requirements that are designed to ensure } \\
\text { that they are fair, effective and efficient and that they } \\
\text { reduce systemic risk. }\end{array}$ & See Principle 37 \\
\hline
\end{tabular}




\section{Authorities' Comments}

109. The report recognizes the progress made in regard to the supervision and regulation of the securities market, and in particular the technical capacity of SFC personnel.

110. In regard to principles 24 through 28 concerning collective investment vehicles, the document states: “(...) There is however the possibility that certain trusts may operate trusts with multiple participants that are not truly private offers, which while subject to regulation have a lesser standard than would a collective investment offering similar types of financial products."

111. As mentioned in the comments to the aide-mémoire of the August 2012 missions, the SFC does not agree with the statement to the effect that certain trusts, as investment vehicles, are subject to lesser standards than those applicable to collective investment schemes (carteras colectivas). In the evaluation of IOSCO principles, it is determined that serious confusion exists between the collective investment product and another product, the "investment trust" (fiducia de inversión) administered by trust companies (sociedades fiduciarias).

112. This class of products corresponds to a group of trust operations defined in the regulations as trust instruments whereby one person transfers possession of one or more given assets to another person, with or without transfer of title thereto, in order for the transferee to accomplish a specific purpose with them, for the benefit of either the grantor or a third party.

113. Without prejudice to the differences between individual investment trusts and the administration of collective investment schemes, it cannot be said that the former have no legal protections. In entering into any trust operation, the trust company is bound by the duties and general principles for trusts established by applicable regulations, including the duties to inform; provide reliable advice; protect the trust assets; act in fairness and good faith; and act prudently and with diligence, professionalism and expertise.

114. This group of principles is defined in the regulation, especially in the External Circular 007 of 1996, issued by the SFC.

115. In Table 6, concerning principle 28, ${ }^{15}$ the document states: “(...)The offering designated as a speculative cartera colectiva is not required however to be maintained in a way that permits the separate identification and treatment of the interests of customers as separate

\footnotetext{
${ }^{15}$ The regulations should ensure that hedge funds and/or hedge funds managers and advisors are subject to appropriate oversight.
} 
from those of the operator, and 100\% of the value may be loaned. There is a potential for confusion about the safety of funds invested in such vehicles despite the risk warnings."

116. As stated in the self-evaluation and the comments sent to the mission, all standards and regulations relating to issues such as conflicts of interest, investor protections, the principle of segregation, custody, advice and disclosure of risks, risk management, the authorization process, and the reporting of information to investors and the SFC are applicable to all types of collective investment schemes, including the speculative collective vehicles. This view is supported by numerous regulatory and supervisory provisions, especially those included in Part 3, Decree 2555 of 2010.

117. Regarding principle 19-23, principles for auditors, credit rating agencies, and other information service providers, accounting and disclosure, it is important to mention the following: The regulation for NIIF implementation in Colombia was issued on December 28th, 2012. Decree 2784 of 2012 establishes that most of the SFC's supervised entities, among other companies, must issue NIIF financial statements starting in 2015, with the following transition and enforcement deadlines:

- $\quad$ Mandatory preparation period: 2013.

- $\quad$ Transition deadline - opening statement: January 1st of 2014.

- $\quad$ Enforcement deadline (first comparative): December 31st of 2014.

- $\quad$ Reporting deadline - NIIF Financial statements -: December 31st of 2015. 


\section{Annex III. Insurance Core PrinciPles (ICPs)—Summary Assessment}

\section{INTRODUCTION AND SCOPE}

118. This report is an assessment of the insurance sector and Colombia's compliance with International Association of Insurance Supervisors' Insurance Core Principles (ICPs), as adopted in October 2011. It is based on the regulatory framework in place, the supervisory practices employed, and other conditions as they existed in June 2012.

119. Supervision of the insurance industry in Colombia is the responsibility of the Financial Superintendency of Colombia (SFC). Among the institutions subject to SFC supervision are insurers, reinsurers, savings companies, and insurance and reinsurance intermediaries. The SFC reports to the Ministry of Finance, which is in turn accountable to the President and the Congress of Colombia.

120. The assessment is based solely on the laws, regulations, and other supervisory requirements and practices that were in place in June 2012. Ongoing regulatory initiatives are noted by way of additional comments. The assessor had access to a complete self-assessment on the ICPs and responses to a detailed questionnaire that had been provided by the SFC prior to the commencement of the exercise.

121. The assessment has been informed by discussions with regulators and market participants. The assessor met with staff from SFC, various insurers, the insurance industry association, professional bodies and a rating agency. The assessor is grateful for the full cooperation extended by all. Colombia is one of the first jurisdictions to be assessed under the 2011 version of the ICPs. The efforts required by SFC to prepare the self-assessment, as well as its tremendous support during the mission, are especially appreciated.

\section{A. Executive Summary}

122. The insurance industry in Colombia is a small but rapidly growing part of the economy. In the last 5 years, gross premiums written and assets managed by the sector have more than doubled. Insurance penetration (gross premiums as a share of GDP) has increased from 2.0 percent of GDP to 2.3 percent of GDP. The industry is profitable, competitive, well capitalized, and widely held in terms of ownership. However, insurance penetration remains far below that seen in several other countries in Latin America.

123. Much of the growth in insurance has been related to the steady growth and recent stability of the economy and changes to social benefit programs in past years. The latter has helped stimulate demand for personal health and accident products, workers compensation, and annuities. Further growth appears to be reliant on increasing confidence and trust in the industry, improving growth and increasing depth of capital markets, and finding ways to increase access to insurance in underserved parts of the population. 
124. During the last five years, a number of important regulatory reforms have been introduced to improve the regulation and supervision of the insurance industry. The solvency position of the industry has been strengthened through improved solvency requirements. Requirements for risk management and internal control systems have been established on insurance companies in the areas of credit risk, market risk, operational risk and AML/CFT. Investment requirements have been improved. The technical reserve standards for earthquake insurance have been improved. Rules have been introduced relating to the market risk management of assets backing the technical reserves of general insurers. Public disclosure of financial information on insurance activity is stronger. New mortality tables for use in life insurance have been developed and introduced. Revised insolvency and liquidation procedures have been developed, and a stronger consumer protection regime has been crafted for financial services markets.

125. A number of institutional and regulatory challenges remain, however, if Colombia is to benefit from continued growth and if it is to move towards fuller compliance with international supervisory standards. Some of these challenges are within the authority of the SFC while others will require changes in laws or ministry decrees. They include the following.

126. The independence of the SFC should be strengthened, particularly with respect to the processes around the appointment, performance assessment and dismissal of the Superintendent. Establishment of a fixed term of appointment (e.g. five to seven years) should be considered in this regard.

127. Consideration should be given to the balance of authority between the Ministry of Finance and the SFC in the oversight of the insurance sector. Greater thought should be given to making decree requirements with respect to technical areas as well as the organization of responsibilities within the SFC less prescriptive and more principle based or minimum threshold based. The SFC should then be empowered to establish and manage the technical details. Better consultation with industry and more expeditious timing of regulatory changes will also aid the supervisor and industry in responding to rapidly changing markets.

128. Licensing, changes in control, portfolio transfers and suitability requirements are generally in line with international standards; however, a clear definition of insurance business in the law may assist the SFC in dealing with issues related to "near insurance" products. The licensing requirements are clearly stated and cover both financial as well as nonfinancial aspects to warrant sound operations. It the past, however, there have been some issues associated whether some products are insurance or not (e.g. funeral service related products). A clear definition of insurance business in the law may assist the SFC in dealing with such issues.

129. Many of the regulatory requirements with respect to solvency and internal controls are relatively new. It will take time to fine tune and further develop these requirements. Additional changes to technical reserve requirements and the solvency regime are also necessary 
to address the full range of risks that insurers face. The SFC and the MoF are aware of the pressing need for these changes. It is important that they be introduced in a timely manner and in full consultation with the regulated industry.

130. The SFC should be commended for the steps it has taken in developing a risk based supervisory framework for insurers, but much work remains to ensure that this approach to supervision is effective. A risk based approach to supervision requires not only changes to the policies and procedures of the organization, but to the basic supervisory culture. Care needs to be taken to ensure that the new framework is properly documented, that staff are well trained and competent, that they communicate with each other and are properly focused in the execution of their duties. Some reorganization of the supervisory departments to focus on the entity being regulated rather than risk categories should be considered to help ensure this takes place. Increased legal protection for staff exercising their authority in good faith may also aid in implementation of the framework and other supervisory responsibilities.

\section{Governance and enterprise risk management for solvency purposes need to be} further developed. Enterprise risk management is an evolving field, both in Colombia and internationally. Some Colombian insurers have sophisticated enterprise risk management systems, while others are at early stages of development. Consideration should be given to developing a stronger enterprise risk management cultures within organizations starting with the boards of institutions. This may require additional governance requirements (e.g. mandatory establishment of risk management committees, asset liability management policies, risk tolerance statements); it may also require development and promulgation of best practices suited to small and medium sized institutions. The industry association should be encouraged to play a role in this work.

\section{Continued development of capital markets and creation of long term investment} products is critical to the continued development of the life insurance industry. At present, it is very difficult for the industry to match the long term liability associated with annuity products (or other long term products) with assets of similar duration. Unless ways can be found to address this issue, insurers will be unwilling or unable to provide such products because of the asset liability matching risks associated with them. Furthermore, increased certainty needs to be established around pension annuities. At present, many private pension annuities are linked to minimum wage increases. An increase in the minimum wage results in an increase in the benefits that insures must pay to beneficiaries of most annuity contracts in place. Given that insurers cannot predict the rate of minimum wage increase they cannot properly price pension annuity products. As the private pension system depends on the availability of affordable annuities, the future stability and feasibility of private pension programs depends on a solution to this issue.

\section{Colombia has signaled its intention to move towards adoption of International} Financial Reporting Standards and international auditing standards. The insurance industry is expected to begin adoption of these practices in 2014 or 2015. It is not clear, however, that all insurers are prepared to begin this transition. SFC survey information suggests that many are not. 
Other difficult regulatory changes such as the changes to reserving requirements are also contemplated for the same time frames. Care will need to be taken to ensure that all of these initiatives are completed in a coordinated fashion that leads to real improvement in asset and liability valuation and reserving processes.

134. Continued development of the insurance industry is dependent on the availability of actuarial skills and the development of an actuarial profession. Actuaries play an important role in insurer risk management and control and in developing more sophisticated products. Actuarial capacity in Colombia is low (perhaps less than 120 people). Establishment of fuller actuarial programs at local universities may be a start towards addressing this problem. In addition, a plan should be developed towards establishing a self regulating actuarial profession charged with establishment of actuarial standards and licensing and disciplining its members. A proposal from actuarial associations and the universities has been developed by the actuaries associations and industry. Timely consideration of this proposal is warranted.

\section{Consumer protection has made important progress in the last three years, but}

more work is needed. The establishment of comprehensive consumer protection systems as described in Law 1328 of 2009 is a major step forward. Further improvements can be made by improving oversight of the activities of insurance agents. Consideration should be given to establishing a basic public registration system for insurance agents, including basic suitability requirements, and minimum educational standards, and a code of conduct and training. The system should include a public database on those agents who have been formally disciplined for actions in the conduct of insurance business or disqualified from registration. At present, consumers have few options to check the suitability and character of agents selling insurance to them and a large portion of consumer complaints relate directly to the actions of agents. Insurers also have difficulty checking the background and suitability of prospective agents and would benefit from such a system. An industry based self regulating organization, overseen by SFC, may provide a model that benefits both industry and consumers.

\section{The regulatory framework for group supervision needs improvement. The} Colombian market is dominated by insurers belonging to large financial groups. The supervision of large conglomerates, however, does not extend to all relevant entities in the group. The Superintendent's authority over financial holding companies or industrial members of a conglomerate is extremely limited, impacting the SFC's authority to require that consolidated financial reporting and consolidated risk management take place.

\section{B. Institutional Overview}

\section{Under the Colombian Constitution, the President of Colombia exercises the} authority to inspect, monitor and control financial activities through the Superintendencia Financiera de Colombia (SFC). The SFC was established by Presidential decree 4327 of 2005. The decree merged the banking and insurance regulator (Superintendencia Bancaria) with the supervisory authority for securities markets (Superintendencia de Valores). The SFC is 
established as a technical body under the Ministry of Finance, with legal, administrative and financial autonomy. The organization has approximately790 staff and is largely funded from fees set by the Superintendent on regulated entities. The fees for insurers are paid twice per year and are based on a rate applied to institutional assets. The Superintendent also has authority to make additional assessments in the event of funding shortfalls.

138. The SFC in an integrated financial services supervisory authority. Its activities extend to insurance, banking, securities, pensions, endowments and trusts. In regard to insurance, under the office of the Superintendent there are two key Supervisory divisions: Institutional Supervision and Supervision of the Risks and Market Conduct. The latter department is primarily responsible for the supervision of risks in all financial institutions under the SFC's supervisory framework and has branches responsible for credit, market, operational risk as well as money laundering, financial conglomerates and institutional governance.

139. The Institutional Supervision department is primarily responsible for licensing and regulatory approvals and verifications and is organized by particular area of financial services (e.g. pensions, insurance, securities brokers and agents). The insurance section is responsible for insurance, reinsurance, and insurance and reinsurance brokers. Its mandate includes: insurer licensing, reinsurer registration, insurance broker licensing, authorization of classes, policies and maximum rates of insurance, review and monitoring of actuarial calculations, technical reserves and capital requirements. There are 60 staff dedicated solely to insurance in this section. Other areas of the organization impacting on insurance include the risk supervision areas (which have 216 staff) and the research and development area which has 49 staff.

140. The SFC has a Department of Financial Consumer Protection which provides information and advice on market conduct and financial literacy issues across the financial services sector. This office reports directly to the Superintendent and has a staff of 15 . In addition, Colombia has recently established the Judicial Power Department which is a judicial body established to hear financial consumer cases. It was established as an alternative to the court system or commercial arbitration and has only recently begun operations.

141. The SFC also has a five member Advisory Council comprised of experts with backgrounds in economics, finance, securities markets or general legislation. Council members are appointed and removed by the President of the Republic and provide advice in areas like the strategic plan of the SFC, its operational framework, management policies of the organization, and major regulatory decisions such as those involving licensing, amalgamation or wind-up of a financial institution.

142. The Federacion de Aseguradores Colombianos (Fasecolda) is a non-profit industry association that represents 24 out of 25 non-life insurers and approximately 18 out of 19 life insurers. The association is headed by a former Minister of Finance and funded by industry contributions. It is governed by a Board of Directors comprised of Chief Executives from 
member companies. It has several technical sub-committees that provide services to members along major lines of business.

143. Colombia also has an insurance brokers association (Asociacion Colombiana de Corredores de Seguros - ACOAS) which represents insurance brokers operating in the country. It currently has eight members.

\section{Market Overview}

144. Colombia is currently Latin America's fourth largest economy and its sixth largest insurance market. The insurance sector is a small component of the country's economy as total industry premiums were only 2.3 percent of GDP and total assets were 5.5 percent of GDP. The average Colombian spends approximately $\$ 140$ dollars per year on insurance. Relative to its neighbors, Colombia ranks below Chile, Venezuela, Panama, Brazil, Argentina and Ecuador in terms of market penetration (the ratio of insurance premiums to GDP). The sector is, however, growing rapidly. Gross premiums written were approximately COP 6,520 bn. in 2005 and increased to COP 14,162 bn. in 2011, at an average annual rate, of approximately 13.8 percent. This significantly exceeded the nominal GDP growth rate of approximately 9 percent for the same time period. As a result, the insurance penetration ratio has increased from 1.91 percent to its current level. Significant potential for further growth appears to be possible given the low levels of penetration.

145. Non-life insurance comprises the largest portion of the insurance market accounting for approximately 49 percent of gross premiums written in 2011 excluding Personal Accident and Healthcare. From 2005 to 2011, non-life premiums grew at an average annual rate of approximately 11.5 percent. Motor insurance accounted for approximately 44 percent of total non-life premiums. Property insurance accounted for a further 23 percent, surety, for 9 percent and construction and engineering insurance, at 7 percent, accounted for much of the remainder.

146. Life insurance accounted for approximately 43 percent of gross premiums written in 2011 excluding Personal Accident and Healthcare. Life insurance premiums have been growing at an average annual rate of approximately 12.5 percent since 2005 . Group life, workers compensation and disability insurance account for almost 74 percent of the life total. Workers compensation and group life have been the fastest growing areas of the life sector over the last five years. Pensions and annuities growth has also been strong except in 2010. Government policy decisions with respect to pensions, health care and workers compensation have helped spur growth rates in private insurance markets in these areas. Workers compensation insurance is purchased by employers from private insurers. Annuities and voluntary pensions have expanded due to changes in the state pension system and changes in the healthcare system have increased interest in voluntary health insurance and group benefit programs.

147. Personal Accident and Healthcare Insurance comprised approximately nine percent of premiums written or COP 1206 bn. Roughly 44 percent of this total is personal 
accident insurance and 56 percent is healthcare insurance. Both non-life and life insurers can write this business but the larger portion is written by life insurance companies.

148. On average, the non-life industry has retained between $69-74$ percent of gross premiums written over the last five years, although this varies considerably depending on the line of business. There is no minimal risk retention limit in Colombia though there is a maximum retention for an insurer - any one risk insured cannot be more than $10 \%$ of the company's equity. Property is the largest reinsurance class and treaty reinsurance is typically sought for both single risk and catastrophic exposure. Earthquake is the largest catastrophic exposure. Quota share treaties are used in surety lines. Facultative reinsurance arrangements are used in areas like marine hull, aviation, and terrorism. In the life insurance market approximately 94 percent of gross premiums written were retained in 2010. Smaller life insurers in Colombia tend to place reinsurance on a quota share basis backed by excess of loss while larger life insurers have only excess of loss coverage.

149. The Colombian market has a number of compulsory insurance products. These products are listed below:

150. The insurance market is comprised of 25 non-life insurers (including two cooperatives), and 19 life insurers. Insurers must be either life or non- life insurers and can be either joint stock companies or cooperatives/mutuals. Insurers may be formed as local companies, foreign owned subsidiaries, or foreign branch operations. Colombia's reinsurers are all foreign companies some of which operate through local offices while others are accessed through brokers. There are two state owned insurers: La Previsoria, a non-life insurer and Positiva, a life insurer. In 2011, La Previsora was a significant participant in the non-life market accounting for 6.9 percent of non-life premiums. Positiva, underwrites individual life business and workers compensation business. It assumed the assets, liabilities and workers compensation (professional risks) contracts of the Social Insurance Institute (Instituto de Seguros Sociales-ISS) in 2008.

151. Table 3 lists the ten major non-life and life insurers in terms of premiums written in 2011. The five largest non-life insurers account for approximately 48 percent of premiums written while the ten largest insurers account for 77 percent of premiums written. The non-life industry has a Herfindal-Hirschman index of approximately 727 indicating an un-concentrated market. In the life sector (including personal accident and sickness premiums) the five largest insurers account for 67 percent of total assets while the largest ten account for approximately 91 percent of total assets. The life industry has a Herfindal-Hirschman index of approximately 1123 , indicating moderate concentration. The levels of concentration for both life and non-life have not increased significantly over the last five years.

152. Colombian financial conglomerates and internationally active insurance groups play a very important role in the market. Insurers associated with Colombian financial 
conglomerates account for more than 36 percent of gross premiums written while approximately 40 percent of gross premiums written are by companies that are ultimately foreign controlled.

153. Both the life insurance industry and the non-life insurance industry have been profitable over the last five years and the capital position of the industry is improving as insurers have been required to meet stronger minimum solvency requirements. Net earnings in 2011 have declined from 2010 levels but much of the decline appears to be due to declining investment earnings and the introduction of new measures to strengthen solvency requirements of the industry. These changes have resulted in assets and equity growing faster than premiums over the last five years. The ROE has decreased from previous years largely due to declining investment returns in 2011.

154. Asset growth in the life insurance industry between 2007 and 2008 largely reflects the transfer of assets, liabilities and contracts for workers compensation insurance (professionals risk business) from the state run Social Insurance Institute (Instituto de Seguros Sociales-ISS) to Previsora Vida in accordance with the Resolution 1293 of August 11, 2008. This resolution was part of a number of broad social benefits reforms undertaken by the government. In October 8, 2008 the insurer changed its name to Positiva Compania de Seguros .

155. Investments in the insurance sector appear to be conservative and short term, primarily comprising fixed income instruments. Approximately 51 percent of investments are government securities, 29 percent are corporate securities (mainly fixed term deposits), and 12 percent are equities. All other types of investment comprise less than 8 percent of the total. Treasury decree 2953 of 2010 updated the investment regulations applying to technical reserves.

156. Insurance products are distributed primarily through traditional agent and broker networks. Agents account for perhaps 60 percent of the business. Agents are not supervised by the SFC. Insurers are responsible for the actions of the agents that represent them. While there are no official statistics on agents, industry sources suggest there are more than 10,000 agents in the country. Most of their work tends to be in personal lines. Agents are also allowed to represent more than one insurer. Some insurers also have in-house agent sales staff who are remunerated through a combination of salary and commissions. With the exception of Bancassurance, non-traditional distribution methods (e.g. internet sales, telemarketing) comprise a small share of the market. A 2009 study by the insurance industry association indicates that Bancassurance is responsible for distribution of approximately 20 percent of life insurance products. Approximately 81 percent of these sales were for group life (including creditor group life) and personal accident insurance products.

157. There are approximately 50 insurance brokerages in Colombia: 34 insurance brokers and 14 reinsurance brokers. These are regulated by the SFC. Insurance Brokers tend to specialize in commercial or industrial clients. For example, in the life insurance sector life agents tend to dominate individual life sales while brokers control group product sales. Agents 
and Brokers are largely remunerated through commission income. Commissions tend to range between 5-20 percent depending on the type of insurance for non-life business. Life insurance commissions, other than group insurance and workers compensation, can be considerably higher. First year premiums for renewable term and universal life insurance can range from 35 to 40 percent with commissions in the 25 percent range in subsequent years. Commissions on health care insurance range up to 25 percent. Brokers tend to garner slightly higher percentage commissions than agents.

\section{Preconditions for Effective Insurance Supervision}

158. Colombia's economic policies have supported increasing stability and strong economic growth in recent years. Real GDP grew by 5.9 percent in 2011 and inflation ended 2011 at 3.7 percent, continuing almost a decade of strong economic performance. The growth was largely driven by both domestic demand and the strength of the mining and energy sectors. The country has one of Latin America's highest unemployment rates, however, and faces problems with physical infrastructure and catastrophic risks (e.g., earthquakes and more recently with major floods).

159. Colombia has an established civil law system. It includes a constitution, civil and criminal codes, congressional legislation, presidential decrees and ministerial regulations. The general faculties and powers set out in Congressional laws are further developed and defined by decrees and regulations and by SFC circulars. Colombia has a Commercial Code which acts as the basic business law for the country, a corporate regimen (law 222 of 1995) and an insolvency regime (Law 1116 of 2006). There is a bifurcated judicial system, one system for private law (civil and criminal matters) headed by the Supreme Court, and one for public law (administrative law) which is the responsibility of the Council of State. The Supreme Court is comprised of 23 judges who are appointed by Congress for a period of eight years. In addition, there is a Constitutional Court, which is charged with protecting the integrity and supremacy of the Constitution.

160. The court system is active and the number of cases is growing but the legal process can be costly and lengthy. Most civil claims for loss injury or damage must be initiated within two years of the event occurring. In June 2011, however, the World Bank estimated that the length of time from the point when a plaintiff launches an action to enforce a contract until payment of a claim can take more than three years.

161. Colombia has an established financial reporting framework and is moving towards IFRS. Under the Colombian Constitution, Congress has the authority to issue generally accepted accounting principles (GAAP). Congress can delegate this authority to the executive branch and other institutions through an act of law. Law 43 of 1990 created the Technical Council for Public Accounting (Consejo) to issue technical guidance on accounting standards. Consejo developed a set of accounting principles that they termed Colombian GAAP. In 1993, the President Colombia issued Decree 2649 which established Colombian GAAP as the accounting standards 
for all enterprises in the country. Subsequently under Law 222 of 1995, However, by Law 45 of 1993 and Decree 663 of 1993, the SFC can issue accounting standards related to their supervisory duties.

162. Colombian GAAP was developed by Consejo in early 1990s on the basis of U.S. GAAP and International Accounting Standards. Colombian GAAP is not, however, fully compliant with the U.S. GAAP or international standards. With regard to audit, Colombia relies on statutory auditors whose appointment, in the case of financial institutions, must be approved by the SFC. Insurers are required to have a statutory auditor conduct an annual audit of the finances of their organization. The auditors must be certified public accountants and must ensure and attest to the accuracy of the published accounting information. Audits must be conducted in accordance with Colombian audit standards.

163. In July, 2009, the Congress enacted Law 1314 which states the government's intention to converge Colombian GAAP with international standards. In June, 2011, Consejo submitted an official proposal to the Colombian Minister of Finance and Commerce regarding the adoption of international accounting and auditing standards and in December of 2011 the President decreed that large and medium sized enterprises can voluntarily implement IFRS starting in 2012. The SFC recently published a timetable for the implementation of IFRS. .

164. Colombia has a small actuarial community and there are concerns about the number of actuaries available to support the insurance sector. There are perhaps 120 trained actuaries currently working in the country. They do not currently have professional standing and a signing actuary is not required to be a member of an actuarial association. The country's two actuarial associations do not have the ability to self regulate actuaries; however, they do have minimum education requirements as part of their general membership requirements.

165. The integrity of the financial system is supported by the Coordinating Committee of the Financial System (CCSSF). This is a high level committee comprised of the Minister of Finance, the Chair of the Central Bank, the Superintendent of the Financial Superintendency of Colombia and the Director of the Guarantee Fund for Financial Institutions (FOGAFIN). The committee meets at least four times per year with the mandate of strengthening financial stability. It serves as a vehicle for coordinated decision making and has a medium term agenda that includes the development of an early warning system for systemic issues, issue resolution mechanisms and an interagency information sharing protocol.

166. The financial and capital markets have experienced significant growth since the last FSAP assessment but still lack depth and long term instruments. The availability of long-term fixed-income investments to support the long duration insurance products is limited. This is important because the growth of the life insurance sector and the payout phase of Colombia's pension system depends on the availability of such instruments. 


\section{E. Main Findings}

\section{General:}

167. Significant progress has been made over the last five years. The SFC is a wellresourced professional organization with a clear strategic direction in the insurance area. There have been significant improvements in regulatory and supervisory practices and more changes are planned. Significant challenges remain, however, if insurance supervision is to move towards fuller compliance with international standards and if it is to continue to build confidence in the growing insurance sector.

\section{Supervisory Objectives and Independence:}

168. The independence of the SFC should be strengthened by strengthening processes around the appointment, performance assessment and dismissal of the Superintendent. Establishment of a fixed term of appointment (e.g. five to seven years) should be considered in this regard. At present, there are no explicit procedures regarding the appointment, performance evaluation and dismissal of the Superintendent and there has been frequent turnover in the position in recent years (e.g. the average term of the last three superintendents has been less than three years). The Superintendent is appointed and can be removed the President without disclosure of the reasons. The Superintendent may also be censured and removed by Congress.

169. Greater thought should be given to making decree requirements dealing with technical areas, and organization of responsibilities within the SFC, less prescriptive and more principle based. This may empower the SFC to manage rapidly changing financial markets better and establish appropriate technical details. Better consultation with industry and more expeditious timing of regulatory changes will aid the supervisor and industry in responding to rapidly changing markets.

170. Improved protection for staff from lawsuits for actions taken in good faith should be given a high priority and implemented as soon as possible. Strong protection is necessary if the SFC is to move toward a risk based supervisory approach that requires the exercise of greater judgment than compliance oriented supervisory frameworks.

\section{Licensing, Suitability and Control:}

171. Licensing, suitability and control processes while strong in many respects would benefit from a clear definition of insurance business in the law. This may help address licensing issues related to "near insurance products" (eg. funeral insurance, prepaid medical). The licensing regime might also benefit from the ability to attach conditions to licenses as a way of increasing market participation without endangering the protection of consumers. These issues are likely to become more important as the market grows and as insurers seek to develop more inclusive insurance products like microinsurance products. 


\section{Governance and Control:}

172. Board training, explicit minimum competency requirements for directors and the development of guidance on best practices with respect to board governance and enterprise risk management should be considered as means of improving the functioning of boards. Fine tuning of internal controls and the development of an actuarial control function and greater actuarial capacity within institutions is also necessary if insurers are to move towards better enterprise risk management and the development of more complex insurance products.

\section{Supervisory Process:}

173. The SFC has taken very significant steps towards developing and implementing an improved risk based supervisory framework. Much work remains to be completed to ensure that supervision is carried out in a risk based and cost effective manner. A risk based approach to supervision requires not only changes to the policies and procedures of the organization, but to the basic supervisory culture. Care need to be taken to ensure that the new framework is properly documented, that adequate guidance and training are provided, that it is implemented in a consistent manner, and that the framework does not result in unreasonable and unnecessary regulatory burden on the supervised entities. Some reorganization of the supervisory departments to focus on the entity being regulated rather than risk category may aid in framework implementation.

\section{Prudential Standards:}

174. Changes in the solvency requirements, internal control requirements, and the introduction of new mortality tables for life business and the introduction of new investment regulations in recent years have helped to improve prudential practices and the measurement of solvency position in the industry. Further changes, related to reserving practices and solvency requirements, are necessary to move towards international solvency standards. The SFC is aware of these issues and is moving to address them.

175. In addition, policy holders with outstanding claims need to be given a clear priority in law in the event of a liquidation. ICP 12.1 requires that a high legal priority be established for the protection of the rights and entitlements of policy holders in such circumstances.

\section{Group Supervision and Cross Border Cooperation and Management:}

176. The regulatory framework for group supervision needs improvement. The Colombian market is dominated by insurers belonging to large financial groups. The supervision of large conglomerates, however, does not extend to all relevant entities in the group. The Superintendent's authority over financial holding companies or industrial members of a 
conglomerate is extremely limited, impacting the SFC's authority to ensure consolidated financial reporting and consolidated risk management are taking place.

177. Weaknesses in group supervision can also increase problems with cross border crisis management. Cross-border cooperation and coordination specifically related to crisis management of Colombian insurers is progressing but many of the details of a crisis management system have yet to be completed. The SFC is working hard with other supervisors to complete its work in this area but much remains to be done.

\section{Market Conduct:}

178. Consumer protection has made important progress in the last years, but more work is needed. The establishment of the consumer protection system is a significant step forward. The requirement for an effective ombudsman in each insurer has proven to be a successful measure to protect consumers. Care is needed to ensure that the new system is adequately resourced and cost effective. Further fine tuning of policies and procedures will likely be required as the SFC gains more experience with the new requirements especially with respect to inclusive insurance products like micro insurance.

\section{Better oversight of insurance agents is necessary to reduce the number of}

complaints and ensure that customers are treated fairly. Some of these requirements should include a basic licensing/registration system for insurance agents, a code of conduct, basic suitability requirements and minimum educational standards, and the establishment of a public database on those agents who have been formally disciplined for actions in the conduct of insurance business or disqualified from registration. Establishment of a self-regulatory organization for agents, with appropriate SFC oversight, should be considered as a potential delivery vehicle. 
Table 7. Colombia-Summary of Observance of the Insurance Core Principles

\begin{tabular}{|c|c|}
\hline $\begin{array}{c}\text { Insurance Core } \\
\text { Principle }\end{array}$ & Overall Comments \\
\hline $\begin{array}{ll}\text { - } & \text { Objectives, } \\
\text { Powers and } \\
\text { Responsibilities of } \\
\text { the Supervisor }\end{array}$ & $\begin{array}{l}\text { The SFC is clearly defined as the authority responsible for } \\
\text { supervision of insurance. The objectives of supervision are } \\
\text { defined and include protection of the interests of policyholders } \\
\text { and maintenance of a stable and fair insurance sector. } \\
\text { The Superintendent has the ability to initiate regulatory } \\
\text { changes but regulatory changes can take considerable time to } \\
\text { develop and implement. Care should be taken to ensure that } \\
\text { regulatory changes are instituted in a timely manner and all } \\
\text { affected parties are appropriately consulted. }\end{array}$ \\
\hline 2 - Supervisor & $\begin{array}{l}\text { The SFCs operational independence should be strengthened } \\
\text { by strengthening requirements around the appointment of the } \\
\text { Superintendent. Nomination and appointment of the } \\
\text { Superintendent does not have a framework and few minimal } \\
\text { requirements for the appointment exist. The Superintendent } \\
\text { can at any time be dismissed by the President of the Republic } \\
\text { or Congress. Dismissal reasons are not published. } \\
\text { In addition, consideration should be given to the balance of } \\
\text { authority between the Ministry and the SFC in the oversight of } \\
\text { the insurance sector. Greater thought should be given to } \\
\text { making decree requirements with respect to technical areas } \\
\text { less prescriptive and more principle based, or minimum } \\
\text { threshold based, and to empowering the SFC to establish and } \\
\text { manage the technical details. } \\
\text { Improved protection for staff from lawsuits for actions taken in } \\
\text { good faith should be given a high priority and implemented as } \\
\text { soon as possible. Strong protection is necessary if staff are to } \\
\text { move toward a risk based supervisory approach that requires } \\
\text { the exercise of greater judgment than compliance oriented } \\
\text { supervisory frameworks. }\end{array}$ \\
\hline $\begin{array}{ll}3 \text { - } & \text { Information } \\
& \text { Exchange and } \\
\text { Confidentiality } \\
\text { Requirements }\end{array}$ & $\begin{array}{l}\text { SFC has memoranda of understanding in place with several } \\
\text { domestic and international supervisory agencies. SFC also } \\
\text { has the ability to share information on an ad hoc basis } \\
\text { provided the other party can protect its confidentiality. The } \\
\text { SFC has not, however, signed the IAIS Multilateral } \\
\text { Memorandum of Understanding on information sharing which } \\
\text { would permit timely information sharing with more insurance } \\
\text { supervisory parties. }\end{array}$ \\
\hline
\end{tabular}




\begin{tabular}{|c|c|}
\hline $\begin{array}{c}\text { Insurance Core } \\
\text { Principle }\end{array}$ & Overall Comments \\
\hline 4 - $\quad$ Licensing & $\begin{array}{l}\text { Licensing requirements to engage in insurance activities are } \\
\text { set in the insurance law and unlicensed operations can be } \\
\text { severely sanctioned. The licensing requirements are clearly } \\
\text { stated and cover both financial as well as non financial } \\
\text { aspects to warrant sound operations. } \\
\text { A clear definition of insurance business in the law would help } \\
\text { the SFC to deal with licensing issues related to "near } \\
\text { insurance products" (eg. funeral insurance, prepaid medical). } \\
\text { The licensing regime might also benefit from the ability to } \\
\text { attach conditions to licenses as a way of increasing market } \\
\text { participation without endangering the protection of consumers. }\end{array}$ \\
\hline $\begin{array}{ll}5- & \text { Suitability of } \\
& \text { Persons }\end{array}$ & $\begin{array}{l}\text { The SFC administers requirements for the solvency and } \\
\text { character of officers, statutory position holders and major } \\
\text { shareholders of insurers. Establishment of minimum } \\
\text { competency requirements for officers and directors may be of } \\
\text { additional value. }\end{array}$ \\
\hline $\begin{array}{ll}6- & \text { Changes in } \\
& \text { Control and } \\
& \text { Portfolio Transfers }\end{array}$ & $\begin{array}{l}\text { Changes in control and portfolio transfers require written } \\
\text { approval by the SFC. There are clear rules and expectations } \\
\text { set up by the requirements. }\end{array}$ \\
\hline $\begin{array}{ll}7- & \text { Corporate } \\
& \text { Governance }\end{array}$ & $\begin{array}{l}\text { Director competency and board training are reported to be a } \\
\text { concern, particularly in small institutions. Board training, } \\
\text { explicit minimum competency requirements and development } \\
\text { of best practices with respect to board governance and } \\
\text { enterprise risk management should be considered as a means } \\
\text { of improving the functioning of boards. }\end{array}$ \\
\hline $\begin{array}{l}\text { Risk Management } \\
\text { and Internal } \\
\text { Controls }\end{array}$ & $\begin{array}{l}\text { In recent years, SFC has taken steps to emphasize the } \\
\text { importance of risk management and internal controls and to } \\
\text { establish effective internal control frameworks. } \\
\text { The absence of a functioning actuarial profession impedes the } \\
\text { ability and effectiveness of insurers in controlling insurance } \\
\text { risk. This will likely become an increasingly important limitation } \\
\text { as the industry grows and becomes more complicated. This is } \\
\text { particularly true with respect to life insurance. }\end{array}$ \\
\hline $\begin{array}{ll}\text { - } & \text { Supervisory } \\
& \text { Review and } \\
& \text { Reporting }\end{array}$ & $\begin{array}{l}\text { While the SFC is to be commended for the steps it has taken } \\
\text { in developing and refining the supervisory framework so far, } \\
\text { much work remains to be completed to ensure that } \\
\text { supervision is carried out in a truly risk based and cost } \\
\text { effective manner. } \\
\text { A risk based approach to supervision requires not only } \\
\text { changes to the policies and procedures of the organization, }\end{array}$ \\
\hline
\end{tabular}




\begin{tabular}{|c|c|}
\hline Insurance Core & Overall Comments \\
\hline & $\begin{array}{l}\text { but to the basic supervisory culture. Care needs to be taken to } \\
\text { ensure that the new framework is implemented in a consistent } \\
\text { manner, that the actions of staff are truly risk based and } \\
\text { effective and that the framework does not result in } \\
\text { unreasonable and unnecessary regulatory burden on the } \\
\text { supervised entities. }\end{array}$ \\
\hline $\begin{array}{l}10 \text { - } \text { Preventive and } \\
\text { Corrective } \\
\text { Measures }\end{array}$ & $\begin{array}{l}\text { The supervisor has sufficient powers to take preventive and } \\
\text { corrective actions on a timely basis to protect the } \\
\text { policyholders and the SFC uses these powers extensively. }\end{array}$ \\
\hline 11 - Enforcement & $\begin{array}{l}\text { SFC has the powers to enforce the measures imposed on } \\
\text { supervised entities and the process of appeals guarantees } \\
\text { similar treatment for similar actions. Better protection from } \\
\text { legal action for SFC staff in the good faith execution of their } \\
\text { duties should be established. }\end{array}$ \\
\hline $\begin{array}{l}\text { 12- Winding-up and } \\
\text { Exit from the } \\
\text { Market }\end{array}$ & $\begin{array}{l}\text { The capital level at which an insurer must be passed to } \\
\text { FOGAFIN for liquidation appears old and arbitrary. In addition, } \\
\text { not all policyholders with insurance claims appear to have } \\
\text { special priority in the event of a forced liquidation. }\end{array}$ \\
\hline $\begin{array}{ll}13 \text { - } & \text { Reinsurance and } \\
\text { Other Forms of } \\
\text { Risk Transfer }\end{array}$ & $\begin{array}{l}\text { Reinsurance requirements appear to be appropriate for the } \\
\text { size and nature of the market. }\end{array}$ \\
\hline 14 - Valuation & $\begin{array}{l}\text { The methods used for the valuation of assets and liabilities } \\
\text { are transparent but on the liability side they do not cover } \\
\text { important risks that insures are exposed to. } \\
\text { The proposed reserving decree and the transition to IFRS are } \\
\text { significant opportunities to update and improve reserving } \\
\text { practices and the system of asset and liability valuation and to } \\
\text { build fuller compliance with the requirements of the core } \\
\text { principle. }\end{array}$ \\
\hline 15 - Investment & $\begin{array}{l}\text { The investment requirements are transparent and their } \\
\text { objectives include diversification, safety, profitability, solvency, } \\
\text { and liquidity. The industry does not seem to be hindered by } \\
\text { the existing investment limitations to execute appropriate } \\
\text { investment strategies, with the exception of the lack of long } \\
\text { term assets to match long term liabilities for existing in annuity } \\
\text { products. }\end{array}$ \\
\hline $\begin{array}{ll}16- & \text { Enterprise Risk } \\
& \text { Management for } \\
\text { Solvency }\end{array}$ & $\begin{array}{l}\text { Enterprise risk management is an evolving field, both in } \\
\text { Colombia and internationally. Some Colombian insurers have } \\
\text { enterprise risk management systems, while others are at }\end{array}$ \\
\hline
\end{tabular}




\begin{tabular}{|c|c|}
\hline $\begin{array}{c}\text { Insurance Core } \\
\text { Principle }\end{array}$ & Overall Comments \\
\hline Purposes & $\begin{array}{l}\text { earlier stages of development. } \\
\text { SFC should establish more comprehensive enterprise risk } \\
\text { management requirements that ensure insurers address all } \\
\text { relevant and material risks, consistent with the standards } \\
\text { under ICP 16. The SFC should also actively supervise the } \\
\text { efforts of insurers in this area, to help ensure that their } \\
\text { capabilities are evolving at an appropriate pace. This } \\
\text { requirement will likely take time to implement and will depend } \\
\text { on the development of other components of the regulatory } \\
\text { framework and the insurance sector. }\end{array}$ \\
\hline 17 - Capital Adequacy & $\begin{array}{l}\text { Colombia has recently incorporated more risk specific capital } \\
\text { requirements into its solvency regime. This is a positive step } \\
\text { towards modernization but further development, particularly } \\
\text { for operational risk is necessary. } \\
\text { All capital requirements are at the legal entity level, to } \\
\text { enhance supervision, the introduction of capital requirements } \\
\text { at the group level should also be considered. }\end{array}$ \\
\hline 18 - Intermediaries & $\begin{array}{l}\text { As effective regulation of intermediaries is extremely important } \\
\text { to building and maintaining consumer confidence in the } \\
\text { insurance industry, establishing better and more uniform } \\
\text { requirements for the insurance intermediaries is a necessary } \\
\text { priority. }\end{array}$ \\
\hline $\begin{array}{ll}19- & \text { Conduct of } \\
\text { Business }\end{array}$ & $\begin{array}{l}\text { While law1328 of } 2009 \text { significantly improves the consumer } \\
\text { protection system, better oversight of insurance agents is } \\
\text { necessary to reduce complaints and ensure that customers } \\
\text { are treated fairly (see ICP 18). In addition, further fine tuning } \\
\text { of policies and procedures additional resources will likely be } \\
\text { required as the SFC gains more experience with the new } \\
\text { requirements. } \\
\text { The insurance market is currently incorporating a large } \\
\text { number of first time consumers. There is a need to ensure that } \\
\text { inclusive insurance products like micro insurance are } \\
\text { appropriately regulated. }\end{array}$ \\
\hline 20 - Public Disclosure & $\begin{array}{l}\text { As the supervisory framework becomes more risk based and } \\
\text { as enterprise risk management improves in institutions, } \\
\text { greater information on institutional risk, governance and ERM } \\
\text { should be required. }\end{array}$ \\
\hline $\begin{array}{l}21 \text { - Countering Fraud } \\
\text { in Insurance }\end{array}$ & $\begin{array}{l}\text { The SFC has taken an active role in the formalization of the } \\
\text { requirements on internal controls to deter, prevent, detect, } \\
\text { report and remedy fraud in insurance. } \\
\text { Development of a joint SFC/industry fraud strategy would }\end{array}$ \\
\hline
\end{tabular}




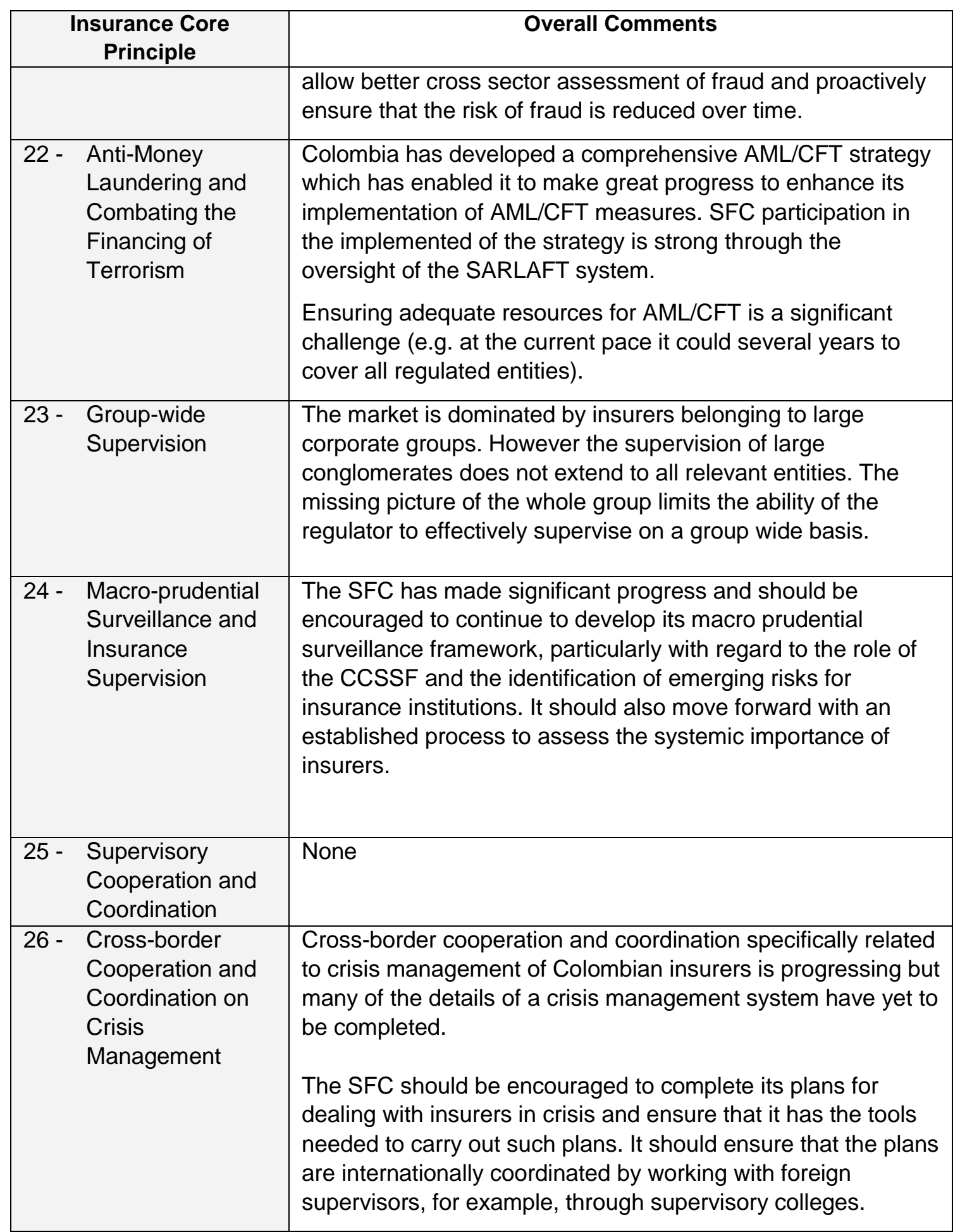




\section{Table 8. Colombia—Recommendations to Improve Observance of ICPs}

\begin{tabular}{|c|c|}
\hline Insurance Core Principle & Recommendations \\
\hline $\begin{array}{l}1 \text { - Objectives, Powers and } \\
\text { Responsibilities of the Supervisor }\end{array}$ & $\begin{array}{l}\text { Care should be taken to ensure that all regulatory changes are } \\
\text { instituted in a timely manner and that all affected parties are } \\
\text { appropriately consulted in the development. }\end{array}$ \\
\hline 2 - Supervisor & $\begin{array}{l}\text { The SFC's operational independence should be strengthened } \\
\text { by strengthening processes around the appointment, } \\
\text { performance assessment and dismissal of the Superintendent. } \\
\text { Establishment of a fixed term of appointment (e.g. five to } \\
\text { seven years) might be considered in this regard. } \\
\text { In addition, consideration should be given to the balance of } \\
\text { authority between the Ministry and the SFC in the oversight of } \\
\text { the insurance sector. Greater thought should be given to } \\
\text { making decree requirements with respect to technical areas } \\
\text { less prescriptive and more principle based, or minimum } \\
\text { threshold based, and to empowering the SFC to establish and } \\
\text { manage the technical details. } \\
\text { Improved protection for staff from lawsuits for actions taken in } \\
\text { good faith should be given a high priority and implemented as } \\
\text { soon as possible. Strong protection is necessary if staff are to } \\
\text { move toward a risk based supervisory approach that requires } \\
\text { the exercise of greater judgment than compliance oriented } \\
\text { supervisory frameworks. }\end{array}$ \\
\hline $\begin{array}{l}3 \text { - Information Exchange and } \\
\text { Confidentiality Requirements }\end{array}$ & $\begin{array}{l}\text { Establishment of additional information sharing MOUs would } \\
\text { be beneficial to the SFC. It should also be encouraged to sign } \\
\text { the IAIS Multilateral Memorandum of Understanding. }\end{array}$ \\
\hline 4 - Licensing & $\begin{array}{l}\text { Establishing a definition of insurance business in the law may } \\
\text { help to address licensing issues associated with "near } \\
\text { insurance" products. } \\
\text { Granting of licenses with conditions or limitations might be } \\
\text { considered as a way of increasing market participation without } \\
\text { endangering the protection of consumers. }\end{array}$ \\
\hline 5 - Suitability of Persons & $\begin{array}{l}\text { Establishment of minimal competency requirements for } \\
\text { director and officer positions should be considered. }\end{array}$ \\
\hline $\begin{array}{l}6 \text { - Changes in Control and Portfolio } \\
\text { Transfers }\end{array}$ & None. \\
\hline 7 - Corporate Governance & $\begin{array}{l}\text { Board training, explicit minimum competency requirements } \\
\text { and the development of best practices with respect to board } \\
\text { governance and enterprise risk management should be } \\
\text { considered as a means of improving the functioning of boards. } \\
\text { The industry association might play an active role in such } \\
\text { work. Greater interaction (e.g. more frequent meets) between } \\
\text { the Superintendent and insurer boards through the }\end{array}$ \\
\hline
\end{tabular}




\begin{tabular}{|c|c|}
\hline Insurance Core Principle & Recommendations \\
\hline & $\begin{array}{l}\text { supervisory process has also been suggested as a means } \\
\text { which can improve the level of board conduct. } \\
\text { Internal auditors are said to sometimes have numerous } \\
\text { responsibilities in addition to the conduct of audits. This should } \\
\text { be confirmed and if true, corrected. Adding additional } \\
\text { responsibilities to internal audit can compromise its ability to } \\
\text { be an effective internal control. }\end{array}$ \\
\hline $\begin{array}{l}8 \text { - Risk Management and Internal } \\
\text { Controls }\end{array}$ & $\begin{array}{l}\text { Development of an actuarial function as an internal control to } \\
\text { advise the board and senior management is recommended. } \\
\text { More attention needs to be paid to potential asset liability } \\
\text { mismatch issues. }\end{array}$ \\
\hline 9 - Supervisory Review and Reporting & $\begin{array}{l}\text { Policies and procedures of the framework should be } \\
\text { developed, refined and documented. } \\
\text { Peer review systems and guidance regarding significant } \\
\text { activities, basic risk categories and evaluation of internal } \\
\text { controls should be established. } \\
\text { The two insurance pilot projects to facilitate implementation } \\
\text { need to be completed. } \\
\text { Some reorganization of the supervisory departments to focus } \\
\text { on the entity being regulated rather than risk category should } \\
\text { be considered. } \\
\text { Increased legal protection for staff exercising their authority in } \\
\text { good faith and increased ability to establish technical } \\
\text { requirements (see ICP 2) may also aid implementation of the } \\
\text { framework. }\end{array}$ \\
\hline 10 -Preventive and Corrective Measures & None. \\
\hline 11 -Enforcement & $\begin{array}{l}\text { Ways to shorten the time frame between sanction and final } \\
\text { decision (after appeal) should be considered. }\end{array}$ \\
\hline 12 -Winding-up and Exit from the Market & $\begin{array}{l}\text { Consideration should be given establishing a priority for policy } \\
\text { holder claims over other claims in a liquidation event. } \\
\text { In addition, establishment of an industry based policy holder } \\
\text { protection scheme should be considered to ensure minimal } \\
\text { levels of protection for claimants in the event of a liquidation } \\
\text { Finally, a review of the capital level at which an insurer must } \\
\text { be passed to FOGAFIN for liquidation should be undertaken. }\end{array}$ \\
\hline $\begin{array}{l}13 \text { - Reinsurance and Other Forms of Risk } \\
\text { Transfer }\end{array}$ & None \\
\hline 14 - Valuation & $\begin{array}{l}\text { The new reserving decree and the transition to IFRS are } \\
\text { significant opportunities to improve reserving practices and the } \\
\text { system of asset valuation and to build fuller compliance with }\end{array}$ \\
\hline
\end{tabular}




\begin{tabular}{|c|c|}
\hline Insurance Core Principle & Recommendations \\
\hline & $\begin{array}{l}\text { the standards of the core principle. They should be } \\
\text { implemented as soon as possible. }\end{array}$ \\
\hline 15 - Investment & $\begin{array}{l}\text { The SFC should consider further specific requirements with } \\
\text { respect to liquidity of investments. } \\
\text { In addition as markets evolve and the industry develops, it } \\
\text { may wish to consider broadening investment category limits } \\
\text { and establishing a less compliance oriented approach to } \\
\text { investments (e.g. prudent person approach, approval of } \\
\text { investment policy and broader investment categories). }\end{array}$ \\
\hline $\begin{array}{l}16 \text { - Enterprise Risk Management for } \\
\text { Solvency Purposes }\end{array}$ & $\begin{array}{l}\text { Over time the SFC should establish more comprehensive } \\
\text { enterprise risk management requirements that ensure insurers } \\
\text { are managing all relevant and material risks, consistent with } \\
\text { the standards under ICP } 16 \text {. } \\
\text { The SFC should also actively supervise the efforts of insurers } \\
\text { in this area, to help ensure that their capabilities are evolving } \\
\text { at an appropriate pace. Changes in this area will likely take } \\
\text { time to implement and will depend on development of other } \\
\text { components of the regulatory framework and of the insurance } \\
\text { marketplace. }\end{array}$ \\
\hline 17 - Capital Adequacy & $\begin{array}{l}\text { The SFC is encouraged to further develop its capital } \\
\text { requirements, particularly with respect to operational risk. } \\
\text { It is recommended that the SFC continue its cautious } \\
\text { approach with respect to the use of internal models due to } \\
\text { their complexity and until there is greater experience with } \\
\text { them both Colombia and internationally. } \\
\text { All capital requirements are at the legal entity level, to } \\
\text { enhance supervision, the introduction of capital requirements } \\
\text { at the group level should be considered. }\end{array}$ \\
\hline 18 - Intermediaries & $\begin{array}{l}\text { Establishing better and stronger regulatory requirements for } \\
\text { insurance intermediaries should be considered a high priority. } \\
\text { Some of these requirements should include a basic } \\
\text { licensing/registration system for insurance agents, a code of } \\
\text { conduct of conduct, basic suitability requirements and } \\
\text { minimum educational standards for insurance agents, and the } \\
\text { establishment of a public database on those agents who have } \\
\text { been formally disciplined for actions in the conduct of } \\
\text { insurance business or disqualified from registration. } \\
\text { Establishment of a self regulatory organization for agents, with } \\
\text { appropriate SFC oversight, should be considered as a } \\
\text { potential delivery vehicle. }\end{array}$ \\
\hline 19 -Conduct of Business & $\begin{array}{l}\text { The insurance market is currently incorporating a large } \\
\text { number of first time consumers. Consideration should be } \\
\text { given to ensuring that products like micro insurance are } \\
\text { appropriately regulated from a market conduct perspective. }\end{array}$ \\
\hline
\end{tabular}




\begin{tabular}{|c|c|}
\hline Insurance Core Principle & Recommendations \\
\hline 20 -Public Disclosure & $\begin{array}{l}\text { As the supervisory framework becomes more risk based and } \\
\text { as enterprise risk management improves in institutions, } \\
\text { greater disclosure of information on insurer risk, governance } \\
\text { and ERM should be required. }\end{array}$ \\
\hline 21 -Countering Fraud in Insurance & $\begin{array}{l}\text { Establishment of a joint SFC/industry fraud strategy would } \\
\text { proactively ensure that the risk of fraud is reduced across the } \\
\text { sector over time. }\end{array}$ \\
\hline $\begin{array}{l}22 \text { - Anti-Money Laundering and } \\
\text { Combating the Financing of Terrorism }\end{array}$ & $\begin{array}{l}\text { Resources for this program area should be reviewed to ensure } \\
\text { they are adequate. }\end{array}$ \\
\hline 23 -Group-wide Supervision & $\begin{array}{l}\text { The market is dominated by insurers belonging to large } \\
\text { corporate groups. However the supervision of large } \\
\text { conglomerates does not extend to all relevant entities. The } \\
\text { missing picture of the whole group limits the effectiveness of } \\
\text { group wide supervision. } \\
\text { The powers of the SFC should be increased to ensure that it } \\
\text { can properly address group supervision issues to at least the } \\
\text { financial holding company level (e.g. consolidated risk } \\
\text { management and financial reporting). }\end{array}$ \\
\hline $\begin{array}{l}24 \text { - Macro-prudential Surveillance and } \\
\text { Insurance Supervision }\end{array}$ & $\begin{array}{l}\text { The SFC should be encouraged to continue developing its } \\
\text { macro prudential surveillance framework, particularly with } \\
\text { regard to the role of the CCSSF and the identification of } \\
\text { emerging risks for insurance institutions. It should also move } \\
\text { forward with assessing the systemic importance of insurers. }\end{array}$ \\
\hline $\begin{array}{l}25 \text { - Supervisory Cooperation and } \\
\text { Coordination }\end{array}$ & $\begin{array}{l}\text { Increased monitoring and participation in the activities of the } \\
\text { IAIS by the SFC may be of benefit to the regulator and the } \\
\text { industry. }\end{array}$ \\
\hline $\begin{array}{l}26 \text { - Cross-border Cooperation and } \\
\text { Coordination on Crisis Management }\end{array}$ & $\begin{array}{l}\text { The SFC should be encouraged to complete its plans for } \\
\text { dealing with insurers in crisis and ensure that it has the tools } \\
\text { needed to carry out such plans. It should ensure that the plans } \\
\text { are internationally coordinated by working with foreign } \\
\text { supervisors, for example, through supervisory colleges. In } \\
\text { order to be effective it also needs to strengthen its } \\
\text { requirements around group supervision. }\end{array}$ \\
\hline
\end{tabular}

\section{E. Authorities' Comments}

180. The mission made note of advances made in the past five years in the insurance sector with respect to regulation and supervision as well as the SFC's clear vision for its supervisory work.

181. The report emphasizes the need for broader consultation of the industry at the time regulations are issued. In regard to this point, it is important to mention that pursuant to quality policies and to achieve the vision and missions of the MHCP and the SFC, over five years ago 
both authorities committed to publishing proposed regulations for public comment. Also, the SFC's integrated management system establishes a group of activities to take into account in designing, developing, and revising regulatory texts, and included among them is the presentation of the aforementioned solutions for public comment. In this regard, in developing any new regulations for insurance entities, the SFC conducts consultations with the parties involved as to the impact and content of proposed regulations.

182. In regard to governance of boards of directors and the suitability of its members, it should be noted that the SFC functions include the appointment and swearing in of directors, administrators, legal representatives, auditors, and others.

183. One of the requirements to be met by the above officials in order to be appointed is to provide the SFC with information on their education, professional and employment experience, and other aspects of their background. Based on this information and additional information requested, the SFC determines whether an individual is competent to fulfill the position for which he is applying.

184. In addition, External Circular (CE) 38 of 2009 (directives concerning review and adaptation of the internal control system) establishes that members of boards of directors have primary responsibility for corporate governance and must therefore act with professionalism, integrity, competence, and independence. It also defines a number of responsibilities including defining the entity's strategy, performance, and internal control system.

185. In the same way, it establishes that all components of the internal control system must be appropriate to the organization's size (in terms, inter alia, of number of employees, value of assets and revenue, funds received from the public, number of branch offices or agencies) and the nature of its activities and corporate purpose.

186. The SFC, in turn, has established a set of recommendations for corporate governance based on best international practices. These include the composition of the board of directors, the establishment of certain committees, the professional and personal profiles of board members, reporting to the shareholders' meeting, and other aspects. All of the recommendations serve as the criteria by which the supervisor conducts a full evaluation of the corporate governance and issues any recommendations he deems relevant.

187. In regard to consolidated supervision, Colombian law (Financial System Founding Law (EOSF), Article 53) provides that persons requesting licenses must submit all information on the beneficial owners of capital, both at the time of applying for a license and thereafter at any point during the life of the financial entity. The regulations also provide a clear definition of beneficial owner (Decree 2555 of 2010, Article 6.1.1.3).

188. In turn, if a financial entity is registered with the stock exchange, it is required to disclose its 20 principal shareholders to the market (CE 02 of 2001, second chapter, section 
2, issued by the former Superintendency of the Securities), which it does through the Securities Market Information System (SIMEV) administered by the SFC.

189. Also, the SFC's quality certified processes establish the express requirement that applicants for licenses provide complete information about the beneficial owners of the entity's capital (checklist provided for that purpose and published on the SFC website).

190. The SFC rules (the Basic Accounting and Financial Circular, CBCF) establish the obligation for insurers to submit quarterly reports on their shareholding structure, identifying shareholders owning 1 percent or more of the capital, up to the third level of ownership. This standard far exceeds those of other Latin American countries.

191. Given the importance of identifying the beneficial owners and the effects of ownership on several of the principles examined, a supervision exercise has been developed which identifies and evaluates the shareholding structure, capital structure, and beneficial ownership of the entity in question. The same exercise was conducted for the evaluation of banks. In practice, in the process of constitution as well as trading of shares, the SFC investigates the beneficial owner, and for this reason the identification of the beneficial owners is a requirement on the checklists. These processes also provide for the identification of operations that result in the acquisition of or change in control of the entity. 